UNIVERSIDADE DE BRASÍLIA

INSTITUTO DE CIÊNCIAS BIOLÓGICAS

DEPARTAMENTO DE FITOPATOLOGIA

PROGRAMA DE PÓS-GRADUAÇÃO EM FITOPATOLOGIA

OCORRÊNCIA E DIVERSIDADE DE Pythium E Phytophthora EM FONTES DE ÁGUA UTILIZADA PARA IRRIGAÇÃO NA REGIÃO DO DISTRITO FEDERAL.

Elenice Alves Barboza

Brasília-DF 


\section{OCORRÊNCIA E DIVERSIDADE DE Pythium E Phytophthora EM FONTES DE ÁGUA UTILIZADA PARA IRRIGAÇÃO NA REGIÃO DO DISTRITO FEDERAL.}

Dissertação apresentada à
Universidade de Brasília como
requisito parcial para a obtenção do
título de Mestre em Fitopatologia pelo
Programa de Pós-graduação em
Fitopatologia.

\section{Orientador}

Helson Mario Martins do Vale

\section{Co-orientador}

Ailton Reis

Brasília-DF 


\section{FICHA CATALOGRÁFICA}

Barboza, Elenice Alves.

Ocorrência e diversidade de Pythium e Phytophthora em fontes de água utilizada para irrigação na região do Distrito Federal./Elenice Alves Barboza. Brasília, 2014.

$$
\text { p. 135:il. }
$$

Dissertação de mestrado. Programa de Pós-graduação em Fitopatologia, Universidade de Brasília, Brasília.

I. ecologia aquática, caracterização, filogenia, oomicetos, Solanum lycopersicum L.

II. Universidade de Brasília. PPG/FIT

III. Ocorrência e diversidade de Pythium e Phytophthora em fontes de água utilizada para irrigação na região do Distrito Federal. 
Aos meus queridos pais, Francisco e Francisca

e à minha tia Alzira, pelo amor, carinho e incentivo prestados durante todos os momentos da minha vida.

Dedico. 


\section{Agradecimentos}

A Deus, em primeiro lugar, pelo dom da vida, pela sabedoria e perseverança para superar os momentos difíceis.

Aos meus pais, Francisco e Francisca, pelo apoio e carinho dedicados durante toda minha vida. À minha querida tia Alzira pela compreensão, pelas palavras de amparo e conforto nas horas de angústia e pelo amor que sempre demonstrou. $\mathrm{E}$ a todos os meus familiares que são a base da minha vida, por me encorajarem a continuar estudando e por compartilharem comigo cada passo dessa trajetória.

Aos meus orientadores, Dr. Helson Mario Martins do Vale e Dr. Ailton Reis, pelos preciosos conselhos, pela confiança e pelos conhecimentos transmitidos que foram essenciais à conclusão desse trabalho.

Ao Dr. Antônio Williams Moita pelo importante auxilio nas análises estatísticas.

Às minhas amigas Cléia e Rayane, pelos momentos de alegria, pela amizade e por terem sido fundamentais na consecução de cada etapa deste trabalho.

Aos amigos Maurício e Geisianny pelas dicas e pela paciência interminável nas explicações que me ajudaram a desvendar o mundo da Biologia Molecular.

Ao meu namorado, Bruno, pelo companheirismo, pela inestimável ajuda nas coletas, por aguentar os momentos de desânimo e estresse e por ter permanecido sempre ao meu lado fazendo parte, mais do que qualquer pessoa, dessa conquista.

Aos amigos do departamento de Fitopatologia, Geane, Carina, João, Ricardo, Josefa, Josiane, Rafaela, Mônica, Carol, Pedro e Larissa por tornarem as aulas do curso mais alegres, por dividirem comigo as horas de estudo e de tensão pré-provas e pela ajuda mútua durante todo o mestrado.

A Érica que sempre se mostrou disponível a me ajudar, e à Nancy, que tornou as aulas práticas de Nematologia muito mais prazerosas.

Ao Dr. Jadir e à Daniele por permitirem o uso dos equipamentos e do espaço do Laboratório de Nematologia da Embrapa Hortaliças.

Aos colegas e técnicos do Laboratório de Fitopatologia da Embrapa Hortaliças, Wagner, Luana, Fabiana, Amanda, Fred, Danilo, Celma e Aracele pela assistência durante todos esses meses, pela valiosa troca de experiência e pelos momentos agradáveis que tornaram essa jornada menos tediosa.

Ao CNPq pela concessão da bolsa que permitiu a realização deste trabalho. 
Trabalho realizado junto ao Departamento de Fitopatologia do Instituto de Ciências Biológicas da Universidade de Brasília, sob orientação do Professor Helson Mario Martins do Vale, com apoio do CNPq.

\title{
OCORRÊNCIA E DIVERSIDADE DE Pythium E Phytophthora EM FONTES DE ÁGUA UTILIZADA PARA IRRIGAÇÃO NA REGIÃO DO DISTRITO FEDERAL.
}

\author{
ELENICE ALVES BARBOZA
}

DISSERTAÇÃO APROVADA em _____ por:

Prof. Adalberto C. Café Filho

Examinador (membro interno)
Dra. Mariana Rodrigues Fontenelle Examinador (membro externo)
$\overline{\text { Prof. Helson Mario Martins do Vale }}$ Orientador

\begin{tabular}{c}
\hline Dr. Ailton Reis \\
Co-Orientador \\
\\
BRASÍLIA - DISTRITO FEDERAL \\
BRASIL \\
$\mathbf{2 0 1 4}$
\end{tabular}




\section{SUMÁRIO}

LISTA DE TABELAS

Página
i

LISTA DE FIGURAS .................................................................. ii

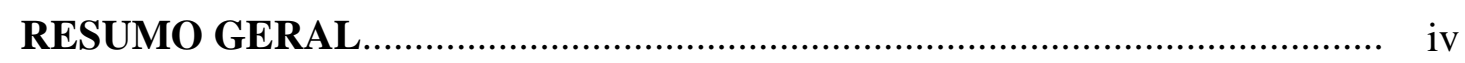

GENERAL ABSTRACT ......................................................................... vi

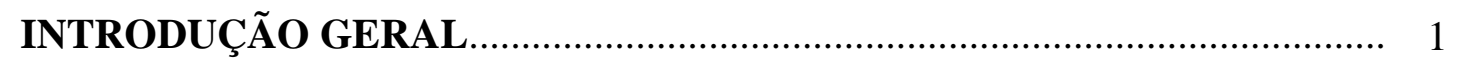

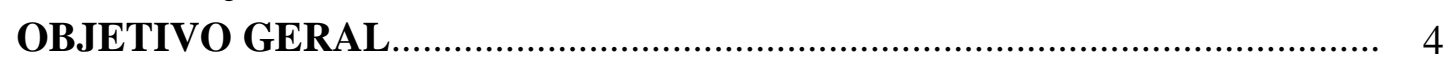

OBJETIVOS ESPECÍFICOS .............................................................. 4

REVISÃO DE LITERATURA ........................................................... 5

A cultura do tomateiro................................................................................... 5

Classificação e importância econômica da Classe Oomycetes................................. 7

O gênero Pythium ........................................................................................... 9

O gênero Phytophthora..................................................................................... 11

Ocorrência e disseminação de Pythium e Phytophthora ....................................... 13

Caracterização morfológica e molecular de Pythium e Phytophthora ..................... 16

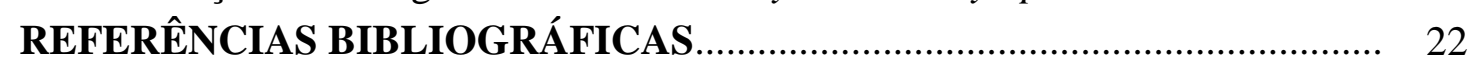

CAPÍTULO 1: Avaliação de folhas largas e estreitas como iscas para a detecção de oomicetos em córregos, represas e reservatórios de água.

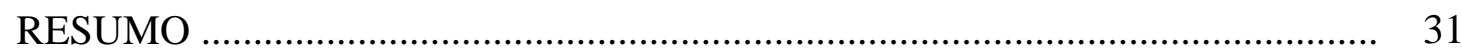

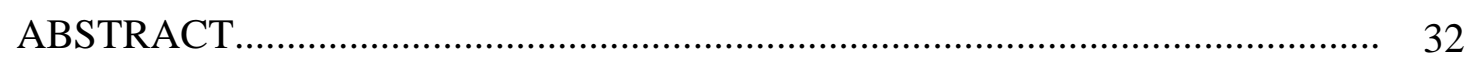

1. INTRODUÇÃ O .................................................................................... 33

2. MATERIAL E MÉTODOS ................................................................... 38

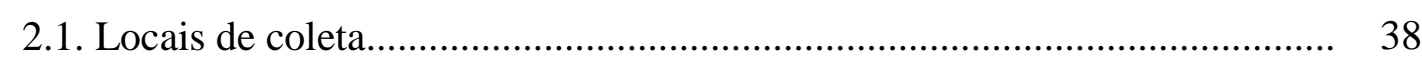

2.2. Preparo das iscas e isolamento em meio de cultura.................................... 41

2.3. Avaliação dos fatores abióticos............................................................. 44

2.4. Delineamento experimental e análise dos dados...................................... 44

3. RESULTADOS E DISCUSSÃO.............................................................. 46

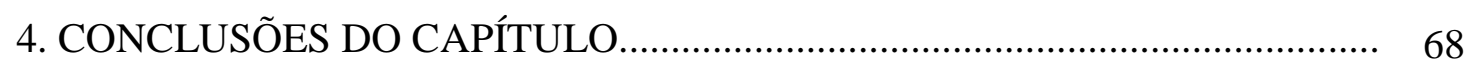

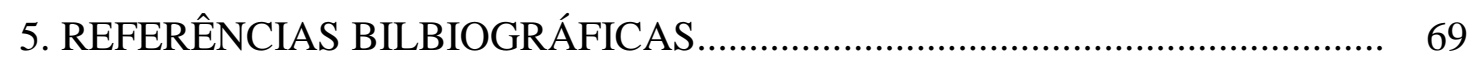

CAPÍTULO 2: Caracterização morfológica e molecular dos isolados de Pythium e Phytophthora obtidos em fontes de água de irrigação...................................... 74

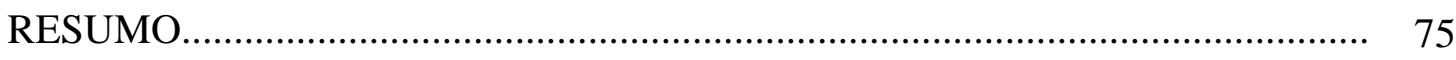

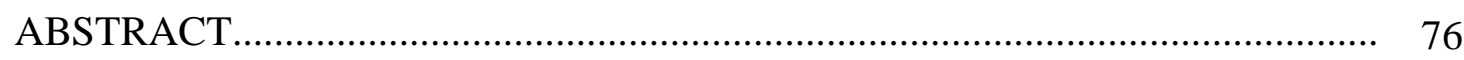

1. INTRODUÇÃ

2. MATERIAL E MÉTODOS....................................................................... 81 
2.1. Caracterização molecular......................................................................... 81

2.2.1. Extração de DNA ...................................................................... 81

2.2.2. Amplificação por PCR da região ITS do rDNA.................................. 82

2.2.3. Análise Filogenética....................................................................... 83

2.2. Caracterização morfológica........................................................................ 83

2.3. Teste de patogenicidade em frutos............................................................... 84

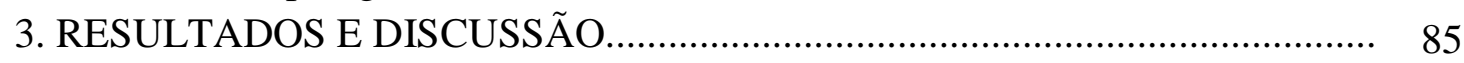

4. CONCLUSÕES DO CAPÍTULO............................................................... 112

5. REFERÊNCIAS BIBLIOGRÁFICAS............................................................... 113

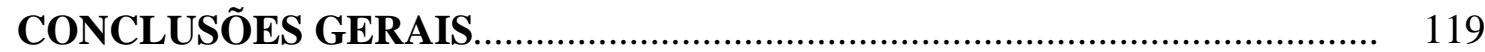




\section{LISTA DE TABELAS}

CAPÍTUlO 1: Avaliação de folhas largas e estreitas como iscas para a detecção de oomicetos em córregos, represas e reservatórios de água.

Tabela 1. Fatores abióticos analisados em cada amostragem realizada entre setembro/2013 a agosto/2014.....

Tabela 2. Frequência de detecção (\%) de Phytophthora spp. e Pythium spp em cada local de coleta

Tabela 3. Frequência de detecção (\%) de Phytophthora spp. e Pythium spp em cada mês de coleta.

Tabela 4. Frequência de detecção (\%) de Phytophthora spp. e Pythium spp em cada espécie vegetal utilizada como isca

CAPÍTULO 2: Caracterização morfológica e molecular dos isolados de Pythium e Phytophthora obtidos em fontes de água de irrigação.

Tabela 5. Identificação, local e mês de coleta e espécie vegetal utilizada como isca para a detecção dos isolados de Pythium spp. recuperados das fontes de água entre 2013 e 2014

Tabela 6. Identificação, local e mês de coleta e espécie vegetal utilizada como isca para a detecção dos isolados de Phythophthora spp. recuperados das fontes de água entre 2013 e 2014.

Tabela 7. Características morfológicas dos isolados encontrados em fontes de água entre 2013 e 2014.

Tabela 8. Incidência da doença (\%) em frutos de tomate observada em 2, 3 e 4 dias após a inoculação (DAI) em dois experimentos. 


\section{LISTA DE FIGURAS}

Figura 1. Esquema dos três genes do rDNA e regiões de espaçamento interno (ITS) e intergênicas (IGS), e as setas representam primers universais que amplificam regiões codificantes e não codificantes (White et al., 1990).

CAPÍTULO 1: Avaliação de folhas largas e estreitas como iscas para a detecção de oomicetos em córregos, represas e reservatórios de água.

Figura 2. Locais de amostragem utilizados no estudo

Figura 3. Isolamento das folhas utilizadas como iscas em placas de Petri contendo meio V8-ágar seletivo.

Figura 4. Frequência de detecção (\%) de Phytophthora e Pythium durante os meses de coleta nos meios de cultura BARPN e BARPNH

Figura 5. Frequência de isolamento de Phytophthora spp. no meio BARPN e BARPNH em cada local de amostragem durante os meses avaliados (Interação: local x mês).

Figura 6. Frequência de isolamento de Pythium spp. no meio BARPN e BARPNH em cada local de amostragem durante os meses avaliados (Interação: local $\mathrm{x}$ mês).

Figura 7. Frequência de isolamento de Phytophthora spp. (\%) no meio BARPN em cada local de coleta e a variação nos fatores abióticos, temperatura, $\mathrm{pH}$ e absorbância entre os meses de setembro/2013 a agosto/2014.

Figura 8. Frequência de isolamento de Pythium spp. (\%) no meio BARPN em cada local de coleta e a variação nos fatores abióticos, temperatura, $\mathrm{pH}$ e absorbância entre os meses de setembro/2013 a agosto/2014.

Figura 9. Frequência de isolamento de Phytophthora spp. no meio BARPN e BARPNH nas espécies vegetais utilizadas como isca em cada local de coleta 
Figura 10. Frequência de isolamento de Pythium spp. no meio BARPN e BAPRNH nas espécies vegetais utilizadas como isca em cada local de coleta (Interação: local x isca)

Figura 11. Frequência de isolamento de Phytophthora spp. no meio BARPN e BARPNH nas espécies vegetais utilizadas como isca em cada mês de coleta (Interação: mês x isca).

Figura 12. Frequência de isolamento de Pythium spp. no meio BARPN e BARPNH nas espécies vegetais utilizadas como isca em cada mês avaliado (Interação: mês $\mathrm{x}$ isca)

CAPÍTULO 2: Caracterização morfológica e molecular dos isolados de Pythium e Phytophthora obtidos em fontes de água de irrigação.

Figura 13. Amplificação da região ITS e 5.8S do rDNA dos isolados de Pythium spp. e Phytophthora spp. utilizando os primers ITS4 e ITS5.

Figura 14. Árvore filogenética, construída com sequências dos isolados de Pythium spp., baseada na análise da região ITS1, 5.8S e ITS2 do rDNA obtida pelo método Neighbour-joining.

Figura 15. Árvore filogenética, construída com sequências dos isolados de Phytophthora spp., baseada na análise da região ITS1, 5.8S e ITS2 do rDNA obtida pelo método Neighbour-joining. 101

Figura 16. Estruturas morfológicas de Pythium spp 105

Figura 17. Estrutras morfológicas de Phytophthora spp 107 


\section{BARBOZA, Elenice Alves. OCORRÊNCIA E DIVERSIDADE DE Pythium E}

Phytophthora EM FONTES DE ÁGUA UTILIZADA PARA IRRIGAÇÃO NA REGIÃO DO DISTRITO FEDERAL. 2014. Dissertação (Mestrado em Fitopatologia) Universidade de Brasília, Brasília, DF.

A irrigação é um insumo indispensável para a produção de alimentos durante grande parte do ano. Entretanto, a fonte de água utilizada pode carregar propágulos de patógenos que causam doenças em plantas cultivadas. Entre os microrganismos que frequentemente são isolados de ambientes aquáticos, destacam-se os representantes do Filo Oomycota, incluindo espécies de fitopatógenos dos gêneros Pythium e Phytophthora. A detecção e o monitoramento dessas espécies tornou-se um passo chave para o manejo de doenças de plantas, principalmente em países que reciclam a água da irrigação. No Brasil, ainda é muito incipiente o conhecimento sobre a diversidade e os aspectos ecológicos de Pythium spp. e Phytopthora spp. em ecossistemas aquáticos, assim como a disponibilidade de métodos práticos e acessíveis para a detecção das espécies na água. Desta forma, na primeira etapa deste estudo foram avaliadas folhas de diferentes espécies vegetais como iscas para Pythium e Phytophthora em fontes de água usada para irrigação de tomateiro. A patogenicidade dos isolados obtidos foi testada em frutos de tomate verdes. Em todos os locais de coleta e meses foi possível o isolamento de Pythium e Phytophthora da água por meio da utilização de iscas, no entanto a frequência de isolamento variou entre os locais e entre os meses de amostragem. A maior frequência de detecção de Phytophthora foi observada no reservatório do Sítio Cachoeira e no Córrego Capoeira Grande em todos os meses, exceto em setembro em que a frequência foi maior na nascente do Sítio Cachoeira. Para Pythium, houve diferença entre os locis e os meses de coleta dependendo do meio de cultura, com uma menor frequência de detecção no meio BARPNH. A maior frequência de isolamento foi observada no córrego do Roncador e no córrego Capoeira Grande, nos meios de cultura 
BAPRN e BARPNH, respectivamente. As folhas de tomateiro permitiram uma alta frquência de detecção, independente do local e mês de coleta, e foi considerada promissora como iscas para Pythium e Phytophthora em ambientes aquáticos. Folhas de capim elefante também possibilitaram alta recuperação de isolados de Pythium da água, assim como folhas de manga para Phytophthora. Por fim, os isolados obtidos das fontes de água foram caracterizados por meio da observação dos caracteres morfológicos e do sequenciamento da região ITS1, 5.8S e ITS2 do rDNA. Como resultado, foi possível identificar sete espécies diferentes, das quais cinco pertenciam ao gênero Pythium e duas, ao gênero Phytophthora. A análise filogenética demonstrou que as espécies de Pythium foram separadas de acordo com a morfologia dos esporângios, assim, $P$. helicoides e $P$. chamaihyphon, que possuem esporângios globosos, permaneceram no mesmo clado, enquanto as espécies $P$. catenulatum, P. myriotylum e P. graminicola, com esporângios filamentosos, permaneceram em um clado separado. Todas as espécies de Phytophthora foram incluídas no clado 9, de acordo com a análise das sequências da região ITS, que engloba várias espécies encontradas em ambientes aquáticos. No teste de patogenicidade, apenas para o isolado de $P$. helicoides foi comprovadamente patogênico, causando podridão de frutos em todas as repetições no segundo dia após a inoculação. Os isolados de Phytophthora não se mostram patogênicos à frutos de tomate. Os resultados observados para os demais isolados foram menos conclusivos devido à maior diferença entre os experimentos conduzidos em diferentes épocas. Dessa forma, foi possível recuperar espécies de fitopatógenos de fontes de água de irrigação por meio do uso de folhas, sendo que as folhas de tomateiro se apresentaram como eficientes iscas para os dois gêneros testados.

Palavras-chave: ecologia aquática, caracterização, filogenia, oomicetos, Solanum lycopersicum L. 
BARBOZA, Elenice Alves. OCCURRENCE AND DIVERSITY OF Pythium AND Phytophthora IN WATER SOURCES USED FOR IRRIGATION IN THE REGION OF THE DISTRITO FEDERAL. 2014. Dissertation (Master in Plant Pathology) Universidade de Brasília, Brasília, DF, Brazil.

Irrigation is an essential input for the agricultural yeld year round. However, the source of water used for it can carry propagules of pathogens that cause disease in cultivated plants. Among the microorganisms that are frequently isolated from aquatic environments, the representatives of the Phylum Oomycota stand out, including plant pathogen species of the genus Pythium and Phytophthora. The detection and monitoring of these species has become a key step for the management of plant diseases, mainly where irrigation water is recycled. In Brazil, knowledge about the diversity and ecological aspects of Pythium spp. and Phytopthora spp. in aquatic ecosystems is incipient, as well as the availability of practical and affordable methods for the detection of species in water. Thus, in the first stage of this study, leaves of different plant species were tested as bait for Pythium and Phytophthora monitoring in water souces used for irrigation of tomato. The pathogenicity of the obtained oomycete isolates was tested on green tomato fruits. In all sampling places and months it was possible to isolate Pythium and Phytophthora of the water through the use of baits, however the frequency of isolation ranged among the sampling spots and among sampling months. The highest frequency of detection of Phytophthora was observed in the Sítio Cachoeira reservoir and the Capoeira Grande stream in every month, except in september when the isolation rate was highest in the Sítio Cachoeira headspring. For Pythium, there were differences between sampling sites and months depending on the culture medium, with a lowest detection frequency in the BARPNH medium. The highest frequency of isolation was observed in the Roncador stream and Capoeira Grande stream, in the BAPRN and BARPNH culture media, respectively. The tomato leaves enabled a high detection 
frequency, independent of location and sampling month, and its considered promising as a specie bait for Pythium and Phytophthora in aquatic environments. Napier grass leaves also enabled high recovery of isolates of Pythium from water, as well as mango leaves to Phytophthora. Finally, isolates obtained from water sources were characterized by morphological characters and sequencing of the ITS1, 5.8S e ITS2 region of the rDNA. As a result, seven different species, five from the genus Pythium and two from the genus Phytophthora, were identified. Phylogenetic analysis showed that Pythium species were clustered according to the morphology of the sporangia, thus, $P$. helicodes and $P$. chamaihyphon, that have globose sporangia were grouped in the same clade, while $P$. catenulatum, P. myriotylum and P. graminicola species, with filamentous sporangia, remained in a separate clade. All Phytophthora species were included in the clade 9, according to the sequences of the ITS region, that includes several species found in aquatic environments. In the pathogenicity tests, only the strain of $P$. helicoides was proven pathogenic, causing rotting of fruits in every replications on the second day after inoculation. Isolates of Phytophthora not show pathogenic to tomato fruits. The results observed for the remaining isolates were less conclusive due to a big difference between the experiments conducted at different times. Thus, it was possible to recover plant pathogens species of water sources of irrigation by using leaves, being the tomato leaves presented to be effective baits for the two genera tested.

Keywords: aquatic ecology, characterization, oomycetes, phylogeny, Solanum lycopersicum L. 


\section{INTRODUÇÃO GERAL}

A Região Centro-Oeste é um dos principais polos produtores de tomate de mesa e para processamento industrial do Brasil. A expansão da cultura no Centro-Oeste e os elevados índices de produtividade são consequências das características edafoclimáticas da região, que favorecem o cultivo de tomate, e dos altos investimentos em tecnologia, como o emprego de materiais genéticos de maior potencial produtivo e a diversidade de insumos utilizados (de Melo \& Vilela, 2005; Clemente \& Boiteux, 2012).

Durante a estação seca do ano, o cultivo de tomate nos estados de Goiás e Distrito Federal é viabilizado pelo uso da agricultura irrigada (Coutinho, 2000). Em muitos casos, as fontes de água utilizadas na irrigação podem abrigar diversas espécies de microrganismos (Thomson \& Allen, 1974; Shokes \& McCarter, 1979; Hong \& Moorman, 2005). Algumas das espécies encontradas em ecossistemas aquáticos sobrevivem saprobiamente em partículas vegetais e animais presentes na água, sendo responsáveis pela degradação de substratos orgânicos (Hudson, 1986; Voronin, 2008). Contudo, existem espécies, habitantes de fontes de água, descritas como agentes causais de doenças em plantas (Hong \& Moorman, 2005).

Baker \& Matkin (1978) constataram que a maioria dos microrganismos encontrados em água pertence aos Filos Chytridiomycota e Oomycota, grupos que abrigam várias espécies fitopatogênicas. Esses microrganismos produzem estruturas adaptadas a ambientes aquáticos, como zoósporos flagelados que apresentam mobilidade e podem ser disseminados a distâncias consideráveis (Sparrow, 1960). Assim, as fontes de água infestadas com propágulos desses patógenos de plantas atuam, em muitos casos, como fonte de inóculo para diversas culturas, e possuem implicações na disseminação para áreas livres de doenças 
(Pittis \& Colhoun, 1984; Macdonald et al., 1994; Oudemans, 1999; Bush, 2002; Sutton et al., 2009).

Levantamentos da diversidade da microbiota aquática demonstram que espécies de Phytophthora e Pythium, importantes fitopatógenos de diversas plantas cultivadas, são muito abundantes na água, mas a sua ecologia ainda é pouco conhecida (Gill, 1970; Bush et al., 2003; Hong \& Moorman, 2005; Voronin, 2008, Reeser et al., 2011). A distribuição desses oomicetos em córregos, reservatórios e represas pode ser influenciada por diferentes fatores abióticos tais como temperatura, $\mathrm{pH}$, concentração de sais, entre outras (Sparrow, 1960; Dangles et al., 2004; Kiziewicz et al., 2006; Prasad et al., 2009). Devido à capacidade de locomoção dos zoósporos, a ocorrência de Pythium e Phytophthora em determinados pontos também é modificada, alterando a chance de detecção de seus propágulos (Sparrow, 1960).

Desta forma, o emprego de métodos que permitam uma maior abrangência na detecção de patógenos em fontes de água pode ser uma ferramenta importante para elucidar os fatores que controlam a distribuição de espécies de oomicetos na água. Em outros países, diversas técnicas têm sido aplicadas com o objetivo de se conhecer as espécies de Pythium e Phytophthora em ambientes aquáticos. O uso de filtros, a amostragem da água, o uso de diferentes materiais como iscas e a utilização de métodos bioquímicos e moleculares, como ensaio com antissoro e realização de PCR são técnicas bastante utilizadas para o monitoramento de oomicetos. Esses métodos podem apresentar vantagens e limitações ao seu uso (Sanchez et al., 2000; Hong et al., 2002; Themann et al., 2002; Bush, 2002; Hong \& Moormam, 2005).

Diversas espécies de Pythium e Phytophthora já foram encontradas em ambientes aquáticos, porém os isolados obtidos ainda apresentam-se pouco caracterizados (Reeser et al., 2011). Muitas vezes, a presença de isolados de espécies reconhecidamente 
fitopatogênicas na água encoraja uma associação precoce com o isolado encontrado em plantas doentes, porém existem poucos trabalhos comprovando a importância econômica de água contaminada com fitopatógenos para a agricultura (Hong \& Moorman, 2005). Nos últimos anos, a identificação e caracterização a partir da análise do DNA desses isolados permitiu um entendimento maior sobre a diversidade existente em um ecossistema e sobre o real risco de contaminação existente na água utilizada. O conhecimento dessas espécies aquáticas pode auxiliar também o esclarecimento sobre os aspectos relacionados à sobrevivência e à dispersão de fitopatógenos em áreas agrícolas.

Apesar de vários estudos sobre a presença e a identidade de oomicetos em água de irrigação terem sido desenvolvidos na Europa e na América do Norte (Thomson \& Allen, 1974, Macdonald et al., 1994; Von Broembsen \& Wilson, 1998; Bush, 2002; Themann et al., 2002; Bush et al., 2003), no Brasil, o monitoramento desses microrganismos em ambientes aquáticos ainda é muito raro. A maioria dos trabalhos voltados à detecção e caracterização de espécies zoospóricas concentram-se em áreas nativas no Sudeste do país (Milanez, 1968; Milanez, 1970; Gomes et al., 2003, Baptista et al., 2004; Miranda \& PiresZottarelli, 2008; Gomes \& Pires-Zottarelli, 2006, 2008; Nascimento et al., 2011, 2012), existindo poucos trabalhos avaliando o potencial de fontes de água de irrigação em abrigar espécies fitopatogênicas. 


\section{OBJETIVO GERAL}

O objetivo deste trabalho foi investigar a ocorrência de espécies de Pythium e Phytophthora em fontes de água de irrigação de tomateiro nos estados de Goiás e Distrito Federal e compreender os aspectos ecológicos e filogenéticos da distribuição desses oomicetos.

\section{OBJETIVOS ESPECÍFICOS}

1. Estudar a ocorrência e a flutuação populacional de espécies de Pythium e Phytophthora em fontes de água de irrigação de tomate;

2. Analisar o efeito de diferentes fatores abióticos sobre a diversidade e a taxa de isolamento das espécies de Pythium e Phytophthora presentes na água;

3. Avaliar o potencial de folhas de diferentes espécies vegetais como iscas para a detecção de Pythium e Phytophthora em córregos, represas e reservatórios de água;

4. Realizar caracterização morfológica e molecular dos isolados obtidos;

5. Avaliar a relação filogenética, a partir de sequências da região ITS do DNA ribossômico, entre os isolados de Pythium e Phytophthora presentes em ambientes aquáticos;

6. Testar a patogenicidade dos isolados obtidos em fontes de água de irrigação 


\section{REVISÃO DE LITERATURA}

\section{A cultura do tomateiro}

O tomate (Solanum lycopersicum L.) pertence à família Solanaceae, que engloba outras hortaliças de importância econômica, como a batata (Solanum tuberosum L.), o pimentão (Capsicum annuum L.) e a berinjela (Solanum melongena L.). A planta apresenta caule flexível e abundante ramificação lateral que determina a incapacidade de sustentar o peso dos frutos, determinando sua forma natural de moita (Filgueira, 2007). Desta forma, o cultivo do tomate é realizado de duas maneiras distintas de acordo com o seu hábito de crescimento: estaqueado ou tutorado para plantas que possuem o hábito de crescimento indeterminado e que podem atingir mais de 2,5 m de altura, e hábito determinado para o tomate rasteiro que ocorre principalmente nas cultivares que tem como finalidade o processamento industrial (Alvarenga, 2004).

O tomateiro tem como centro de origem a região limitada pela Cordilheira do Andes, o norte do Chile e o sul do Equador. A espécie cultivada, S. lycopersicum (sin.: Lycopersicon esculentum Mill.) é proveniente da espécie andina silvestre, L. esculentum var. cerasiforme, que produz frutos do tipo cereja. A domesticação e melhoramento do tomate foram iniciados pelasa civilizações pré-colombianas que ocupavam o território onde atualmente encontra-se o México, e após a colonização espanhola deste país, a cultura foi levada à Europa em meados do século XVI (Alvarenga, 2004; Filgueira, 2007).

Introduzido no Brasil no final do século XIX por meio de imigrantes europeus, o tomate tornou-se a segunda hortaliça em importância econômica, sendo produzido em praticamente todos os estados brasileiros (Paula Júnior \& Venzon, 2007). As principais regiões produtoras de tomate são as regiões Centro-Oeste e Sudeste, destacando-se os 
estados de Goiás, São Paulo e Minas Gerais, que juntos produziram mais de 2,5 milhões de toneladas, aproximadamente $65 \%$ da produção nacional na safra de 2013 . A maior área cultivada com tomate está localizada no estado de Goiás, aproximadamente 16 mil ha, com uma produtividade em torno de 84 mil toneladas/ha, superior à média nacional que é de 66,15 mil toneladas/ha. Já o Distrito Federal possui uma produção de 61.754 toneladas distribuída em uma área de 925 ha (IBGE, 2014).

Vários obstáculos tornam a tomaticultura uma atividade de alto risco (Lopes \& Ávila, 2005; Filgueira, 2007). Durante seu ciclo produtivo, a cultura pode ser acometida por diversas doenças que reduzem a produtividade e alteram a qualidade dos frutos. O tomateiro é suscetível ao ataque de vários fitopatógenos como vírus, nematoides, bactérias, fungos e oomicetos que podem limitar seu cultivo em algumas épocas e em determinadas regiões pela ausência de controle eficaz ou pela elevação do custo de produção com o emprego de medidas de controle (Lopes et al., 2005).

Dentre os patógenos que atacam a cultura do tomate, espécies de Phytophthora causam sérios prejuízos. P. infestans (Mont.) de Bary é o agente causal de uma das principais doenças do tomateiro, conhecida como requeima ou mela. Toda a parte aérea da planta pode ser afetada, sendo que em ataques severos ocorre perda total da lavoura, especialmente se as condições climáticas, como temperatura amena e alta umidade, forem observadas (Lopes et al., 2005; Reis, 2010). O gênero Phytophthora possui ainda espécies que sobrevivem no solo, como $P$. capsici e $P$. nicotianae, que causam podridão radicular, podridões de frutos e tombamento de mudas, podendo ocasionar falhas no estande, seja por morte da semente ou da radícula da emergência (damping-off de pré-emergência), ou morte de plântulas (damping-off de pós-emergência) de tomateiro (Mendes et al., 1998; Reis et al., 2007). Esses sintomas também podem ser notados em decorrência do ataque de outros patógenos que incluem espécie do gênero Pythium Pringsheim (Lopes et al., 2005). Esses 
dois gêneros, comumente encontrados atacando mudas estão, na maioria dos casos, associados a solos ou substratos contaminados. Outra forma de introdução e disseminação destes microrganismos em uma lavoura é a agua contaminada utilizada na irrigação. Neher e Duniway (1992) comprovaram que propágulos da espécie Phytophthora nicotiane (P. parasitica) foram disseminados a longas distâncias do ponto inicial de infestação por meio dos sulcos de irrigação em campos de tomateiro. Da mesma forma, Café-Filho \& Duniway (1995) testaram a disseminação de Phytophthora capsici e Phytophthora nicotiane (P. parasitica) a partir de pontos previamente infestados em campos de tomateiro, abóbora e pimentão. A observação do aumento de infecções em frutos com o aumento da distância da fonte de inóculo confirmou a disseminação de $P$. capsici e $P$. nicotianae pela água da irrigação, ocorrendo também o acúmulo de inóculo secundário em razão da frequência de irrigação.

\section{Classificação e importância econômica da Classe Oomycetes}

Pertencente ao Reino Chromista, Filo Oomycota, a Classe Oomycetes compreende 13 Ordens que incluem organismos presentes em diferentes ecossistemas (Kirk et al., 2008). No entanto, a taxonomia desse grupo sofreu diversas mudanças ao longo dos anos. O avanço proporcionado pelo uso de técnicas moleculares colaborou com o sistema de classificação e permitiu estudos taxonômicos mais aprofundados a partir de análise de sequenciamento de genes do DNA nuclear e mitocondrial (Fry \& Grünwald, 2010; Moreira, 2010).

Até a década de 90, o Reino Fungi agrupava todos os organismos conhecidos como fungos, porém a classificação filogenética e a condição polifilética das espécies corroboraram com a separação em três Reinos distintos: Fungi, Chromista e Protista. Desta forma, os membros da Classe Oomycetes, anteriormente conhecidos como fungos 
zoósporicos, ou water molds (mofos aquáticos), foram situados fora do Reino Fungi e agrupados no Reino Chromista, juntamente com algas marrons e diatomáceas. Dentro do Reino Fungi foram incluídos apenas os denominados fungos verdadeiros que são microrganismos relacionados filogeneticamente (Alexopoulos et al., 1996; Cavalier- Smith, 1998; Kirk et al., 2008; Fry \& Grünwald, 2010).

Assim como os fungos verdadeiros, os oomicetos apresentam crescimento micelial, nutrição por absorção e reprodução via esporos (Fry \& Grünwald, 2010). No entanto, diversas características estruturais e bioquímicas reforçaram essa reclassificação dos oomicetos em um Reino distinto, tais como: composição da parede celular, constituída de celulose e $\beta$ glucanas, e não de quitina, componente principal da parede celular fúngica; presença de hifas asseptadas, formando um micélio cenocítico e cristas mitocondriais tubulares. Na reprodução assexual são formados zoósporos diploides e biflagelados, com um flagelo liso e mais curto, do tipo chicote, e outro do tipo "tinsel" com mastigonemas. O talo assimilativo também se apresenta na condição diploide (Alexopoulos, 1996; Amorim et al., 2011).

A formação dos gametângios feminino e masculino, chamados oogônio e anterídio, respectivamente, ocorrem durante a reprodução sexual. A reprodução sexual inclui meiose gametangial, transformando os núcleos diploides em haploides (Fry \& Grünwald, 2010). A plasmogamia ocorre com a passagem dos núcleos do anterídio para o interior do oogônio por meio de tubo de fertilização. Com o pareamento dos núcleos ocorre a cariogamia, originando o oósporo, esporo de repouso diploide (Amorim et al., 2011).

Os organismos da Classe Oomycetes são cosmopolitas, podendo habitar ambientes aquáticos, marinhos e continentais. Compreendem espécies que vivem saprofiticamente em detritos vegetais e animais e outras espécies consideradas parasitas de algas, peixes, plantas e mamíferos, incluindo o homem (Alexopoulos, 1996). Várias doenças de plantas são 
causadas por oomicetos, sendo as espécies de maior importância encontradas nas Ordens Saprolegniales, Albuginales e Peronosporales (Fry \& Grünwald, 2010). As Ordens Saprolegniales e Albuginales possuem apenas um o gênero descrito como fitopatógeno: Aphanomyces, agente causal de podridões de raízes em plantas anuais, e Albugo, que causa ferrugem branca em plantas hortícolas (Agrios, 2005; Amorim et al., 2011).

A Ordem Peronosporales engloba as principais espécies de patógenos de plantas da Classe Oomycetes. Esse grupo inclui parasitas obrigatórios de plantas que causam doenças conhecidas como míldios. Várias espécies estão associadas a essa doença, porém os gêneros mais comuns são Bremia, Peronospora, Pseudoperonospora, Plasmopara e Sclerospora que causam míldio em diferentes espécies vegetais e distinguem-se morfologicamente pela variação na ramificação do esporangióforo em cada gênero (Amorim et al., 2011).

Na Ordem Peronosporales encontram-se ainda os gêneros Phytophthora e Pythium, que abrangem importantes patógenos de plantas. As espécies incluídas nesses dois gêneros desenvolvem-se nos mais diferentes ambientes e atacam uma gama muito grande de hospedeiras. Com exceção de algumas espécies de Phytophthora, os representantes desses dois gêneros são considerados típicos habitantes de solo, mas podem produzir estruturas adaptadas a ambientes aquáticos e apresentar resistência às baixas concentrações de oxigênio (Sparrow, 1960; Erwin \& Ribeiro, 1996; Agrios, 2005; Amorim et al., 2011).

\section{O gênero Pythium}

Espécies do gênero Pythium estão entre os patógenos de solo mais comuns e são considerados importantes agentes etiológicos de doenças de plantas, sendo constantemente associados a podridões de sementes, tombamento de mudas, podridão radicular e podridão de tecidos vegetais carnosos em contato com o solo. As perdas causadas variam muito com a 
umidade do solo, temperatura e outros fatores, mas frequentemente as mudas são totalmente destruídas ou morrem logo após serem transplantadas em solos infestados (Shokes \& McCarter, 1979; Agrios, 2005; Amorim et al., 2011; Schroeder et al., 2013).

Segundo Lévesque \& de Cock (2004), 106 espécies de Pythium são reconhecidas e validadas, porém mais de 300 espécies foram propostas, muitas com a identidade ainda incerta (Schoeder et al., 2013; Index fungorum, 2014). As espécies fitopatogênicas mais importantes incluem $P$. ultimum, $P$ aphanidermatum, $P$. irregulare e $P$. myriotylum (Trigiano et al., 2004).

Na ausência do hospedeiro, Pythium spp. sobrevive saprofiticamente em restos culturais ou permanece em dormência através dos oósporos ou clamidósporos. Sob condições favoráveis, o oósporo germina, produzindo esporângios do qual o citoplasma flui para formar uma vesícula, local em que os zoósporos serão diferenciados. Os zoósporos possuem a habilidade de nadar em filmes de água entre as partículas de solo e são atraídos por exsudatos do hospedeiro (Amorim et al., 2011; Schoeder et al., 2013).

Pythium spp. apresenta alta adaptação a ambientes aquáticos e pode ser disseminado através da água de irrigação, situação corriqueira em casas de vegetação, viveiros e sistemas de produção hidropônicos (Hong \& Moorman, 2005; Schoeder et al., 2013). Várias espécies de Pythium têm sido relatadas em fontes de água, sendo as mais comuns $P$. acanthicum Drechesler, $P$. catenulatum Matthews, $P$. dissocotum Drechesler, $P$. inflatum Matthews, $P$. paroecandrum Drechesler, P. rostratum Butler, P. vexans de Bary, P. ultimum Trow, P. myriotylum Drechesler, P. graminicola Subramaniam, P. spinosum Sawada, P. irregulare Buisman, P. aphanidermatum (Edson) Fitzp e P. middletonii Sparrow (Bewley \& Buddin, 1920; Gill, 1970; Shokes \& McCarter, 1979; Jenkins \& Averre, 1983; Pittis \& Colhoun, 1984; Thinggaard \& Middelboe, 1989; MacDonald et al., 1994; Sanchez \& Gallego, 2000; Shrestha et al., 2013). 


\section{O gênero Phytophthora}

O gênero Phytophthora de Bary tornou-se um dos gêneros mais conhecidos e estudados devido à sua importância histórica como patógeno de plantas. A primeira espécie identificada foi $P$. infestans, agente causal da requeima do tomate e da batata. Essa doença foi relatada inicialmente na Europa durante o século XIX e sua importância se deve às consequências desastrosas que provocou, causando destruição das plantações de batata na Irlanda e sendo responsável pela morte de milhões de pessoas. A partir dos trabalhos de Henrich Anton de Bary, considerado pioneiro da Fitopatologia, foi possível a associação da requeima com a atuação deste oomiceto (Agrios, 2005; Blum et. al., 2012)

Desde a descoberta do gênero Phytophthora em meados do século XIX, mais de 100 espécies já foram descritas (Kroon et al., 2012), tornando-se um dos maiores gêneros dentro da Família Peronosporaceae (Lamour, 2013) O aumento no número de espécies se deve principalmente ao desenvolvimento de ferramentas mais eficazes na separação e definição das espécies. Entre as décadas de 70 e 80 houve uma significativa contribuição para o conhecimento do gênero, incluindo aspectos sobre fisiologia, taxonomia, genética, técnicas de isolamento e indução da reprodução sexual e assexual (Erwin \& Ribeiro, 1996; Lamour, 2013). A partir da década de 90, a introdução de ferramentas moleculares proporcionou mais um avanço na identificação e taxonomia das diferentes espécies de Phytophthora (Forster et al., 1990; Cooke et al., 2000; Martin et al., 2012).

Phytophthora constitui-se em importante patógeno de plantas e possui uma ampla gama de hospedeiros, encontrando-se distribuída por todo o mundo (Erwin \& Ribeiro, 1996). Numerosos sintomas se desenvolvem após a infecção por Phytophthora spp., como tombamento de mudas, podridões de raízes, necrose em órgãos da parte aérea das plantas, podridões de frutos, queima em folhas e ramos jovens (Agrios, 2004; Lamour, 2013). 
O ciclo de vida de Phytophthora é muito semelhante ao das espécies de Pythium, porém os zoósporos são diferenciados diretamente no esporângio e não na vesícula como neste último. Além disso, no gênero Pythium os esporangióforos são idênticos às hifas assimilativas, enquanto em Phytophthora os esporangióforos são diferenciados e ramificamse simpodialmente (Trigiano et al., 2004; Amorim et al., 2011).

As espécies de Phytophthora podem ser homotálicas, quando a reprodução sexual ocorre em culturas únicas, ou heterotálicas, necessitando de talos diferentes, em que cada um representa um grupo de compatibilidade distinto designado A1 ou A2. As espécies podem produzir tambem estruturas de sobrevivência como oósporos, esporângios e clamidósporos e possuírem uma rápida evolução, originando novas raças e apresentando a habilidade de produzir espécies híbridas (Lamour, 2013). Estas características tornam o controle de Phytophthora spp. ainda mais difícil. Assim, a eficiência da aplicação de medidas de controle antes do estabelecimento e disseminação do patógeno em qualquer cultura depende muito do monitoramento das espécies, que é uma das primeiras etapas para o manejo de doenças de plantas (Amorim et al., 2011).

O desenvolvimento de técnicas de isolamento em ambientes naturais e agrícolas tem favorecido a descrição de novas espécies de Phytophthora. Com o aprimoramento dos métodos utilizados, esse grupo de fitopatógenos tem sido mais facilmente detectado (Martin et al., 2012; Lamour, 2013). Em fontes de água, por exemplo, mais de 30 espécies de Phytophthora já foram relatadas em diferentes regiões (Zappia et al., 2014), incluindo $P$. cactorum (Lebert \& Cohn) J. Schröt., P. cambivora (Petri) Buisman, P. capsici Leonian, P. cinnamomi Rands, P. citricola Sawada, P. citrophthora (R.E. Sm. \& E.H. Sm.) Leonian, P. gonapodyides (Petersen) Buisman, P. megasperma Drechsler, P. nicotianae Breda de Haan, P. drechsleri tucker, P. ramorum Werres, De Cock \& Man e P. syringae (Kleb.) Kleb., além de alguns táxons ainda informais e outras espécies que ocorrem naturalmente na água como 
P. litoralis Jung, P. lateralis Tucker \& Milbrath, P. lacustris Brasier, Cacciola, Nechwatal, Jung \& Bakonyi , P. insolita Ann \& W.H. Ko, P. siskiyouensis Reeser \& E.M. Hansen , P irrigata C. Hong \& M. Gallegly e P. hydrophatica C. Hong \& M. Gallegly (Bewley \& Buddin, 1921; Pittis \& Colhoun, 1984; Von Broembsen, 1984; MacDonald et al., 1994; Hansen \& Delatour, 1999; Themann et al., 2002; Brasier et al., 2003; Bush et al., 2003; Hong et al., 2008; Sutton et al., 2009; Hong et al., 2010; Reeser et al., 2011; Hüberli et al., 2013).

\section{Ocorrência e disseminação de Pythium e Phytophthora em água de irrigação}

A água é considerada insumo indispensável para produção de alimentos, principalmente em países como o Brasil, onde ocorre uma distribuição irregular de chuvas durante o ano (Aldaz, 1971). As áreas irrigadas são responsáveis pelo suprimento de 30 a 40\% do alimento produzido no mundo (Federico, 2005). No entanto, a água de córregos, lagos, represas e reservatórios utilizados na irrigação podem conter microrganismos capazes de causar doenças em plantas cultivadas. Estes fitopatógenos podem ser habitantes naturais de ambientes aquáticos ou serem oriundos do solo adjacente à fonte de água (Zappia et al., 2014). O escoamento de água da chuva ou da irrigação que entra em contato com plantas doentes no campo ou carrega partículas de solo infestadas também pode contribuir para a diversidade de fitopatógenos encontrados na água (Hong \& Moorman, 2005).

A composição populacional de Pythium e Phytophthora na água é afetada por muitos fatores abióticos e bióticos (Prasad et al., 2009). A compreensão sobre a influência das condições ambientais, como $\mathrm{pH}$, temperatura, concentração de sais, entre outros sobre a sobrevivência destes fitopatógenos pode auxiliar na estimativa do risco de epidemias e na escolha do momento ideal para adoção de medidas de controle, pois a sobrevivência e a 
disseminação de fitopatógenos em ecossistemas aquáticos, em muitos casos, tem relação estreita com a ocorrência de doenças em plantas (Zappia et al., 2014).

Desde as primeiras décadas do século passado, Bewley \& Buddin (1921) associaram o tombamento de mudas de tomate à presença de Phytophthora cryptogea na água, detectada por meio da técnica de filtração da água e o uso de meio não seletivo para o isolamento desses microrganismos. Desde o trabalho de Bewley \& Buddin (1921), diversos métodos de detecção de fitopatógenos na água foram desenvolvidos e otimizados ao longo dos anos.

Técnicas de isolamento por meio da amostragem da água e filtração também são uma alternativa para determinar a presença de Pythium e Phytophthora em diferentes locais. Themann et al. (2002) relataram a ocorrência de diversas espécies de Phytophthora, entre estas, $P$. cinnamomi, $P$. cryptogea, $P$. drechsleri e $P$. ramorum, por meio de amostras de água de contêineres que abasteciam viveiros. De maneira semelhante, Bush et al. (2003) constataram a presença de várias espécies de Pythium e Phytophthora em amostras de efluentes de viveiros que foram filtrados, sendo o filtro posteriormente plaqueado em meio seletivo. Em contrapartida, o uso de amostras de água pode não ser representativo da diversidade de oomicetos aquáticos, já que algumas espécies não estão uniformemente distribuídas em fontes de água. Além disso, o tempo de filtração e o tipo de malha utilizada podem interferir na recuperação das espécies. Para contornar essa limitação é necessário um maior número de amostras e um tempo maior para seu processamento, o que torna o método laborioso (Hong \& Moorman, 2005).

Recentemente, o desenvolvimento de métodos moleculares e bioquímicos vem proporcionando maior praticidade e rapidez ao monitoramento de fitopatógenos na água. Em alguns estudos, a utilização de PCR multiplex e o método de ELISA foram suficientes para relatar a presença de Pythium spp. e Phytophthora spp., permitindo a detecção de 
propágulos, mesmo em baixa concentração (MacDonald et al., 1994; Winton \& Hansen, 2001; Themann et al., 2002). No entanto, o uso de antissoros pode não ser eficiente no levantamento de diferentes espécies de oomicetos na água, podendo ainda gerar falsos negativos. Além disso, a reação pode ser influenciada pelas características químicas e físicas da água, como materiais orgânicos e concentração de sais das amostras (von Broembsen \& Deacon, 1997; Themann \& Werres, 1997; Themann et al., 2002).

Na década de 70, Rooney \& Mcnight (1972), testaram a eficiência de diferentes materiais como iscas. Eles escolheram 14 diferentes substratos entre galhos, folhas e frutas de várias espécies vegetais, além de materiais de queratina e quitinosos, como cabelo e exúvia de insetos, e conseguiram relatar a presença de 34 espécies de fungos zoósporicos e oomicetos na água do Lago Lyli em Utah. Da mesma forma, Sutton et al. (2009) demonstraram a eficiência do uso de folhas como iscas para o monitoramento de Phytophthora ramorum em 84 córregos localizados na floresta de Oregon, Estados Unidos.

A utilização de folhas como iscas apresenta um grande potencial para a descoberta de Pythium spp. e Phytophthora spp. em fontes de água. O tecido vegetal permite a germinação dos zoósporos e o crescimento micelial em seu interior, possibilitando a sobrevivência das espécies até o isolamento em laboratório (Bush et al., 2003). Ademais, zoósporos móveis possuem quimiotaxia positiva e movimentam-se em direção à superfície foliar (Carlile, 1985), permitindo uma maior correlação entre as espécies obtidas e a diversidade existente no local de estudo.

A ocorrência de Phytophthora e Pythium na água tem sido amplamente estudada, porém a maior parte dos trabalhos se concentra em países da Europa e nos Estados Unidos (Shokes \& McCarter, 1979; Hansen \& Delatour, 1999; Themann et al., 2002; Sutton et al., 2009; Reeser et al., 2011), em que existe a preocupação com a reutilização da água de 
irrigação. Poucos estudos envolvendo a presença de oomicetos na água de ecossistemas tropicais têm sido desenvolvidos.

No Brasil, a presença de oomicetos na água foi relatada em meados do século passado (Joffily, 1947), porém a maioria dos estudos subsequentes concentra-se nos Biomas Mata Atlântica e Cerrado dos estados de São Paulo e Minas Gerais, principalmente em ambientes naturais, com reduzida influência antrópica (Milanez, 1968; Milanez, 1970; Gomes et al., 2003, Baptista et al., 2004; Miranda \& Pires-Zottarelli, 2008; Gomes \& PiresZottarelli, 2006, 2008; Nascimento et al., 2011, 2012).

Apesar de poucas informações a respeito da utilização de água contaminada com fitopatógenos na irrigação de plantas cultivadas, Freitas et al. (2001b) e Carlos et al. (2001) provaram a existência de patógenos de plantas dos gêneros Pythium, Phytophthora, Rhizoctonia e Fusarium em reservatório de água utilizada para irrigação no Distrito Federal. Freitas et al. (2001a) atribuíram a ocorrência de tombamento de plântulas de diversas espécies vegetais à utilização de água contaminada com fitopatógenos, sendo que o aumento da concentração de propágulos deveu-se principalmente à passagem da água de irrigação em áreas com atividade agrícola. Ainda assim, o conhecimento sobre a diversidade e os fatores que afetam a ocorrência desses microrganismos em fontes de água de irrigação ainda é muito escasso na região Centro-Oeste do país, especialmente quando se trata de fitopatógenos, como Pythium e Phytophthora.

\section{Caracterização morfológica e molecular de Pythium e Phytophthora}

A identificação das espécies de Pythium e Phytophthora tem sido realizada tradicionalmente com base na morfologia das estruturas assexuais e sexuais. A observação da morfologia dos esporângios e dos oogônios é uma das principais maneiras de diferenciar 
as espécies (Lee \& Taylor, 1992). Outras características como o preenchimento do oogônio pelo oósporo, tipo de anterídio, compatibilidade sexual, presença de clamidósporos, entre outros caracteres também são considerados na distinção entre espécies (Waterhouse, 1968, 1970; Erwin \& Ribeiro, 1996; Schroeder et al., 2013). Mais recentemente, outros critérios passaram a ser usados na taxonomia e classificação das espécies como a gama de hospedeiros, temperatura de crescimento e características culturais (Schroeder et al., 2013).

Muitas vezes, a identificação de um isolado ao nível de espécie requer um árduo trabalho e muito tempo de treinamento. A sobreposição e alta variabilidade de diversos atributos morfológicos na identificação das espécies dificultam e tornam laboriosa a separação correta dos táxons, principalmente quando se trata da descrição de espécies novas. Além disso, a similaridade morfológica entre espécies nem sempre refletem suas relações evolutivas (Crawford et al., 1996; Erwin \& Ribeiro, 1996; Cooke et al., 2000; kroon et al., 2012).

Nos últimos anos, a identificação das espécies baseada em métodos bioquímicos e moleculares tornou possível a conciliação dos caracteres morfológicos com as informações genéticas de cada organismo. O sequenciamento do DNA impulsionou o conhecimento sobre as espécies de Phytophthora e Pythium e permitiu uma melhor separação de espécies relacionadas (Cooke et al. 2000; Lévesque \& de Cock, 2004; Kroon et al., 2012; Schoeder et al., 2013).

Com o surgimento da Reação em Cadeia da Polimerase (PCR) na década de 80, um grande avanço no campo da taxonomia e diagnose de fitopatógenos foi observado. Essa técnica baseia-se na síntese de milhões de cópias de um segmento específico de DNA e consiste em ciclos repetitivos de desnaturação, hibridização e extensão (Mullis \& Faloona, 1987). 
Sequências específicas de DNA geradas através da PCR têm subsidiado a classificação e a análise filogenética de diversas espécies. Para as espécies de Pythium e Phytophthora, a análise de sequências das regiões do DNA nuclear e mitocondrial está entre as principais ferramentas para caracterização desses dois grupos. Os genes que codificam para proteínas metabólicas ou estruturais tais como a citocromo oxidase II (cox II) e a $\beta$ tubulina tem se mostrado útil em estudos evolutivos para estes gêneros (Bruns et al., 1991).

O gene da citocromo oxidase II codifica para uma enzima que catalisa o passo final na cadeia de transporte de elétrons, a transferência de um elétron do citocromo c para o oxigênio. O uso deste gene tem permitido a reconstrução das relações filogenéticas entre espécies de Pythium e Phytopthora por apresentar maior variabilidade que o DNA nuclear e permitir a comparação entre organismos semelhantes (Villa et al., 2006). Dessa forma, Martin (2000), analisou as relações filogenéticas de 24 espécies de Pythium a partir do sequenciamento do gene Cox II, revelando o agrupamento em clados que correspondiam à morfologia dos zoosporângios ou aos espessamentos de hifas. De maneira semelhante, Martin \& Tooley (2003) utilizaram as sequências dos genes cox I e cox II de 51 isolados de Phytophthora, porém as relações filogenéticas entre as 27 espécies estudadas para o gene Cox II não apresentaram conformidade com as características morfológicas, patogenicidade, gama de hospedeiras ou temperatura ótima para crescimento.

O sequenciamento do gene da $\beta$-tubulina também vem sendo empregado para demonstrar a relação filogenética entre espécies. Esse gene codifica para uma das famílias conservadas de tubulinas, os blocos constituintes dos microtubulos que fazem parte da constituição do citoesqueleto e flagelos das células eucarióticas (Thon and Royse, 1999). Na maioria das vezes os trabalhos de filogenia baseados no gene da $\beta$-tubulina para Pythium e Phytophthora são realizados em conjunto com outras regiões como ITS do rDNA e cox II (Martin \& Tooley, 2003; Kroon et al., 2004; Villa et al., 2006; Blair et al., 2008). 
O DNA ribossômico, que compreende genes que codificam o rRNA, tem se mostrado uma das regiões mais promissoras para esse tipo de estudo por acumularem mutações e permitirem a separação de espécies próximas. O rDNA é composto por genes dispostos nas subunidades $18 \mathrm{~S}-5.8 \mathrm{~S}-26 \mathrm{~S}$ e que se repetem ao longo do genoma, tornando a amplificação pela PCR mais fácil que as de outros loci que apresentam poucas cópias. Entre essas regiões codificadoras podem ser citados os Espaços Transcritos Internos (Internal transcribed spacer $=$ ITS), sendo as subunidades $18 \mathrm{~S}$ e $5.8 \mathrm{~S}$ separadas pela região ITS1 e a 5.8S e 28S separadas pela ITS2 (Figura 1). A presença de trechos conservados nas regiões codificadoras permitiu o desenho de iniciadores para PCR e tem permitido a separação de diversos táxons a partir da análise das sequências nucleotídicas da região ITS (White et al., 1990).

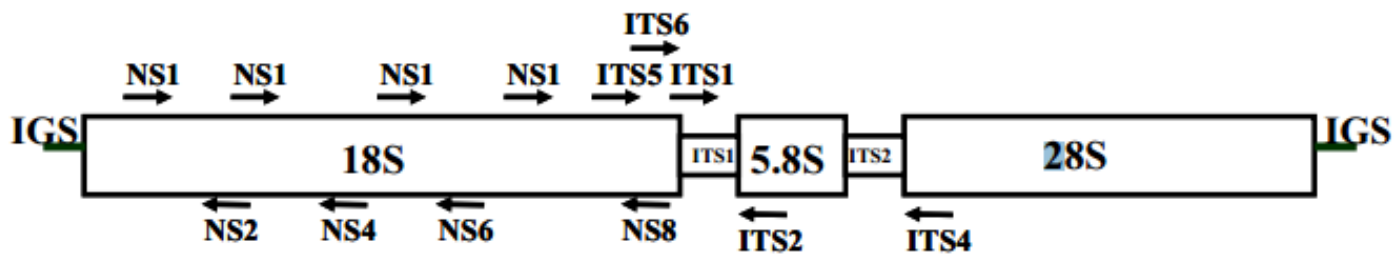

Figura 1. Esquema dos três genes do rDNA e regiões de espaçamento interno (ITS) e intergênicas (IGS), e as setas representam primers universais que amplificam regiões codificantes e não codificantes (White et al., 1990).

A popularidade da região ITS do rDNA em estudos de filogenia é notada pela quantidade de trabalhos publicados enfatizando a alta variabilidade encontrada nas sequências de diferentes espécies (Álvarez \& Wendel, 2003). Lee \& Taylor (1992) relataram a relação filogenética entre 27 isolados de cinco espécies de Phytophthora a partir da análise das sequências da região ITS1 e ITS2 do rDNA e demonstraram a estreita relação evolutiva entre $P$. capsici e $P$. citrophthora. Da mesma forma, Crawford et al. (1996) compararam as sequencias nucleotídicas da mesma região do rDNA de 15 espécies de Phytophthora, e 
constataram o agrupamento das espécies que apresentaram o mesmo tipo de esporângios (papilados, semi-papilados e não papilados). Alguns anos mais tarde, Cooke et al. (2000) publicaram um estudo extensivo utilizando 50 espécies de Phytophthora que formaram oito distintos clados, fornecendo a base para o conceito de clado utilizado dentro do gênero. Blair et al. (2008) realizaram um estudo utilizando mais de um locus do DNA nuclear, entre eles a região ITS. Neste trabalho, o gênero foi dividido em 10 clados diferentes que até hoje são utilizados em trabalhos de filogenia dentro do gênero.

Matsumoto et al. (1999) utilizaram as sequências da região ITS de 30 espécies de Pythium para construção de árvores filogenéticas utilizando dois grupos com diferentes tipos de esporângio. Como esperado, as espécies que apresentavam o mesmo tipo de esporângio estavam localizadas no mesmo clado. Lévesque \& de Cock (2004) analisaram a sequência da região ITS1 e ITS2 de 100 espécies de Pythium e verificaram uma alta heterogeneidade entre as espécies, agrupando-as em 11 clados distintos que confirmaram a origem monofilética das espécies que possuem o mesmo tipo de esporângio.

Muitos estudos dentros do gênero Pythium demonstraram a origem polifilética das espécies. Um dos exemplos disso é o trabalho realizado por Uzuhashi et al. (2010) que separou o gênero em cinco clados monofilétitos segundo a análise filogenética das regiões LSU do rDNA e CoII do mDNA. Consequentemente, o gênero foi dividido em quatro novos gêneros (Ovatisporangium, Globisporangium, Elongisporangium e Pilasporangium) e algumas espécies foram mantidas como Pythium. Alguns anos depois, a análise do rDNA e do mDNA demonstraram que o clado que agrupava as espécies de Pythium com esporângios globosos (Clado "K” de acordo com Lévesque \& de Cock (2004)), incluídas no gênero Ovatisporangium por Uzuhashi et al. (2010), era filogeneticamente mais próximo a Phytophthora que Pythium. Membros desse clado foram provisoriamente classificados como Phytopythium por estarem filogeneticamente e morfologicamente entre Pythium e 
Phytophthora (Bala et al., 2010;Uzuhashi et al., 2010; Robideau et al., 2011). As espécies de Phytopythium apresentam esporângios globosos a ovoides, com papila e proliferação interna, como ocorre dentro do gênero Phytophthora, e possuem a discarga de zoósporos semelhante à Pythium (Bala et al., 2010).

A análise de sequencias da região ITS apresenta diversas vantagens como a extensa base de dados disponíveis no GenBank, a disponibilidade de primers universais e a alta variabilidade que permite estudos filogenéticos entre espécies próximas (Álvarez \& Wendel, 2003). 


\section{REFERÊNCIAS BIBLIOGRÁFICAS}

AGRIOS, G.N. 2005. Plant Pathology. 5th ed. Academic Press. St Paul. 922p.

ALDAZ, L. 1971. Caracterização parcial do regime de chuvas do Brasil. DNM/CEM. 108 p

ALEXOPOUlOS, C.J.; MIMS, C.W. \& BLACKWELL, M. 1996. Phylum Oomycota. Introductory Mycology. New York: John Wiley \& Sons, $4^{\text {th }}$ ed. p. 683-737.

ALVARENGA, M.A.AR. (Ed.). 2004. Tomate: produção em campo, em casa-de-vegetação e em hidroponia. Lavras: Editora UFLA, 400p.

ÁLVAREZ I. \& WENDEL J.F. 2003. Ribosomal ITS sequences and plant phylogenetic inference. Molecular Phylogenetics and Evolution, 29(3): 417-434.

AMORIM, L.; REZENDE, J.A.M. \& BERGAMIN FILHO, A. (eds). 2011. Manual de Fitopatologia: Princípios e Conceitos. 4. ed. Volume 1. Piracicaba, SP: Ceres. 704p.

BAKER, K.F. \& MATKIN, O.A. 1978. Detection and control of pathogens in water. Ornamentals Northwest Newsletter, 2(2):12-13.

BALA, K.; ROBIDEAU, G.P.; LÉVESQUE, C.A., DE COCK, A.W.A.M; ABAD, Z.G.; LODHI, A.M.; SHAHZAD, S.; GHAFFAR, A.; COFFEY, M.D. 2010. Phytopythium Abad, de Cock, Bala, Robideau, Lodhi \& Lévesque, gen. nov. and Phytopythium sindhum Lodhi, Shahzad \& Lévesque, sp. nov. Persoonia 24, 136-137.

BAPTISTA, F.R.; PIRES-ZOTTARELLI, C.L.A.; ROCHA, M. \& MILANEZ, A.I. 2004. O gênero Pythium Pringsheim de áreas de cerrado no estado de São Paulo, Brasil. Revista Brasileira de Botânica 27(2): 281-290.

BEWLEY, W.F. \& BUDDIN, W. 1921. On the fungus flora of glasshouse water supplies in relation to plant diseases. Annals of Applied Biology. 8(1): 10-19.

BLAIR, J.E.; COFFEY, M.D.; PARK, S.Y.; GEISER, D.M. \& KANG, S. 2008. A multilocus phylogeny for Phytophthora utilizing markers derived from complete genome sequences. Fungal Genetics and Biology, 45(3): 266-277.

BLUM, L.E.B.; CARES, J.E.; UESUGI, C.H. \& VALE, H.M.M. (Eds) 2012. Fitopatologia e Microrganismos Fitopatogênicos. Brasília: Gráfica e Editora Positiva. 156 p.

BRASIER, C.M.; COOKE, D.E.L.; DUNCAN, J.M. \& HANSEN, E.M. 2003. Multiple new phenotypic taxa from trees and riparian ecosystems in Phytophthora gonapodyides $-P$. megasperma ITS Clade 6, which tend to be high-temperature tolerant and either inbreeding or sterile. Mycological Research 107: 277-90.

BRUNS, T.D.; WHITE, T.J. \& TAYLOR, J.W. 1991. Fungal molecular systematics. Annual Review of Ecology and Systematics, 22:525-564. 
BUSH, E.A. 2002. Characterization of Phytophthora species in recycled irrigation water at a container nursery in Southwestern Virginia. M. S. Thesis, Virginia Polytechnic Institute and State University, Blacksburg, VA.

BUSH, E.A.; HONG, C. \& STROMBERG, E. 2003. Fluctuations of Phytophthora and Pythium spp. in components of a recycling irrigation system. Plant Disease, 87(12): 15001506.

CAFÉ-FILHO, A.C. \& DUNIWAY, J.M. 1995. Dispersal of Phytophthora capsici and P. parasitica in furrow-irrigated rows of bell pepper, tomato and squash. Plant pathology, 44(6): 1025-1032.

CARLILE, M.J. 1985. The zoospore and its problems. In: Water, Fungi, and Plants. Eds. AYERS, P.G. \& BODDY, L. Cambridge University Press, Cambridge, London. pp. 105-118.

CARLOS, R.M.E.; NASSER, L.C.B.; LAMY, A.C.M. \& FREITAS, M.A. 2001. Influência da qualidade de sementes e da água de irrigação no sistema de produção de mudas de espécies floríferas no Distrito Federal. Anais, $19^{\circ}$ Encontro Nacional de Arborização Urbana, Brasília, DF.

CAVALIER-SMITH, T. 1998. A revised six-kingdom system of life. Biological Reviews, 73(3): 203-266.

CLEMENTE, F.M.V.T. \& BOITEUX, L.S. (eds). 2012. Produção de tomate para processamento industrial. Brasília: Embrapa Hortaliças. 344p.

COOKE, D.E.L.; DRENTH, A.; DUNCAN, J.M.; WAGELS, G. \& BRASIER, C. M. 2000. A molecular phylogeny of Phytophthora and related oomycetes. Fungal Genetics Biology. 30(1):17-32.

COUTINHO, L.M. 2000. Aspectos do Cerrado. http://eco.ib.usp.br/cerrado/aspectos_clima.htm. Consultado em: Agosto/2014

CRAWFORD, A.R.; BASSAM, B.J.; DRENTH, A.; MACLEAN, D.J. \& IRWIN, J.A.G. 1996. Evolutionary relationships among Phytophthora species deduced from rDNA sequence analysis. Mycological Research, 100(4): 437-443.

DANGLES, O.; GESSNER, M.O.; GUEROLD, F. \& CHAUVET, E. 2004. Impacts of stream acidification on litter breakdown: implications for assessing ecosystem functioning. Journal of Applied Ecology 41(2): 365 -378.

DE MELO, P.C.T. \& VILELA, N.J. 2005. Desafios e perspectivas para a cadeia brasileira do tomate para processamento industrial. Horticultura Brasileira, 23: 154-157.

ERWIN, D.C. \& RIBEIRO, O.K. 1996. Phytophthora Diseases Worldwide. APS Press, St. Paul, Minnesota.

FEDERICO, G. 2005. Feeding the world: an economic history of agriculture 1800-2000. Princeton University Press.

FILGUEIRA, F.A.R. 2007. Novo Manual de Olericultura: Agrotecnologia Moderna na Produção e Comercialização de Hortaliças. 3 Ed. Viçosa: MG. 421 p. 
FORSTER, H.; COFFEY, M.D.; ELLWOOD, H. \& SOGIN, M. L. 1995. Sequence analysis of the small subunit ribosomal RNAs of three zoosporic fungi and implications of fungal evolution. Mycologia 82: 306-312.

FREITAS, M.A.; CAFÉ FILHO, A.C. \& NASSER, L.C.B. 2001a. Qualidade da água de irrigação em um núcleo rural no Distrito Federal. Fitopatologia Brasileira 26:492. (Resumo).

FREITAS, M.A.; NASSER, L.C.B. \& CAFÉ FILHO, A.C. 2001b. Água contaminada: fitopatógenos infestam a água. Cultivar $H F, 8: 32-37$.

FRY, W.E. \& GRÜNWALD, N.J. 2010. Introduction to Oomycetes. The Plant Health Instructor.Doi:10.1094/PHI-I-2010-1207-1.

http://www.apsnet.org/edcenter/intropp/PathogenGroups/Pages/IntroOomycetes.aspx.

Consultado em: Agosto de 2014.

GILL, D. L. 1970. Pathogenic Pythium from irrigation ponds. Plant Disease Reporter, 54(120): 1077- 1079.

GOMES, A.L. \& PIRES-ZOTTARELLI, C.L.A. 2006. Diversidade de Oomycota da reserva Biológica de Paranapiacaba, Santo André, SP: primeiras citações para o Brasil. Revista Brasileira de Botânica 29(4): 569-567.

GOMES, A.L. \& PIRES-ZOTTARELLI, C.L.A. 2008. Oomycota (Straminipila) da Reserva Biológica de Paranapiacaba, Santo André, SP, Brasil. Acta Botanica Brasilica, 22(2): 373392.

GOMES, A.L.; PIRES-ZOTTARELLI, C.L.A.; ROCHA, M. \& MILANEZ, A.I. 2003. Saprolegniaceae de áreas de cerrado do estado de São Paulo, Brasil. Hoehnea, 30(2): 95110

HANSEN, E. \& DELATOUR, C. 1999: Phytophthora species in oak forests of north-east France. Annals of Forest Science, 56(7): 539-547

HONG, C.; RICHARDSON, P.A. \& KONG, P. 2002. Comparison of membrane filters as a tool for isolating Pythiaceous species from irrigation water. Phytopathology 92(6): 610-616.

HONG, C.X. \& MOORMAN, G.W. 2005. Plant pathogens in irrigation water: challenges and opportunities. Critical Rewiews in Plant Sciences, 24(3): 189-208.

HONG, C.X.; GALLEGLY, M.E.; RICHARDSON, P.A; KONG, P.; MOORMAN, G.W.; LEA-COX, J.D. \& ROSS, D.S. 2010. Phytophthora hydropathica, a new pathogen identified from irrigation water, Rhododendron catawbiense and Kalmia latifolia.Plant Pathology, 59(5): 913-921.

HONG, C.X.; GALLEGLY, M.E.; RICHARDSON, P.A.; KONG, P. \& MOORMAN, G.W. 2008. Phytophthora irrigata, a new species isolated from irrigation reservoirs and rivers in Eastern United States of America. FEMS Microbiology Letters, 285(2): 203-11.

HÜBERLI, D.; HARDY, G.E.ST.J.; WHITE, D.; WILLIAMS, N. \& BURGESS, T.I. 2013. Fishing for Phytophthora from Western Australia's waterways: a distribution and diversity survey. Australasian Plant Pathology, 42(3): 251-60. 
HUDSON, H.J. 1986. Fungal Biology. London: Edward Arnold, Ltd. 298 p.

IBGE. 2014. Levantamento sistemático da produção agrícola. http://ftp.ibge.gov.br/Producao_Agricola/Levantamento_Sistematico_da_Producao_Agricol a_[mensal]/Fasciculo/lspa_201401.pdf. Consultado em: julho/2014.

INDEX FUNGORUM. 2014. http://www.indexfungorum.org/names/names.asp. Consultado em: agosto/2014.

JENKINS, S.F. \& AVERRE, C.W. 1983. Root diseases of vegetables in hydroponic culture systems in North Carolina greenhouses. Plant Disease, 67(9): 968-970.

JOFFILY, I.M. 1947. Alguns ficomicetos aquáticos e terrícolas do Brasil. Boletim da Sociedade Brasileira de Agronomia, 10(2): 95-113.

KIRK, P.M.; CANNON, P.F.; MINTER, D.W. \& STALPERS, J.A. 2008. Dictionary of Fungi. 10th ed. Wallingford, UK: CAB International Publishing. 396 p.

KIZIEWICZ, B.; MAZALSKA, B.; GODLEWSKA, A.; MUSZYŃSKA. E.; KUŚTOWSKA, E. \& ŚWIDERSKA, M. 2006. Occurrence of aquatic fungi in relation to $\mathrm{pH}$ of the sub-surface waters. Ecological processes in extreme conditions. In Revelling in Reference: VII Toruńskie Seminarium Ekologiczne. Stresz. Konf. Nauk. PTEkol. Toruń (in Polish).

KROON, L.P.N.M.; BAKKER, F.T.; VAN DEN BOSCH, G.B.M.; BONANTS, P.J.M. \& FLIER, W.G. 2004. Phylogenetic analysis of Phytophthora species based on mitochondrial and nuclear DNA sequences. Fungal Genetetics and Biology, 41(8): 766-782.

KROON, L.P.N.M.; BROUWER, H.; DE COCK, A.W.A.M. \& GOVERS, F. 2012. The genus Phytophthora anno 2012. Phytopathology, 102(4): 348-364.

LAMOUR, K. (Ed.). 2013. Phytophthora: a global perspective. Vol. 2. CABI.

LAUDERDALE, C.C. \& JONES, R.K. 1997. Monitoring irrigation ponds for Phytophthora sp. in: Proceedings of SNA Research Conference, vol. 42, pp. 225-226.

LEE, S.B. \& TAYLOR, J.W. 1992. Phylogeny of five fungus-like Phytophthora species inferred from the internal transcribed spacers of ribosomal DNA. Molecular Biological Evolution 9(4):636-653.

LÉVESQUE, C.A. \& DE COCK, A.W.A.M. 2004. Molecular phylogeny and taxonomy of the genus Pythium. Mycological Research, 108(12): 1363-1383.

LOPES, C.A.; REIS, A. \& BOITEUX, L.S. 2005. Doenças fúngicas. In: LOPES, C.A. \& ÁVILA, A.C. Doenças do tomateiro. $1^{\mathrm{a}}$ Ed. Brasília: Embrapa Hortaliças. p.17-52.

MACDONALD, J.D.; ALI-SHTAYEH, M.S.; KABASHIMA, J. \& STITES, J. 1994. Occurrence of Phytophthora species in recirculed nursery irrigation effluents. Plant Disease. 78(6): 607-611. 
MARTIN, F.N. 2000. Phylogenetic relationships among some Pythium species inferred from sequence analysis of the mitochondrially encoded cytochrome oxidase II gene. Mycologia, 92(4): 711-727.

MARTIN, F.N. \& TOOLEY, P.W. 2003. Phylogenetic relationships among Phytophthora species inferred from sequence analysis of mitochondrially encoded cytochrome oxidase I and II genes. Mycologia 95(2): 269-284.

MARTIN, F.N.; ABAD, Z.G.; BALCI, Y. \& IVORS, K. 2012. Identification and detection of Phytophthora: reviewing our progress, identifying our needs. Plant Disease, 96(8): 10801103.

MATSUMOTO, C.; KAGEYAMA, K.; SUGA, H. \& HYAKUMACHI, M. 1999. Phylogenetic relationships of Pythium species based on ITS and 5.8S sequences of the ribosomal DNA. Mycoscience, 40(4): 321-331.

MENDES, M.A.S.; SILVA, V.L.; DIANESE, J.C.; FERREIRA, M.A.S.V.; SANTOS, C.E.N.; GOMES NETO, E.; URBEN, A.F. \& CASTRO, C. 1998. Fungos em Plantas no Brasil. Brasília: Embrapa Cenargen, 569p.

MILANEZ, A.I. 1968. Aquatic fungi of the "cerrado" region of São Paulo State. I. First results. Rickia, 3: 97-109.

MILANEZ, A.I. 1970. Contributions to the knowledge of aquatic Phycomycetes of São Paulo State, I: Oomycetes form the west region. Rickia, 5: 23-43.

MIRANDA, M.L. \& PIRES-ZOTTARELLI, C.L.A. 2008. O gênero Pythium no Parque Estadual da Serra da Cantareira, estado de São Paulo, Brasil. Hoehnea, 35: 281-288.

MOREIRA, C.M.. 2010. Fungos em ambientes aquáticos continentais. Tese de Doutorado. Instituto de Botânica de São Paulo. São Paulo, Brasil.

MULLIS, K.B. \& FALOONA, F.A. 1987. Specific synthesis of DNA in vitro via a polymerase catalysed chain reaction. Methods in Enzymology, 155: 335-350.

NASCIMENTO, C.A.; GOMES, E.P.C. \& PIRES-ZOTTARELLI, C.L.A. 2011. Occurrence and distribution of zoosporic organisms in water bodies from Brazilian Cerrado. Mycologia, 103(2): 261-272.

NASCIMENTO, C.A.; SOUZA, J.I.; GOMES, E.P.C. \& PIRES- ZOTTARELLI, C.L.A. 2012. Zoosporic true fungi and heterotrophic straminipiles assemblages from soil of Brazilian Cerrado areas. Fungal Ecology, 5(2): 114-123;

NEHER, D. \& DUNIWAY, J.M. 1992. Dispersal of Phytophthora parasitica in tomato fields by furrow irrigation. Plant disease, 76(6): 582-586.

OUDEMANS, P. V. 1999. Phytophthora species associated with cranberry root rot and surface irrigation water in New Jersey. Plant Disease, 83(3):251-258

PAULA JÚNIOR, T.J. \& VENZON, M. 2007. 101 culturas: Manual de Tecnologias Agrícolas. Belo Horizonte: EPAMIG. 800p. 
PITTIS, J.E. \& COLHOUN, J. 1984. Isolation and identification of Pythiaceous fungi from irrigation water and their pathogenicity to Antirrhinum, tomato and Chamaecyparis lawsoniana. Journal of Phytopathology, 110(4):301-318.

PRASAD, D.; RAJANAIKA, J.H. \& KRISHNA, V. 2009. Diversity of aquatic fungi in relation to environmental conditions in Tunga river (South India). Researcher, 1(6): 54 - 62.

REESER, P.W.; SUTTON, W.; HANSEN, E.M.; REMIGI, P. \& ADAMS G.C. 2011. Phytophthora species in forest streams in Oregon and Alaska. Mycologia, 103(1): 22-35.

REIS, A. 2010. Requeima: doença destrutiva e comum ao tomateiro e à batateira. Brasília, DF: Embrapa Hortaliças. 7p. (Embrapa Comunicado Técnico, 78)

REIS, A.; CAFÉ FILHO, A. C. \& HENZ, G. P. 2007. Phytophthora capsici: patógeno agressivo e comum às solanáceas e cucurbitáceas. Brasília, DF: Embrapa Hortaliça. 8 p. (Embrapa Hortaliças. Circular Técnica, 55).

RIVERO, V.I.; GIAYETTO, A.; ROSSINI, M.; VERA, M. 2011. Detection of Phytophthora cactorum in the irrigation water in commercial orchards of 'Bartlett' pear in Villa Regina, Río Negro, Argentina. In: XI International Pear Symposium 909 (pp. 521526).

ROBIDEAU, G.P.; DE COCK, A.W.A.M, A.; COFFEY, M.D.; VOGLMAYR, H.; BROUWER, H.; BALA, K.; CHITTY, D.W.; DÉSAULNIERS, N.; EGGERTSON, Q.A.; GACHON, C.M.M.; HU, C.; KÜPPER, F.C.; RINTOUL, T.L.; SARHAN, E.; VERSTAPPEN, E.C.P.; ZHANG, Y.; BONANTS, P.J.M.; RISTAINO, J.B. \& LÉVESQUE, C.A. 2011. DNA barcoding of oomycetes with cytochrome c oxidase subunit I and internal transcribed spacer. Molecular ecology resources, 11(6): 1002-1011.

ROONEY, H.M. \& MCKNIGHT, K.H. 1972. Aquatic Phycomycetes of Lily Lake, Utah. Western North American Naturalist, 32(4), 181-189

SANCHEZ, J. \& GALLEGO, E. 2000. Pythium spp. present in irrigation water in the Poniente region of Almería (south-eastern Spain). Mycopathologia, 150(1): 29-38.

SANCHEZ, J.; SANCHEZ-CARA, J. \& GALLEGO, E. 2000. Suitability of ten plant baits for the rapid detection of pathogenic Pythium species in hydroponic crops. European Journal of Plant Pathology, 106(3): 209-214.

SCHROEDER, K.L.; MARTIN, F.N.; DE COCK, A.W.; LÉVESQUE, C.A; SPIES, C.F.; OKUBARA, P.A. \& PAULITZ, T.C. 2013. Molecular detection and quantification of Pythium species: evolving taxonomy, new tools, and challenges. Plant Disease, 97(1): 4-20.

SHOKES, F.M. \& MCCARTER, S.M. 1979. Occurrence, dissemination, and survival of plant pathogens in surface irrigation ponds in southern Georgia. Phytopathology, 69(5):510-516.

SHRESTHA, S.K.; ZHOU, Y. \& LAMOUR, K.H. 2013. Oomycetes baited from streams in Tennessee 2010-2012. Mycologia, 105(6): 1516-23.

SPARROW, F.K. 1960. Aquatic Phycomycetes. (2nd Ed.). University of Michigan. Press Ann Arbor. pp. 11-87. 
SUTTON, W.; HANSEN, E.M.; REESER, P.W.; KANASKIE, A. 2009. Stream monitoring for detection of Phytophthora ramorum in Oregon tanoak forests. Plant Disease, 93(11):1182-1186.

THEMANN, K. \& WERRES, S. 1997. In vitro comparison of diferente diagnostic methods for the detection of Phytophthora species in water. In: Proceedings of the 9th International Congress on Soilless Culture, Wageningen 1996, 535-550.

THEMANN, K.; WERRES, S.; DIENER, H.A. \& LÜTTMANN, R. 2002. Comparison of different methods to detect Phytophthora spp. in recycling water from nurseries. Journal of Plant Pathology, 84(1): 41-50.

THINGGAARD, K. \& MIDDELBOE, A.L. 1989. Phytophthora and Pythium in pot plant cultures grown on ebb and flow bench with recirculating nutrient solution. Journal of Phytopathology, 125(4): 343-352

THOMSON, S.V. \& ALLEN, R.M. 1974. Occurrence of Phytophthora species and other potential plant pathogens in recycled irrigation water. Plant Disease Reporter, 58(10): 945949.

THON, M.R. \& ROYSE, D.J. 1999. Partial beta-tubulin gene sequences for evolutionary studies in the basidiomycotina. Mycologia, 91(3): 468-474.

TRIGIANO, R.N.; WINDHAM, M.T. \& WINDHAM, A.S. 2004. Plant Pathology. Concepts and Laboratory Exercises. Boca Raton, CRC.

UZUHASHI, S.; TOJO, M. \& KAKISHIMA, M. 2010. Phylogeny of the genus Pythium and description of new genera. Mycoscience, 51(5): 337-365.

VILLA, N.O.; KAGEYAMA, K.; ASANO, T.. \& SUGA, H. 2006. Phylogenetic relationships of Pythium and Phytophthora species based on ITS rDNA, cytochrome oxidase II and $\beta$ tubulin gene sequences. Mycologia, 93:410-422.

VON BROEMBSEN, S.L. \& DEACON, J.W. 1997. Calcium interference with zoospore biology and infectivity of Phytophthora parasitica in nutrient irrigation solutions.Phytopathology, 87(5): 522-528.

VON BROEMBSEN, S. L. \& WILSON, S. K. 1998. Occurrence of Phytophthora spp. in nursery runoff and recycled irrigation water. Phytopathology, 88(suppl.): S92

VON BROEMBSEN, S.L. 1984. Distribution of Phytophthora cinnamomi in rivers of the southwestern Cape Province. Phytophylactica 16, 227-9.

VORONIN, L.V. 2008. Zoosporic Fungi in Freshwater Ecosystems. Inland Water Biology, 1(4): 341-346.

WATERHOUSE, G.M. 1968. The genus Pythium Pringsheim. Mycological Paper, 110:1-71.

WATERHOUSE, G.M. 1970. The genus Phytophthora. Diagnosis and descriptions. Revised edition. Mycol. Pap. 122:1-59. 
WHITE, T.J.; BURNS, S.L. \& TAYLOR, J.W. 1990. Amplification and direct sequencing of fungal ribosomal RNA genes for phylogenetics. In: INNIS, M.A., GELFAND, D.H., SNINSK, J.J. WHITE, T.J. (Eds.) PCR protocols: a guide to methods and applications. Academic Press Inc, New York, p. 315-322.

WILSON, S.K.; VON BROEMBSEN, S.L.; SMOLEN, M.D. \& ANDREWS, M.W. 1998. Pathogen management in capture and recycle irrigation systems for nurseries. Pages 1-6 (paper no. 98-7004) in: ASAE Meeting Presentation. ASAE, Orlando, FL.

WINTON, L.M. \& HANSEN, E.M. 2001. Molecular diagnosis of Phytophthora lateralis in trees, water, and foliage baits using multiplex ploymerase chain reaction. Forest Pathology, 31(5): 275-283.

ZAPPIA, R.E; HÜBERLI, D, HARDY, G.E.ST.J. \& BAYLISS, K.L. 2014. Fungi and oomycetes in open irrigation systems: knowledge gaps and biosecurity implications. Plant Pathology. 12p. 


\section{CAPÍTULO 1}

Avaliação de folhas largas e estreitas como iscas para a detecção de oomicetos em córregos, represas e reservatórios de água. 


\section{RESUMO}

Ambientes aquáticos abrigam uma diversidade muito grande de microrganismos. Entre esses, espécies dos gêneros Pythium e Phytophthora são encontrados frequentemente em fontes de água e englobam diversas espécies de fitopatógenos que, na maioria das vezes, possuem uma ampla gama de hospedeiros. O monitoramento desses fitopatógenos na água de irrigação pode auxiliar a elaboração de estratégias de manejo antes da introdução e disseminação dessas espécies em áreas cultivadas. No entanto, a ausência de métodos simples e eficientes para a detecção de propágulos de espécies de oomicetos na água da irrigação dificulta o monitoramento desses fitopatógenos e retarda adoção de medidas de controle de doenças de plantas. Dessa forma, o objetivo deste capítulo foi comparar a eficiência de folhas de diferentes espécies vegetais como iscas para a detecção de Phytophthora spp. e Pythium spp. em fontes de água e avaliar a influência de diferentes fatores abióticos sobre a ocorrência dessas espécies. Em todos os locais de coleta e meses avaliados, as folhas de tomateiro apresentaram-se eficientes como iscas para a detecção de Pythium e Phytophthora na água, não sendo afetadas pela variação dos fatores abióticos e pelas diferentes características de cada local. Para Pythium, folhas de capim elefante também possiblitaram uma alta frequência de isolamento, sendo esse mesmo resultado obtido com o uso de folhas de manga como isca para Phytophthora. Durante o estudo, a sazonalidade das espécies encontradas em cada local de coleta foi diferente. As maiores frequências de isolamento de Phytophthora foram obtidas no reservatório do sítio Cachoeira e no córrego Capoeira Grande. Em todas as coletas realizadas em doze meses, somente em setembro, essa frequência foi maior na nascente do Sítio Cachoeira. As maiores frequência de detecção de Pythium ocorreram no córrego do Roncador, no meio BARPN, e no córrego Capoeira Grande, no meio BARPNH.

Palavras-chave: monitoramento, sazonalidade, fatores abióticos, diversidade. 


\section{ABSTRACT}

Aquatic habitats are home to a great diversity of microorganisms. Among these organisms, species of the genera Pythium and Phytophthora are frequently found in water sources and include various species of phytopathogens that in most cases have a wide host range. Monitoring of these plant pathogens in irrigation water can aid the development of management strategies prior to the introduction and spread of these species into cultivated areas. However, the absence of simple and efficient methods for the detection of oomycetes species in irrigation water hinders monitoring of these plant pathogens and slows adoption of measures for the control of plant diseases. Thus, the aim of this chapter was to compare the efficiency of leaves of different plant species as baits for the detection of Phytophthora spp. and Pythium spp. in water sources and assess the influence of different abiotic factors on the occurrence of these species. In all sampling sites and months evaluated, the tomato leaves were shown to be effective as bait for the detection of Pythium and Phytophthora in water and were not affected by variation of abiotic factors and the different characteristics of each site. For Pythium, Napier grass leaves also allowed a high frequency of isolations, with the same result obtained with the use of mango leaves as bait for Phytophthora. During the study, the seasonality of the species found at each collection site was different. The highest isolation frequency for Phytophthora was obtained in the Sítio Cachoeira reservoir and Capoeira Grande stream in eleven out of twelve months of collection. In all samplings carried out in twelve months, only in september, this rate was higher in the Sítio Cachoeira headspring. The highest frequency of detection of Pythium occur in the Roncador stream, in the medium PARPN, and in the Capoeira Grande stream, in the medium PARPNH.

Keywords: monitoring, seasonality, abiotic factors, diversity. 


\section{INTRODUÇÃO}

O tomateiro (Solanum lycopersicum L.) é uma das hortaliças mais importantes para atividade agrícola mundial (Clemente \& Boiteux, 2012). A produção mundial de tomate concentra-se principalmente na China, Índia e Estados Unidos (FAOSTAT, 2012). No Brasil, o tomateiro é cultivado em todas as regiões, que juntas produzem quase quatro milhões de toneladas e colocam o país entre os dez maiores produtores mundiais (IBGE, 2014).

O sucesso no cultivo de tomate depende do emprego de diversas tecnologias como o uso de agrotóxicos para o controle de pragas e doenças, o uso de fertilizantes que permitem corrigir características impróprias ao cultivo e o uso da irrigação em períodos secos do ano. O emprego desta última ferramenta tem papel relevante no manejo de doenças de plantas e é capaz de influenciar a epidemiologia e o desenvolvimento de determinadas doenças, podendo favorecer a disseminação do patógeno dentro da lavoura ou permitir a introdução deste em áreas livres de doença (Rotem \& Palti. 1969).

Essa última situação tem sido mais comumente constatada em locais que reciclam ou reutilizam a água de irrigação, como ocorre em países da América do Norte e da Europa (Bush et al., 2003). A reciclagem de água de irrigação é defendida devido à crescente preocupação ambiental com a contaminação de cursos de água ou do lençol freático com fertilizantes e agrotóxicos carreados com a água da irrigação e à necessidade de economia deste recurso, garantindo o abastecimento futuro (Lauderdale \& Jones, 1997; Wilson et al., 1998; Bush, 2002). Porém, apesar dessas vantagens, a ocorrência de inúmeros patógenos de plantas, como bactérias, fungos, nematoides e oomicetos, que tem estruturas de sobrevivência reintroduzidas e o inóculo renovado a cada safra com esta prática tem sido verificada em diversas regiões (Hong \& Moorman, 2005). 
Entre os microrganismos que frequentemente são detectados em fontes de água, as espécies pertencentes ao Filo Oomycota tem se destacado. Dentro deste Filo, encontramos importantes fitopatógenos que incluem várias espécies dos gêneros Pythium e Phytophthora. Esses oomicetos possuem a capacidade de disseminação e sobrevivência na água devido à produção de zoósporos móveis que frequentemente são encontrados em fontes de água de irrigação (Hong \& Moorman, 2005; Rivero et al., 2010; Zappia et al., 2014).

As perdas de produção observadas em campo muitas vezes podem estar associadas à presença destes patógenos na água. O conhecimento da ocorrência, distribuição e dinâmica populacional de oomicetos em ambientes aquáticos é essencial para prevenção da introdução e disseminação em áreas cultivadas e para a formulação de estratégias de manejo de doenças causadas por Pythium e Phytophthora (Zappia et al., 2014).

Por exemplo, a confirmação da presença de Phytophthora ramorum em córregos próximos a florestas de carvalho infectadas com essa espécie na América do Norte retomou o questionamento a respeito da importância epidemiológica da sobrevivência e dispersão de fitopatógenos em fontes de água próximas a hospedeiros suscetíveis. Isto tornou o monitoramento dessa espécie em córregos uma prática imprescindível para a realização de programas de quarentena vegetal e erradicação do patógeno nos Estados Unidos (Sutton et al., 2009).

De maneira semelhante, a presença de espécies reconhecidamente fitopatogênicas na água, como Phytophthora nemorosa e Phytophthora siskiyouensis, agentes causais de cancro da haste em plantas lenhosas, bem como Pythium aphanidermatum, que causa tombamento de mudas e podridão radicular em uma ampla gama de hospedeiros, também tem incentivado trabalhos de detecção precoce de fitopatógenos em fontes de água (Shokes \& McCarter, 1979; Reeser et al., 2007; 2011). 
Nos últimos anos, o aumento da descrição de novas espécies aquáticas de Pythium e Phytophthora tem despertado o interesse sobre o risco da utilização de água contaminada na irrigação de plantas cultivadas. Na Alemanha, Nechwatal \& Mendgen (2006) encontraram uma nova espécie de Pythium descrita como P. litorale no lago Constance. Essa espécie também foi encontrada em rios e córregos dos Estados Unidos e sua patogenicidade foi testada em abobrinha (Cucurbita pepo L.), comprovando sua capacidade de causar tombamento de mudas e podridão de frutos e raízes em testes realizados em casas de vegetação (Parkunan \& Ji, 2013). Da mesma forma, Phytophthora irrigata e Phytophthora hydropathica, espécies relatadas inicialmente na água, apresentaram também a capacidade de infectar várias plantas, incluindo algumas espécies ornamentais, pimenta e tomateiro (Hong et al., 2008).

O monitoramento de espécies de Pythium e Phytophthora depende muito da acurácia e sensibilidade do método utilizado para detecção de determinada espécie. A amostragem de córregos, rios e reservatórios é uma das principais formas de detectar esses oomicetos aquáticos. Utilizando esta técnica, Bush et al. (2003) detectaram seis espécies de Phytophthora e vários isolados de Pythium spp. em um sistema de reciclagem da irrigação em um viveiro a partir da filtração de amostras de água e uso de meio seletivo. Da mesma forma, Parkunan \& Ji (2013) realizaram amostragem da água armazenada em tanques e conseguiram confirmar a presença de Pythium litorale em todos os meses em que as coletas foram realizadas.

A eficiência do uso de folhas como iscas para detecção de oomicetos em córregos, rios e represas, ou ainda em amostras de água recém coletadas também tem sido comprovada em diversos estudos. Sánchez et al. (2000) utilizaram dez diferentes tipos de iscas, entre elas, folhas de laranja (Citrus aurantium L.), tomateiro (Solanum lycopersicum Mill.) e grama Bermuda (Cynodon dactylon L.) que foram colocadas em água contaminada 
com espécies de Pythium e observaram a velocidade de colonização. Em apenas um dia as folhas já estavam infectadas pelas espécies de $P$. irregulare e $P$. aphanidermatum. Comparando o uso de folhas como iscas, o plaqueamento direto de filtros e o método de ELISA, Themann et al. (2002) observaram uma maior taxa de detecção de espécies de Phytopthora em amostras de água com uso de folhas de rododendro como iscas.

Em 2009, Ghimire et al. (2009) testaram a eficiência de folhas inteiras e discos foliares de Camélia (Camellia japonica), azevinho (Ilex crenata) e rododendro (Rhododendron catawbiense) como iscas para espécies de Phytophthora. Após as iscas serem submersas em uma bacia que armazenava a água proveniente da irrigação de viveiros, cinco espécies e um táxon não identificado de Phytophthora foram recuperados, sendo que apenas as folhas de rododendro foram infectadas com todas as espécies encontradas no estudo.

Além da influência do método utilizado sobre a taxa de detecção das espécies, a ocorrência de oomicetos na água em diferentes épocas do ano pode estar relacionada também a variações observadas nos fatores abióticos, como temperatura, $\mathrm{pH}$, concentração de sais, turbidez, entre outros. Paliwal \& Sati (2009) relacionaram diferenças no número de espécies de oomicetos recuperadas da água em diferentes épocas do ano com as alterações observadas na temperatura, pH e matéria orgânica. Da mesma forma, Prasad et al., (2009) avaliaram a influência de diferentes fatores físico-químicos sobre a ocorrência e distribuição de fungos e oomicetos aquáticos, confirmando que a presença das espécies em diferentes estações do ano é afetada pelas diferenças de temperatura, $\mathrm{pH}$ e matéria orgânica. No cerrado brasileiro, Nascimento (2010) relatou mudanças na estrutura da comunidade de organismos zoospóricos em corpos d'água localizados no Estado de São Paulo, possivelmente associadas às variações nos fatores abióticos avaliados em cada ponto amostrado. 
No Brasil, o monitoramento de espécies de Pythium e Phytophthora em fontes de água ainda é muito incipiente. O conhecimento sobre a diversidade, a sazonalidade e a distribuição de espécies fitopatogênicas em ecossistemas aquáticos e sua implicação no manejo de doenças de plantas ainda é muito escasso. Os trabalhos voltados ao isolamento e identificação de espécies zoospóricas da água concentram-se principalmente em áreas preservadas no Sudeste do país (Milanez, 1970; Miranda \& Pires-Zottarelli, 2008; Nascimento et al., 2011; Nascimento \& Pires Zottarelli, 2012). Entretanto, um trabalho preliminar realizado por Freitas et al. (2001) indica a ocorrência de fitopatógenos na água de irrigação no Distrito Federal, associando ainda a presença desses patógenos à incidência de tombamento de mudas em diversas espécies vegetais.

A carência de pesquisas que objetivam o desenvolvimento de métodos de detecção para avaliar a presença de patógenos em diferentes ecossistemas pode dificultar a prevenção de futuras infecções ou retardar a aplicação de métodos de controle eficientes. A detecção precoce e a correta identificação das espécies de fitopatógenos em fontes de água pode subsidiar a aplicação de medidas de controle efetivas.

Os objetivos deste trabalho são: comparar a eficiência de folhas de diferentes espécies vegetais como iscas para a detecção de Phytophthora spp. e Pythium spp. em fontes de água e avaliar a influência de meios de cultura e diferentes fatores abióticos sobre a diversidade e a taxa de isolamento dessas espécies. 


\section{MATERIAL E MÉTODOS}

\subsection{Locais de coleta}

Para o desenvolvimento deste trabalho foram selecionados quatro locais de amostragem (Figura 2):

O primeiro local de coleta localiza-se no Centro Nacional de Pesquisa de Hortaliças (Embrapa Hortaliças), localizada na zona rural da Ponte Alta, Cidade Satélite do Gama-DF.

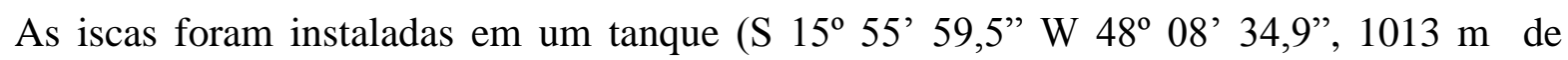
altitude) com dimensões de 50x50m e altura de $3 \mathrm{~m}$, totalizando uma capacidade de 7.500 $\mathrm{m}^{3}$, que armazena a água proveniente dos Córregos Capoeira Grande e Córrego Ponte Alta e abastece os campos experimentais da Embrapa Hortaliças. Além deste reservatório, as iscas foram colocadas no Córrego Capoeira Grande (S 15 56’38,4” W 48 08' 25,7’”, 1072 m de altitude), que nasce dentro da Embrapa Hortaliças e é responsável por fornecer água de boa qualidade para a irrigação dos experimentos conduzidos em campo, irrigando uma área de cerca de 20 ha (Silva et al., 2004).

O segundo local de amostragem escolhido localiza-se no sítio Cachoeira, situado no Núcleo Rural Boa Esperança, na cidade satélite de Ceilândia-DF. As iscas foram instaladas em uma nascente (S 15 49' 25” W 48 14'37,6”, 1080 m de altitude) e em um reservatório (S 15 49' 27,5” W $48^{\circ} 14^{\prime} 45,5^{\prime}, 1116 \mathrm{~m}$ de altitude) que capta água desta mesma nascente e de um poço artesiano.

O terceiro ponto de coleta localiza-se na Reserva Ecológica do IBGE (RECOR), situado a aproximadamente $26 \mathrm{~km}$ ao sul de Brasília. A RECOR possui uma área de 1300 hectares caracterizada como uma área de proteção ambiental, destinada à conservação da diversidade do cerrado. O local escolhido para instalação das iscas foi o córrego do 
Roncador (S 16 $06^{\circ}$ 49,3” W $48^{\circ} 02^{\prime} 23,5^{\prime \prime}, 1060 \mathrm{~m}$ de altitude), o mais importante tributário da Bacia do Córrego Taquara, possuindo cerca de $3.625 \mathrm{~m}$ de comprimento, profundidade média em torno de $78 \mathrm{~cm}$ e largura média de $3,50 \mathrm{~m}$. Suas nascentes localizam-se nas proximidades do limite da RECOR com a Estação Ecológica do Jardim Botânico de Brasília, cerca de 700 m da BR 251 (Lima, 1995). Esse local foi adicionado a este trabalho para servir como controle por não haver atividade agrícola nas proximidades, em contraste com os outros pontos de amostragem.

O último local de amostragem está localizado na Fazenda Larga Grande, no munícipio de Luziânia-GO. A propriedade possui 20 pivôs centrais, em que são plantadas diversas culturas como milho, sorgo e soja em diferentes épocas do ano. O tomateiro é cultivado em 12 pivôs que juntos possuem uma área de 1.219 ha. As iscas foram colocadas em um córrego ( $\mathrm{S} 16^{\circ} 18^{\prime} 41,6^{\prime \prime} \mathrm{W} 47^{\circ} 32^{\prime}$ 50,2”, $956 \mathrm{~m}$ de altitude) e em uma das represas que fornecem água para a irrigação do tomateiro ( $\mathrm{S} 16^{\circ} 23^{\prime} 36,4^{\prime \prime} \mathrm{W} 47^{\circ} 31$ ' 23,4”, $872 \mathrm{~m}$ de altitude). 


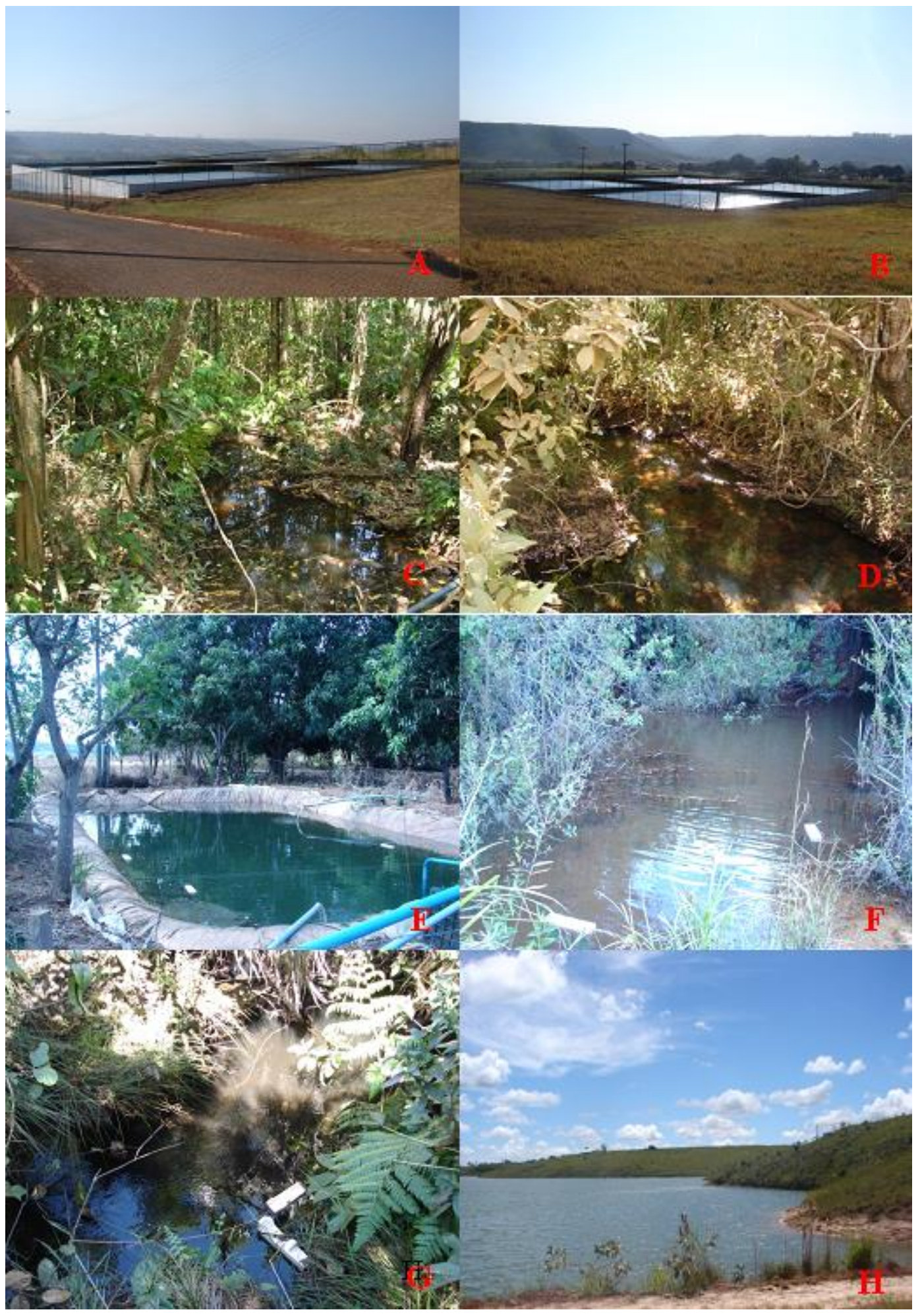

Figura 2. Locais de amostragem utilizados no estudo: tanque (A) (B) e córrego Capoeira Grande (C), Embrapa Hortaliças; córrego do Roncador (D), Reserva Ecológica do IBGE; reservatório (E) e nascente (F) do Sítio Cachoeira, Núcleo Rural Boa Esperança; e Córrego (G) e represa (H), Fazenda Larga Grande, Luziânia-GO. 


\subsection{Preparo das iscas e isolamento em meio de cultura}

As iscas selecionadas foram folhas recém coletadas de seis espécies diferentes, nas quais três possuíam folhas estreitas: pinos (Pinus elliottii L.), capim elefante (Pennisetum purpureum L.) e uma palmeira ornamental (Dypsis lutescens L.); e três possuíam folhas largas: laranja (Citrus sinsensis L.), manga (Mangifera indica L.) e tomate (Solanum lycopersicum cv. Viradouro).

Após a coleta, as folhas foram levadas ao laboratório para desinfestação e lavagem. Para cada ponto de amostragem, foram escolhidas oito folhas de cada espécie para serem depositadas em bolsas de coleta $(20 \times 40 \mathrm{~cm})$ preparadas com tela plástica permeável e divididas em quatro seções. Cada seção continha duas folhas com a parte abaxial voltada para fora. Para o pinheiro, apenas um fascículo contendo várias acículas foi coletado e inserido em uma bolsa sem divisão.

Após o preparo das iscas, as bolsas foram levadas ao local de coleta e fixadas, com auxílio de barbantes, em estacas presentes na margem. No interior de cada bolsa, foi adicionado material pedregoso para evitar que as iscas permanecessem na superfície da água. Após três dias, as iscas foram retiradas dos pontos de amostragem e levadas ao Laboratório de Fitopatologia da Embrapa Hortaliças para serem processadas. As coletas em cada local de amostragem foram realizadas mensalmente durante doze meses, com início no mês de setembro/2013 e término no mês de agosto/2014.

No laboratório, as folhas foram lavadas em água corrente para retirada das impurezas, como matéria orgânica e material inerte, e em seguida foram observadas quanto à presença de lesões características de infecção por zoósporos de oomicetos. Após a secagem do material foram escolhidas cinco porções de cada folha, que apresentassem as lesões. Os discos e seções das folhas tinham aproximadamente $1 \mathrm{~cm}$ de diâmetro e foram 
distribuídos equidistantemente em oito placas de Petri descartáveis, com diâmetro de 90 mm, para cada espécie vegetal (Figura 3). As placas continham meio V8-ágar clarificado preparado como descrito abaixo, sendo que em quatro dessas placas foi adicionado o meio BARPN e nas demais quatro placas adicinou-se o meio BARPNH, compostos por fungicidas e antibióticos especificados a seguir. Como controle, discos foliares de cada espécie vegetal foram retirados de folhas não submersas nas fontes de água e distribuídos em meio de cultura seletivo.

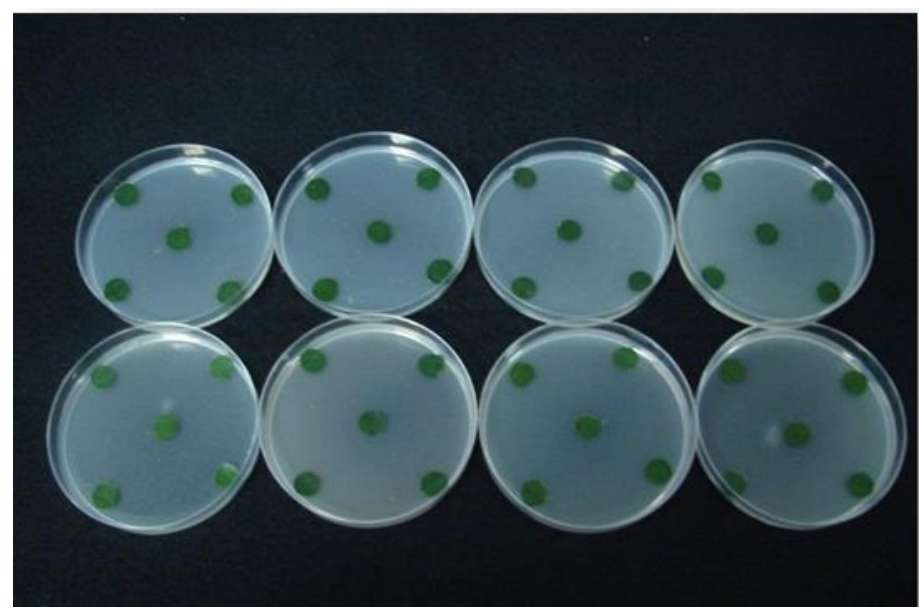

Figura 3. Isolamento das folhas utilizadas como iscas em placas de Petri contendo meio V8ágar seletivo.

Para o isolamento foi utilizado meio V8 Campbell clarificado. Para o preparo deste meio, utilizou-se inicialmente $15 \mathrm{~g}$ de Carbonato de Cálcio $\left(\mathrm{CACO}_{3}\right)$ e $500 \mathrm{ml}$ de V8. Para a completa homogeneização, essa solução foi agitada de 15 a 20 minutos em agitador magnético com auxílio de uma barra magnética e em seguida transferidos para tubos de centrífuga com capacidade de $120 \mathrm{ml}$ e centrifugada por 6 minutos a uma velocidade de 1800 a 2000 rpm (rotações por minuto) na centrífuga (modelo GF-8, marca Fanem). Após a separação das fases, apenas a fase líquida foi utilizada para o preparo final do meio, que continha $100 \mathrm{ml}$ de V8 clarificado, $900 \mathrm{ml}$ de água destilada e 18 g de ágar. 
Para o preparo do meio seletivo adicionou-se antibióticos e fungicidas nas seguintes concentrações: Benomyl (40 ppm) (E. I. duPont De Nemours, Inc. Wilmington, DE), Ampicilina (100 ppm) (Sigma Chemical Co. St. Louis, MO), Rifampicina (10 ppm) (Sigma Chemical Co., St. Louis, MO), Pentacloronitrobenzeno PCNB (30 ppm) (Uniroyal Chemical Co. Naugatuck, CT) e Nistatina (50ppm) (Sigma Chemical Co., St. Louis, MO), que comporam o meio BARPN (Masago et al., 1977). Por último, foi adicionado Hymezaxol (50 ppm) (Sankyo, Tokyo, Japan) que inibe o crescimento de várias espécies de Pythium, técnica que permite a seleção de colônias puras de Phytophthora que apresentam crescimento micelial mais lento que o Pythium em meio de cultura, constituindo assim o meio BARPNH.

A avaliação das placas foi realizada no segundo e terceiro dia após o isolamento. A avaliação consistia na contagem das colônias de Pythium e Phytophthora que cresceram em cada disco foliar. Desta forma, constatou-se o potencial de cada espécie como isca para detecção de oomicetos por meio da proporção entre o número de discos nos quais as colônias se desenvolveram sobre o número total de discos utilizados no isolamento.

Após cada avaliação, os isolados, representativos de cada local e isca e que apresentavam características morfológicas distintas, foram repicados para meio de cultura V8 ágar clarificado. Para realização dos estudos posteriores e para a preservação dos isolados, discos das colônias puras foram destacados da margem e foram transferidos para tubos contendo meio V8 ágar que foram cobertos com óleo mineral após o desenvolvimento micelial e mantidos em temperatura ambiente (Erwin \& Ribeiro, 1996). 


\subsection{Avaliação dos fatores abióticos}

No momento da instalação das iscas, a temperatura da água foi aferida por meio de termômetro com coluna de mercúrio. Da mesma forma, amostras de água da represa, dos córregos e dos reservatórios foram coletadas e levadas ao Laboratório de Fitopatologia da Embrapa Hortaliças para medição do pH e da absorbância. $\mathrm{O}$ pH foi medido através de pHmetro F-71 LAQUA - Horiba e a absorbância através do espectrofotômetro B495 Micronal $(\mathrm{A}=600 \mathrm{~nm})$.

\subsection{Delineamento experimental e análise dos dados}

O delineamento experimental foi inteiramente casualizado em um arranjo fatorial: local (7), mês (12) e isca (6). A análise de variância (ANOVA) considerou apenas os efeitos

principais e as interações duplas. Os dados foram transformados para arcseno $\sqrt{x}$, onde $\mathrm{x}$ é igual à proporção entre o número de discos em que as colônias cresceram e o número total de discos utilizados no isolamento. A transformação foi usada para satisfazer as suposições da ANOVA: homogeneidade de variância e normalidade dos dados de acordo com Gomez \& Gomez (1984). Neste trabalho, as hipóteses a serem avaliadas foram:

1. Não existe diferença significativa entre as iscas, entre os meses e entre os locais de coleta em cada meio de cultura;

2. A taxa de detecção de oomicetos entre os locais de coleta é igual nos meses avaliados;

3. Não existe diferença significativa entre as iscas nos meses e locais de coleta em determinado meio de cultura; 
4. As frequências de isolamento de Phytophthora e Pythium são iguais para cada isca em um mesmo meio de cultura;

5. As frequências de isolamento de Phytophthora e Pythium são iguais no mesmo meio de cultura em cada local de coleta. 


\section{RESULTADOS E DISCUSSÃO}

Os fatores abióticos avaliados são apresentados na Tabela 1. As temperaturas da água mais altas foram observadas no tanque da Embrapa Hortaliças e na represa da Fazenda Larga Grande, com média de $24,75^{\circ} \mathrm{C}$ e $25,2^{\circ} \mathrm{C}$, respectivamente. No tanque a maior temperatura foi registrada no mês de janeiro $\left(30^{\circ} \mathrm{C}\right)$ e abril $\left(29^{\circ} \mathrm{C}\right)$ e a amplitude térmica entre os doze meses foi de $10^{\circ} \mathrm{C}$. Já na represa, as maiores temperaturas foram $29^{\circ} \mathrm{C}$ em dezembro e $27^{\circ} \mathrm{C}$ em fevereiro e março, com amplitude anual de $7^{\circ} \mathrm{C}$.

Em todos os demais locais, a amplitude térmica anual foi aproximadamente $4^{\circ} \mathrm{C}$. As temperaturas mais baixas foram observadas no córrego do Roncador e no córrego Capoeira Grande, com a média em torno de $19^{\circ} \mathrm{C}$. Já nos dois pontos de amostragem do Sítio Cachoeira a temperatura média foi $23^{\circ} \mathrm{C}$.

No tanque, o pH observado variou de básico, em torno de 9 nos meses de outubro e novembro a neutro com $\mathrm{pH}$ 7,3 nos meses de Julho e Agosto. O pH mais ácido foi observado no córrego da Faz. L. Grande (em média 5,8). O pH médio dos demais locais de coleta ficou entre 6 e 7.

A absorbância variou de 0,00 a 0,03 no C. Roncador e no C. C. Grande, e ficou entre 0,00 a 0,02 no reservatório do St. Cachoeira e na represa da Faz. L. Grande. A maior absorbância observada foi 0,04 no tanque durante o mês de outubro. 
Tabela 1. Fatores abióticos analisados em cada amostragem realizada entre setembro/2013 a agosto/2014.

\begin{tabular}{|c|c|c|c|c|c|c|c|c|c|c|c|c|c|c|c|}
\hline Loca & de coleta & Dados climáticos & set/13 & out $/ 13$ & nov/13 & dez/13 & jan/14 & fev/14 & $\operatorname{mar} / 14$ & abr/14 & mai/14 & jun/14 & jul/14 & ago/14 & Média \\
\hline \multirow{6}{*}{$\begin{array}{l}\text { Embrapa } \\
\text { Hortaliças }\end{array}$} & \multirow{3}{*}{ Tanque } & Temperatura $\left({ }^{\circ} \mathbf{C}\right)$ & 23 & 25 & 24 & 25 & 30 & 27 & 26 & 29 & 25 & 24 & 19 & 20 & 24,75 \\
\hline & & pH & 7,85 & 9,09 & 9,48 & 7,73 & 7,47 & 8,71 & 7,95 & 8,3 & 8,57 & 7,54 & 7,3 & 7,3 & 8,11 \\
\hline & & Absorbância & 0,02 & 0,04 & 0,01 & 0,01 & 0,01 & 0,02 & 0,01 & 0,02 & 0,02 & 0,01 & 0,02 & 0,01 & 0,02 \\
\hline & \multirow{3}{*}{$\begin{array}{c}\text { Córrego Capoeira } \\
\text { Grande }\end{array}$} & Temperatura $\left({ }^{\circ} \mathbf{C}\right)$ & 18 & 21 & 20 & 20 & 21 & 21 & 21 & 21 & 20 & 20 & 17 & 18 & 19,83 \\
\hline & & $\mathbf{p H}$ & 6,8 & 7,28 & 6,46 & 7,52 & 6,37 & 6,14 & 6,85 & 6,2 & 6,48 & 5,97 & 6,52 & 5,71 & 6,53 \\
\hline & & Absorbância & 0,00 & 0,03 & 0,01 & 0,02 & 0,01 & 0,01 & 0,00 & 0,00 & 0,00 & 0,00 & 0,00 & 0,00 & 0,01 \\
\hline \multirow{6}{*}{ Sítio Cachoeira } & \multirow{3}{*}{ Reservatório } & Temperatura $\left({ }^{\circ} \mathbf{C}\right)$ & 22,5 & 25 & 24 & 23,5 & 25 & 23 & 24 & 25 & 21 & 22 & 22 & 22 & 23,25 \\
\hline & & pH & 7,4 & 6,69 & 5,5 & 5,84 & 6,6 & 6,83 & 7,34 & 7,39 & 6,86 & 6,68 & 6,9 & 6,38 & 6,70 \\
\hline & & Absorbância & 0,00 & 0,00 & 0,01 & 0,02 & 0,01 & 0,01 & 0,00 & 0,01 & 0,00 & 0,01 & 0,00 & 0,01 & 0,01 \\
\hline & \multirow{3}{*}{ Nascente } & Temperatura $\left({ }^{\circ} \mathbf{C}\right)$ & 21,5 & 25 & 25 & 23 & 25 & 24 & 23 & 25 & 22 & 22 & 21 & 20,5 & 23,08 \\
\hline & & pH & 7,3 & 6,68 & 5,45 & 5,74 & 6,03 & 6,6 & 7,21 & 6,58 & 6,72 & 6,54 & 6,71 & 5,72 & 6,44 \\
\hline & & Absorbância & 0,01 & 0,00 & 0,01 & 0,01 & 0,01 & 0,01 & 0,00 & 0,00 & 0,01 & 0,01 & 0,01 & 0,01 & 0,01 \\
\hline \multirow{3}{*}{ RECOR } & \multirow{3}{*}{ Córrego do Roncador } & Temperatura $\left({ }^{\circ} \mathbf{C}\right)$ & 20 & 19 & 20 & 20 & 20 & 20 & 20 & 19 & 19 & 19 & 17 & 17 & 19,17 \\
\hline & & pH & 7,27 & 5,95 & 5,48 & 6,5 & 5,96 & 6,03 & 5,93 & 6,14 & 5,4 & 5,65 & 6,1 & 6,01 & 6,04 \\
\hline & & Absorbância & 0,00 & 0,00 & 0,00 & 0,00 & 0,00 & 0,00 & 0,00 & 0,01 & 0,00 & 0,00 & 0,00 & 0,03 & 0,00 \\
\hline \multirow{6}{*}{$\begin{array}{l}\text { Fazenda Larga } \\
\text { Grande }\end{array}$} & \multirow{3}{*}{ Represa } & Temperatura $\left({ }^{\circ} \mathbf{C}\right)$ & - & - & 26 & 29 & 26 & 27 & 27 & 25 & 24 & 23 & 23 & 22 & 25,20 \\
\hline & & pH & - & - & 5,95 & 5,6 & 6,28 & 6,54 & 6,46 & 6,09 & 6,24 & 6,45 & 6,4 & 6,2 & 6,22 \\
\hline & & Absorbância & - & - & 0,01 & 0,01 & 0,01 & 0,00 & 0,02 & 0,00 & 0,00 & 0,00 & 0,02 & 0,01 & 0,01 \\
\hline & \multirow{3}{*}{ Córrego } & Temperatura $\left({ }^{\circ} \mathbf{C}\right)$ & - & - & - & 23,5 & 22 & 22 & 22 & 21 & 20 & 19 & 22 & 21 & 21,39 \\
\hline & & pH & - & - & - & 4,75 & 5,08 & 6,4 & 6 & 5,81 & 5,87 & 5,74 & 6,3 & 6,3 & 5,81 \\
\hline & & Absorbância & - & - & - & 0,01 & 0,01 & 0,00 & 0,00 & 0,01 & 0,00 & 0,00 & 0,01 & 0,00 & 0,00 \\
\hline
\end{tabular}


Em todos os locais de amostragem foi possível o isolamento de espécies de Pythium e Phytophthora por meio da utilização de iscas (Tabela 2), no entanto, a frequência de detecção desses oomicetos em cada local foi diferente. Dessa forma, a hipótese de que não existe diferença significativa entre os locais para cada meio de cultura foi rejeitada a $\operatorname{Pr}>\mathrm{F}<0,0001$.

Tabela 2. Frequência de detecção (\%) de Phytophthora spp. e Pythium spp em cada local de coleta.

\begin{tabular}{|c|c|c|c|c|c|}
\hline \multirow{2}{*}{ Locais de coleta } & \multicolumn{2}{|c|}{ BARPN } & \multicolumn{2}{|c|}{ BARPNH } & \multirow{2}{*}{ Média } \\
\hline & Phytophthoraa & Pythium & Phytophthoraa & Pythium & \\
\hline C. C. Grande & $64,08 \mathrm{aB}$ & $41,49 \mathrm{bBC}$ & $64,91 \mathrm{aA}$ & $35,90 \mathrm{bA}$ & 51,6 \\
\hline $\begin{array}{l}\text { St. Cachoeira } \\
\text { (reservatório) }\end{array}$ & $67,93 \mathrm{aA}$ & $38,83 \mathrm{bC}$ & $66,56 \mathrm{aA}$ & $34,08 \mathrm{bA}$ & 51,85 \\
\hline $\begin{array}{l}\text { St.Cachoeira } \\
\text { (nascente) }\end{array}$ & $46,09 \mathrm{aC}$ & $42,76 \mathrm{aB}$ & $44,90 \mathrm{aB}$ & $33,34 \mathrm{bAB}$ & 41,77 \\
\hline C. Roncador & $38,81 \mathrm{bD}$ & $46,89 \mathrm{aA}$ & $43,65 \mathrm{aB}$ & $33,08 \mathrm{bAB}$ & 40,61 \\
\hline $\begin{array}{l}\text { Faz. L. Grande } \\
\quad \text { (represa) }\end{array}$ & $27,37 \mathrm{bE}$ & $38,78 \mathrm{aC}$ & $24,98 \mathrm{bC}$ & $30,41 \mathrm{aBC}$ & 30,39 \\
\hline $\begin{array}{l}\text { Faz. L.Grande } \\
\text { (córrego) }\end{array}$ & $21,21 \mathrm{bF}$ & $38,90 \mathrm{aC}$ & $22,81 \mathrm{bC}$ & $27,89 \mathrm{aC}$ & 27,70 \\
\hline Tanque & $26,31 \mathrm{bE}$ & $30,25 \mathrm{aD}$ & $18,24 \mathrm{bD}$ & $24,15 \mathrm{aD}$ & 24,74 \\
\hline Média & 41,69 & 39,7 & 40,86 & 31,26 & \\
\hline
\end{tabular}

\footnotetext{
Médias seguidas de letra iguais, maiúsculas na coluna e minúscula na linha para o mesmo meio de cultura, não diferem entre si pelo teste de Tukey a 5\%.

Meio de cultura BARPN: meio V8 clarificado com Benomyl, Nistatina, Rifampicina, Ampicilina e Pentacloronitrobenzeno. Meio de cultura BARPNH: meio BARPN + Hymexazol.
}

Nos dois meios de cultura avaliados, as maiores taxas de detecção de Phytophthora foram observadas no reservatório localizado no Sítio Cachoeira (St. Cachoeira) e no córrego Capoeira Grande (C. C. Grande). Nos dois pontos de amostragem da Fazenda Larga Grande (Faz. L. Grande) e no tanque da Embrapa Hortaliças foram verificadas as menores frequências de detecção de Phytophthora spp. $(<28 \%)$.

No meio de cultura sem Hymexazol (BARPN), a maior frequência de recuperação de Pythium spp. foi observada no córrego do Roncador (C. Roncador) (46,89\%), diferindo 
estatisticamente de todos os locais de coleta $(\mathrm{p}<0,0001)$. Já no meio de cultura que continha Hymexazol (BARPNH), a maior taxa de isolamento foi observada no C. C. Grande $(35,9 \%)$ e no reservatório do St. Cachoeira (34,08\%).

Novamente, o tanque, o córrego e a represa da Faz. L. Grande nos dois meios de cultura, incluindo reservatório do St. Cachoeira no meio BARPN, também apresentaram as menores frequências de isolamento de Pythium, ficando abaixo de 38,89\% no meio BARPN e abaixo de $30,41 \%$ no BARPNH.

O resultado encontrado nos pontos de amostragem da Faz. L. Grande para os dois gêneros estudados pode ser consequência do aumento da atividade antrópica e da maior utilização de insumos agrícolas que possivelmente entram em contato com a água. Já no tanque da Embrapa Hortaliças, um fator que pode ter sido determinante para uma menor recuperação de espécies de Pythium e Phytophthora foi o alto teor de poluição observada, além do alto $\mathrm{pH}$ da água. Esse tanque constantemente contém grande quantidade de insetos e outros animais em putrefação, que confere à água um cheiro desagradável, mas não interfere muito na sua absorbância. Ao avaliar a influência dos fatores abióticos sobre a ocorrência de fungos zoospóricos na água, Pires-Zottarelli (1999), Silva (2002) e Rocha (2004), demonstraram que qualquer nível de poluição reduz a diversidade desses oomicetos na água. Além disso, a ausência de vegetação ribeirinha nesses locais de amostragem pode ter influência sobre a abundância de espécies de Pythium e Phytophthora, pois a vegetação observada nas margens das fontes de água do St. Cachoeira, do C. C. Grande e do C. Roncador possivelmente fornece substrato e nutrientes para que esses oomicetos se multipliquem e sobrevivam por mais tempo na água (Cooke, 1961; Sparrow, 1968; Prasad et al., 2009; Krauss et al., 2011). A redução na frequência de isolamento de Phytophthora no C. Roncador pode ser consequência da alta frequência de isolamento de Pythium nesse local, que 
possivelemente compete pelo tecido vegetal da isca com as espécies de Phytophthora (Erwin \& Ribeiro, 1996; Bush et al., 2003).

Quando comparamos a taxa de detecção de Phytophthora e Pythium no mesmo meio de cultura para cada local de coleta (Tabela 2), notamos que no meio BARPN, todos os locais, com exceção da nascente do St. Cachoeira, são estatisticamente diferentes. Apenas no C. C. Grande e no reservatório do St. Cachoeira foi possível a detecção de um maior número de isolados de Phytophthora do que de Pythium. No meio BARPNH, todos os locais de coleta também são significativamente diferentes, mas dessa vez a frequência de detecção de isolados de Phytophthora foi maior no C. Roncador, nos dois pontos de coleta do St. Cachoeira e no C. Capoeira Grande. Somente nos dois pontos de amostragem da Faz. L.Grande e no tanque da Embrapa Hortaliças foram recuperados mais isolados de Pythium do que de Phytophthora. Assim, a hipótese de que as frequências de isolamento de Phytophthora e Pythium são iguais no mesmo meio de cultura em cada local de coleta também foi rejeitada ( $\operatorname{Pr}>\mathrm{F}<0,0001)$.

Entre os meses avaliados, a taxa de detecção de Pythium spp. e Phytophthora spp. também é diferente, fazendo com que a hipótese de que não existe diferença significativa entre os meses em cada meio de cultura seja rejeitada mais uma vez com o mesmo nível de significância.

Para Phytophthora no meio BARPN, a taxa de isolamento aumentou a partir de julho (44.56\%), com ápice em outubro $(56,32 \%)$ e declínio no mês de novembro $(48,62)$. No demais meses, a frequência de isolamento teve uma baixa variação, ficando entre 37,28 \% e 41,87\%. No meio BARPNH, a mesma variação foi observada, com a frequência mais alta em outubro $(52,77 \%)$, no entanto a taxa de isolamento começou a aumentar apenas no mês de setembro $(46,7 \%)$, diminuindo gradualmente até dezembro $(42,04 \%)$. A menor taxa de isolamento de Phytophthora ocorreu no mês de abril para os dois meios avaliados (Tabela 3). 
As maiores frequências de detecção de Pythium no meio BARPN são observadas nos meses de maio, junho e julho, com $44,72 \%, 46,7 \%$ e $44,4 \%$, respectivamente. A partir de agosto ocorre um decréscimo na frequência até o mês de janeiro, em que a frequência fica novamente em $41,86 \%$. No meio BARPNH, a frequência de detecção ficou abaixo de $40 \%$. Da mesma forma, as maiores frequências de isolamento são observadas em maio e junho $(38,22 \%$ e $37,75 \%)$. A menor taxa foi observada em novembro, com $22,74 \%$ e $32,62 \%$, nos meios BARPNH e BARPN, respectivamente.

Em todos os meses avaliados, assim como em todos os locais de coleta, a frequência de detecção Pythium foi maior no meio BARPN do que no meio BARPNH, demonstrando que a presença de Hymexazol no meio de cultura reduz a recuperação de isolados de Pythium da água, como já foi comprovado em outros trabalhos (Figura 4) (Masago et al., 1977; Tsao \& Guy, 1977; Jeffers \& Martin, 1986; Bush et al., 2003).

Tabela 3. Frequência de detecção (\%) de Phytophthora spp. e Pythium spp em cada mês de coleta.

\begin{tabular}{cccccc}
\hline $\begin{array}{c}\text { Meses de } \\
\text { coleta }\end{array}$ & \multicolumn{2}{c}{ BARPN } & \multicolumn{2}{c}{ BARPNH } & Média \\
\hline Set & $48,89 \mathrm{~B}$ & $41,68 \mathrm{~B}$ & $46,7 \mathrm{C}$ & $36,35 \mathrm{AB}$ & 43,41 \\
Out & $56,32 \mathrm{~A}$ & $36,69 \mathrm{CD}$ & $52,77 \mathrm{~A}$ & $30,55 \mathrm{CDE}$ & 44,08 \\
Nov & $48,62 \mathrm{~B}$ & $32,62 \mathrm{~B}$ & $45,13 \mathrm{BC}$ & $22,74 \mathrm{~F}$ & 37,28 \\
Dez & $38,95 \mathrm{D}$ & $34,64 \mathrm{D}$ & $42,04 \mathrm{CDE}$ & $28,31 \mathrm{DE}$ & 35,99 \\
Jan & $37,77 \mathrm{D}$ & $41,86 \mathrm{AB}$ & $38,38 \mathrm{E}$ & $32,62 \mathrm{BCD}$ & 37,66 \\
Fev & $39,05 \mathrm{D}$ & $40,01 \mathrm{BC}$ & $39,03 \mathrm{DE}$ & $34,23 \mathrm{ABC}$ & 38,08 \\
Mar & $41,87 \mathrm{CD}$ & $36,55 \mathrm{BC}$ & $41,82 \mathrm{CDE}$ & $31,30 \mathrm{CDE}$ & 37,89 \\
Abr & $37,28 \mathrm{D}$ & $34,95 \mathrm{~B}$ & $38,01 \mathrm{E}$ & $28,69 \mathrm{DE}$ & 34,73 \\
Mai & $41,68 \mathrm{CD}$ & $44,72 \mathrm{AB}$ & $43,46 \mathrm{BCD}$ & $38,23 \mathrm{~A}$ & 42,02 \\
Jun & $38,73 \mathrm{D}$ & $46,69 \mathrm{~A}$ & $41,58 \mathrm{CDE}$ & $37,76 \mathrm{~A}$ & 41,19 \\
Jul & $44,56 \mathrm{BC}$ & $44,43 \mathrm{AB}$ & $39,62 \mathrm{DE}$ & $30,57 \mathrm{CDE}$ & 39,80 \\
Ago & $45,12 \mathrm{BC}$ & $43,02 \mathrm{AB}$ & $38,13 \mathrm{E}$ & $27,02 \mathrm{EF}$ & 38,32 \\
Média & 43,24 & 39,82 & 42,22 & 31,53 & \\
\hline
\end{tabular}

Médias seguidas de letras iguais, maiúsculas na coluna e minúscula na linha para o mesmo meio de cultura, não diferem entre si pelo teste de Tukey a $5 \%$.

Meio de cultura BARPN: meio V8 clarificado com Benomyl, Nistatina, Rifampicina, Ampicilina e Pentacloronitrobenzeno. Meio de cultura BARPNH: meio BARPN + Hymexazol. 

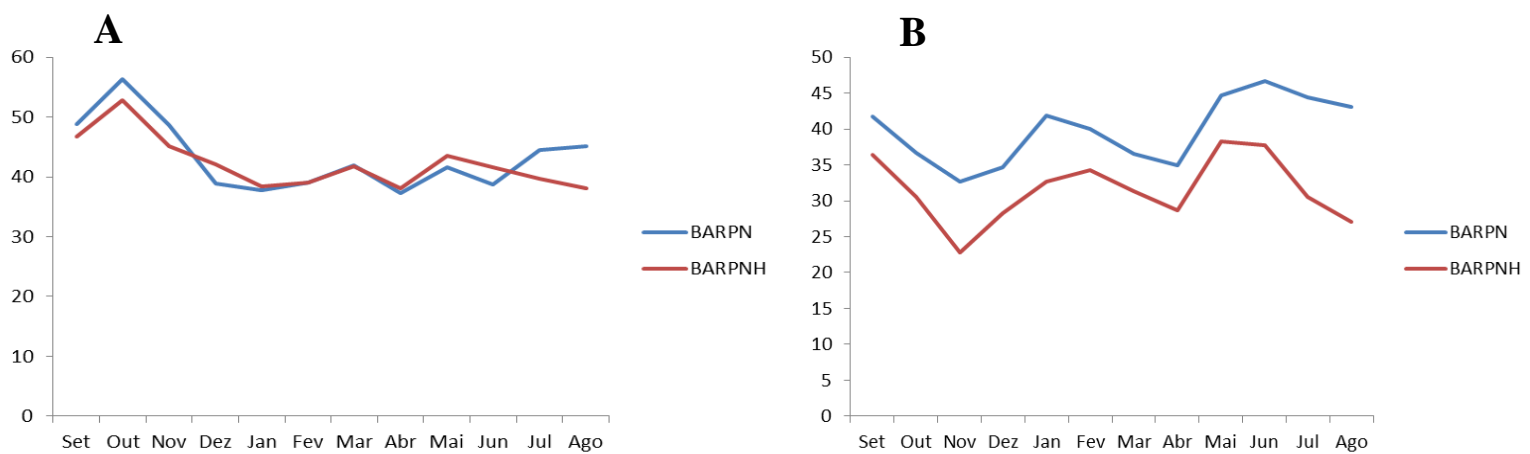

Figura 4. Frequência de detecção (\%) de Phytophthora (A) e Pythium (B) durante os meses de coleta nos meios de cultura BARPN (Gráfico de linha na cor azul) e BARPNH (Gráfico de linha na cor vermelha).

Avaliando a interação entre local e mês (Figuras 5 e 6), a frequência de detecção de oomicetos nos locais de coleta foi diferente em cada mês avaliado. Independente do meio de cultura, as taxas de isolamento de Phytophthora são maiores no reservatório do St. Cachoeira e no C. C. Grande no mês de outubro e entre dezembro e agosto, não havendo diferença estatística entre esses dois locais em nenhum dos meses avaliados. Somente no mês de setembro, a frequência de isolamento foi maior na nascente do St. Cachoeira e menor no C. Capoeira e no tanque. No meio BARPNH, a mesma variação na frequência é observada. Durante o mês de novembro, o C. Roncador apresentou uma taxa de isolamento de 63,58\% que foi muito próxima ao C. Capoeira. Com exceção do mês de junho e agosto no meio BARPN, e do mês de julho nos dois meios de cultura, os dois pontos de amostragem da Faz. L. Grande e o tanque da Embrapa Hortaliças registraram as menores frequências de detecção de isolados de Phytophthora (Figura 5). 

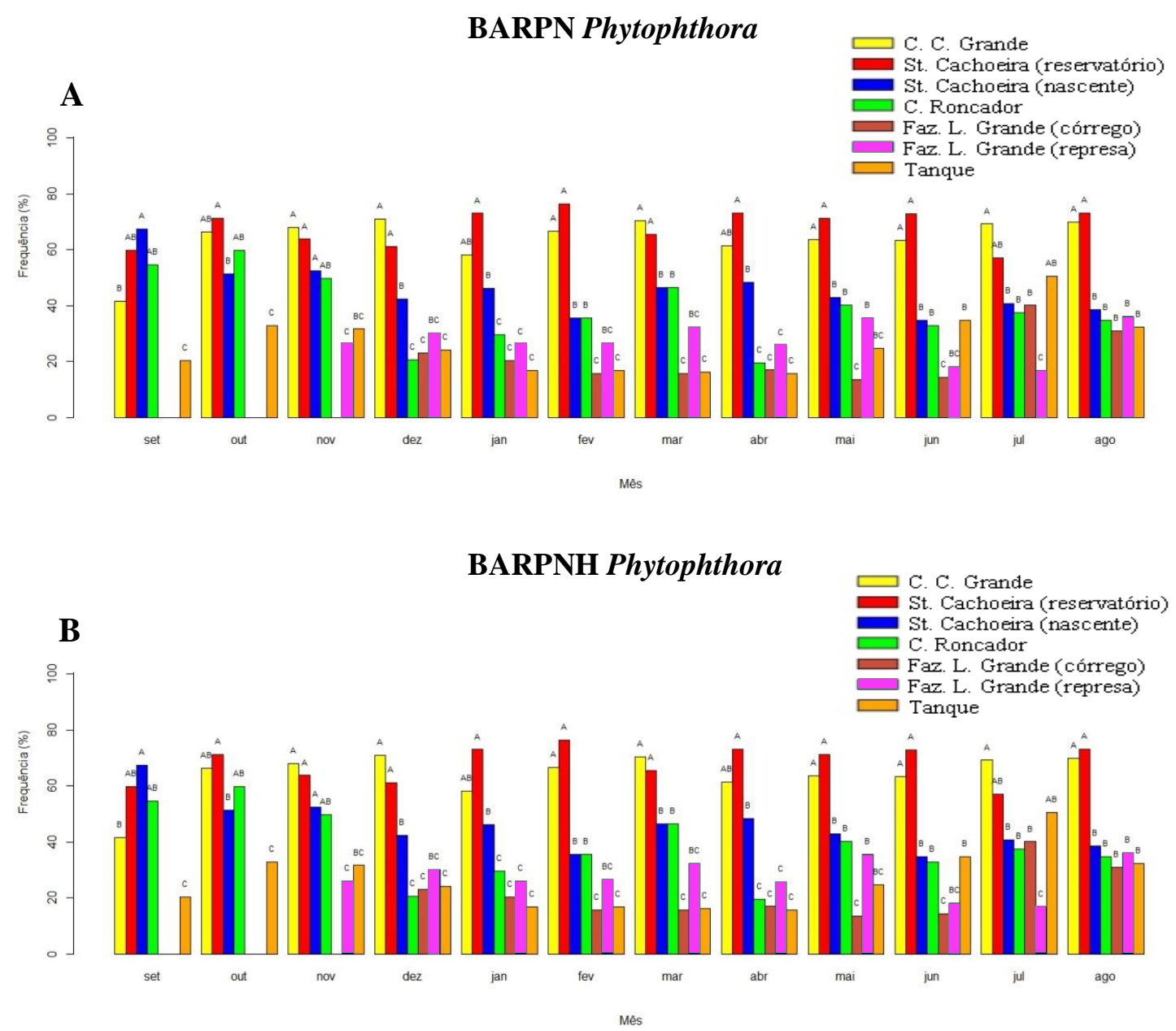

Figura 5. Frequência de isolamento de Phytophthora spp. no meio BARPN (A) e BARPNH (B) em cada local de amostragem durante os meses avaliados (Interação: local x mês). Médias seguidas da mesma letra na coluna em cada mês de coleta não diferem entre si pelo teste de Tukey a 5\%. Meses avaliados: Setembro/2013 a Agosto/2014.

No meio BARPN, as maiores frequências de isolamento de Pythium spp. foram observadas na nascente do St. Cachoeira e no C. Roncador entre os meses de setembro e dezembro, enquanto as menores taxas nesses meses foram encontradas no tanque da Embrapa Hortaliças (Figura 6). O reservatório do St. Cachoeira apresentou as maiores taxas de isolamento nos meses de junho $(58,63 \%)$ e agosto $(54,63 \%)$, porém, com exceção de junho, não diferiu estatisticamente do tanque, que apresentou baixas taxas de isolamento nos demais 
meses. O C. Capoeira Grande apresentou altas frequências de recuperação de Pythium entre janeiro e maio.

No meio BARPNH, o reservatório do St. Cachoeira apresentou as maiores taxas de detecção de Pythium nos meses de janeiro, junho e agosto. Já a nascente obteve a maior taxa em setembro, sendo estatisticamente igual aos demais locais de outubro a junho, ocorrendo uma redução na frequência em julho e agosto. O C. Roncador é estatisticamente igual aos locais que apresentam as maiores taxas de isolamento em todos os meses.
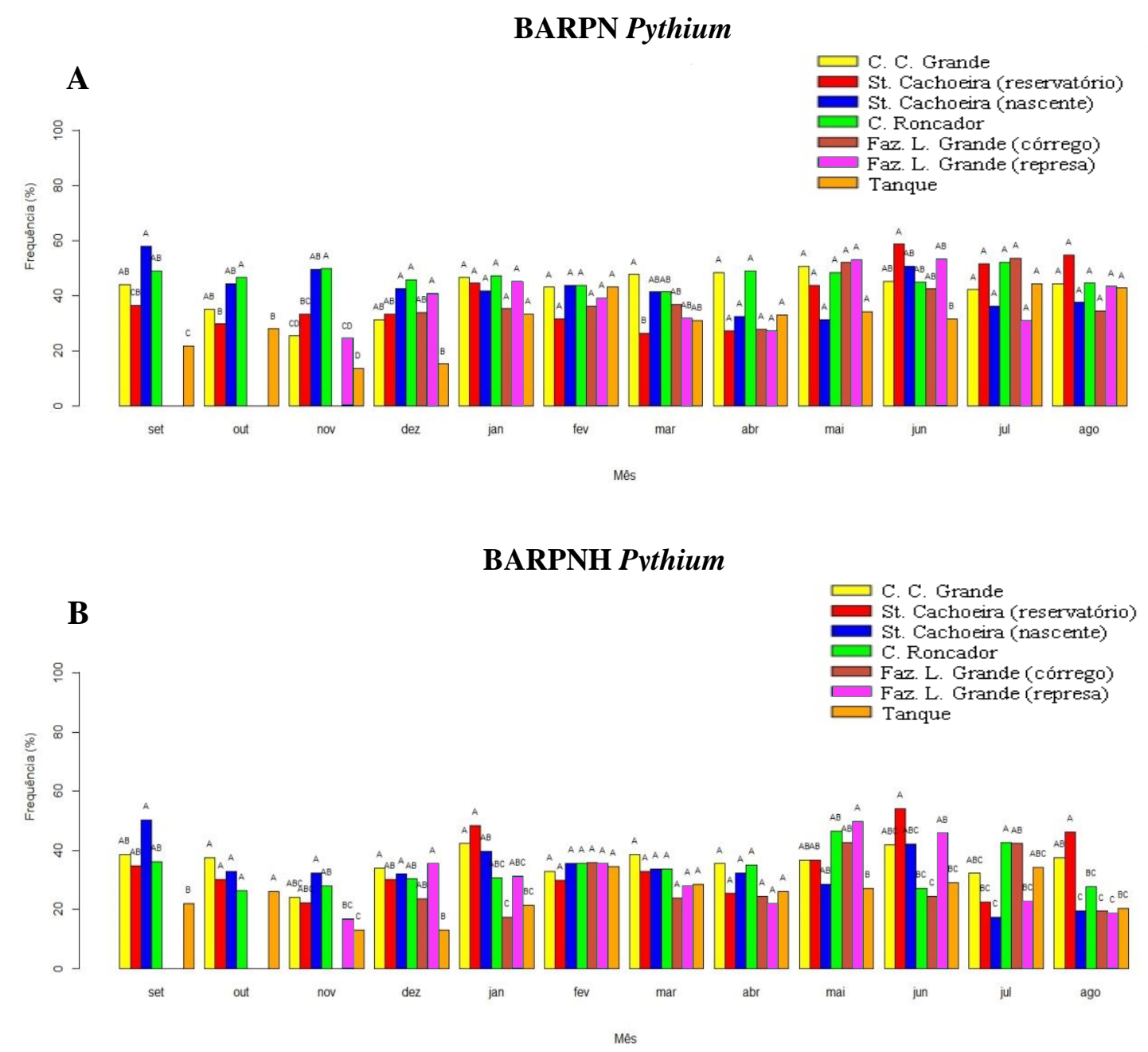

Figura 6. Frequência de isolamento de Pythium spp. no meio BARPN (A) e BARPNH (B) em cada local de amostragem durante os meses avaliados (Interação: local x mês). Médias seguidas da mesma letra na coluna em cada mês de coleta não diferem entre si pelo teste de Tukey a 5\%. Meses avaliados: Setembro/2013 a Agosto/2014. 
Como já foi dito anteriormente, a frequência de isolamento de Pythium e Phytophthora na água variou entre diferentes locais de coleta e entre os meses avaliados. De maneira semelhante, Nascimento (2010) descreveu também que existe uma variação sazonal e espacial no isolamento de espécies zoospóricas da água. Em muitos casos, a sazonalidade das espécies tem sido atribuída a variação dos fatores ambientais (Prabhuji, 2011).

Apesar de mudanças de temperatura e $\mathrm{pH}$ poderem determinar a ocorrência de algumas espécies em fontes de água, os fatores abióticos avaliados pareceram não afetar a taxa de isolamento de Pythium e Phytophthora como foi demonstrado também por Hallett \& Dick (1981) e Nascimento (2010). As diferenças encontradas no isolamento de oomicetos da água são observadas de maneira irregular entre os meses de coleta, não correspondendo à mesma variação encontrada nos fatores abióticos mensurados neste estudo (Figura 7 e 8). Assim, espécies que crescem em altas temperaturas, como Pythium helicoides e Pythium myriotylum, foram encontradas nas fontes de água do Sítio Cachoeira, em que a temperarura média foi aproximadamente $23^{\circ} \mathrm{C}$, demonstrando que essa característica não afetou sua ocorrência.

Apesar desse resultado, a temperatura da água parece ser um dos principais fatores que afeta a sobrevivência e a ocorrência de oomicetos em fontes de água (Koeypudsa et al., 2005). Em alguns casos, a variação da temperatura embasou a formulação de uma classificação das espécies aquáticas segundo a faixa de temperatura em que foram encontradas. Dessa forma, Khulbe \& Bhargava (1977) dividiram as espécies em quatro categorias: espécies constantes, que foram encontradas em temperaturas que variaram de 10 a $28,5^{\circ} \mathrm{C}$, espécies de baixas temperaturas (de 10 a $20^{\circ} \mathrm{C}$ ), espécies de temperaturas moderadas (de 15 a $23,5^{\circ} \mathrm{C}$ ) e espécies de altas temperaturas $\left(15\right.$ a $\left.28,5^{\circ} \mathrm{C}\right)$. Estudando a sazonalidade de fungos aquáticos na Índia, Gupta \& Mehrotra (1989) também distribuíram as espécies em quatro grupos, porém a faixa de temperatura de cada um foi diferente, ou seja, espécies classificadas como de baixas 
temperaturas foram encontradas entre 14,2 e $18^{\circ} \mathrm{C}$, espécies de temperaturas baixas a moderadas, entre 14,2 e $30^{\circ} \mathrm{C}$, espécies de temperaturas moderadas a altas, entre 21,4 e $34,8^{\circ} \mathrm{C}$, e espécies constantes, encontradas na faixa de 14,2 a $34,8^{\circ} \mathrm{C}$. Outros autores agruparam as espécies de acordo com a ocorrência em determinadas estações do ano, em que existe uma amplitude térmica assim como uma estação chuvosa definida (Chowdhry \& Agarwal, 1980; Manoharachary \& Ramarao, 1981).

Nos locais que apresentaram em média as menores temperaturas, variando de 19 a $23^{\circ} \mathrm{C}$, foi possível a recuperação de um maior número de isolados de Pythium e Phytophthora, com exceção do córrego na Faz. L. Grande (Figura 5 e 6). Khulbe \& Bhargava (1977), também observaram um pico na ocorrência de oomicetos em períodos em que as temperaturas variaram de 17,5 a $23,5^{\circ} \mathrm{C}$ em lagos em Nainital (Índia). Igualmente, Srivastava (1967) observou que a maior taxa de detecção de fungos aquáticos em Gorakhpur (Índia) ocorreu nessa mesma amplitude térmica. De acordo com Gupta \& Mehrota (1989), temperaturas acima de $30^{\circ} \mathrm{C}$ inibiram o crescimento e a ocorrência de fungos aquáticos, enquanto temperaturas baixas a moderadas favoreceram a microbiota presente na água.

A maioria dos trabalhos de ecologia de oomicetos em ambientes aquáticos é conduzida em zonas temperadas em que, principalmente, a variação da temperatura entre as estações do ano é muito grande, tornando-se mais fácil notar o efeito de determinado fator sobre a frequência de detecção de diferentes espécies zoospóricas em um período (Rooney \& MacKnigth, 1972; Suzuki, 1981; Czeczuga et al 2002; Marano et al., 2008). No entanto, na maioria dos locais de coleta avaliados neste estudo, a amplitude térmica, assim como a variação de pH e de absorbância da água, durante os doze meses de coleta foi muito pequena, dificultando a comparação entre os meses e o esclarecimento da influência das condições climáticas sobre a dinâmica populacional de oomicetos na água. Devido à pequena diferença 
de temperatura entre estações do ano na Nigéria, Alabi (1971) atribuiu a sazonalidade de fungos na água às estações chuvosas ou secas que ocorreram durante a amostragem.

Da mesma forma que a temperatura, nenhuma relação entre a variação da absorbância e do $\mathrm{pH}$ e a variação na frequência de isolamento de oomicetos foi observada. Segundo Gleason et al. (2009), muitos microrganismos que habitam fontes de água permanecem no estágio dormente, tolerando a queda ou aumento de pH. Pires-Zottarelli (1990) e SchoenleinCrucius \& Milanez (1996) também encontraram diversos fungos zoospóricos em uma ampla faixa de $\mathrm{pH}$, concluindo que esses fungos são resistentes à condições adversas.

Além de todos os fatores abióticos que podem afetar a distribuição de oomicetos na água, Klich e Tiffany (1985) acreditam também que algumas espécies de Saprolegnia foram isoladas em determinados meses do ano provavelmente porque essas espécies não habitam ecossistemas aquáticos permanentemente, mas são provenientes do solo ou de plantas adjacentes à agua, não possuindo a capacidade de sobreviver e reproduzir nesse ambiente. Por outro lado, as espécies vegetais utilizadas como isca podem não ter sido atrativas à essas microrganismos ou terem sido colonizadas por espécies mais competitivas, sendo que a detecção pode ter ocorrido nos meses em que a concentração de propágulos era alta (Hong et al., 2002). Essas podem ser possíveis explicações para o fato das espécies Pythium graminicola, Pythium myriotylum, Phytophthora quininea e Phytophthora macrochlamydospora serem encontradas somente em dois ou três meses de coleta (Tabela 5, capítulo 2).

Outro fator importante seria identificar a fonte de inóculo para entender a ocorrência das espécies em fontes de água (Dick, 1976). Willoughby (1962) demonstrou que quanto maior a distância entre a origem do inoculo e a fonte de água estudada, menor é a frequência de detecção, aumentando, principalmente, em estações chuvosas, em que os propágulos são carreados com o escoamento da água da chuva. 
No caso de $P$. helicoides, que foi isolado em praticamente todos os meses na nascente localizada no St. Cachoeira (Tabela 5), existe o indicativo de que essa espécie possui sazonalidade definida e pode ser um membro permanente da flora aquática nesse local (Klich, 1980; Klich \& Tiffany, 1985). O resultado negativo apenas em alguns meses pode não corresponder à ausência da espécie na água, mas pode ser resultado da competição com outras espécies pelo tecido vegetal da isca (Holtje, 1943).

Apesar de todas essas considerações, existe uma grande complexidade nos processos que ocorrem em fontes de água, como interações entre espécies, tornando difícil avaliar o efeito de determinado fator abiótico sobre a dinâmica populacional desses oomicetos (Reeser et al., 2011). 


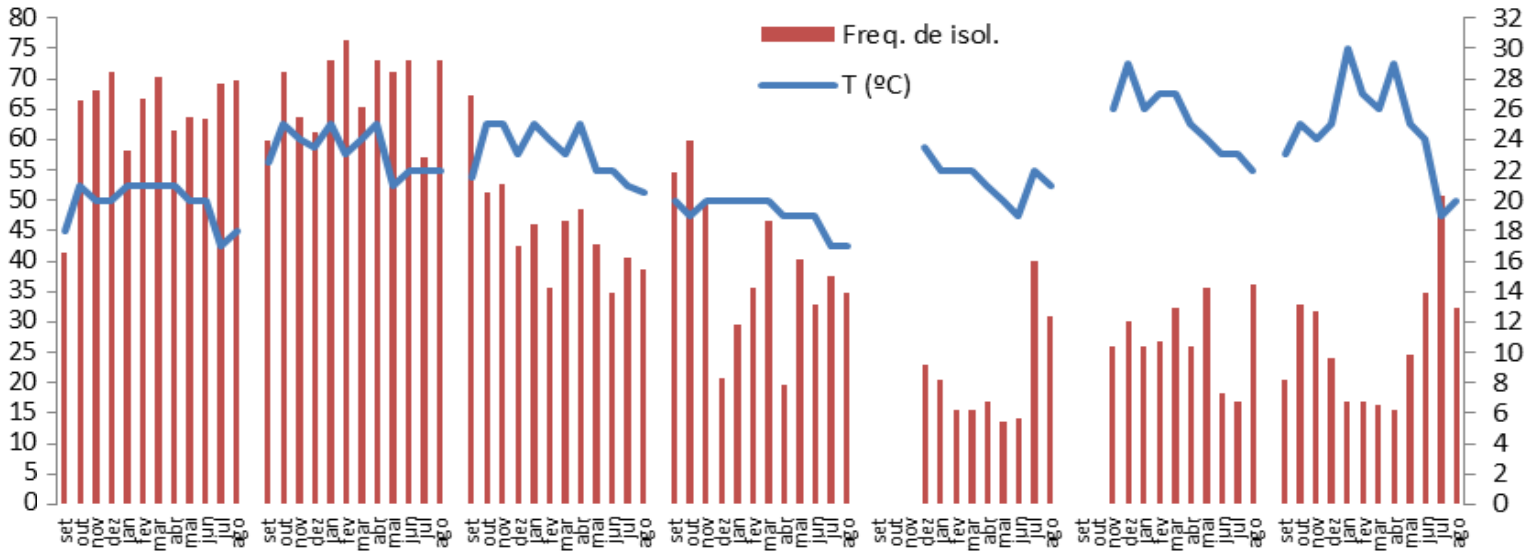
C. C. Grande
reservatório nascente
St. Cachoeira
C. Roncador
córrego Faz. L. Grande
Tanque

(\%) B

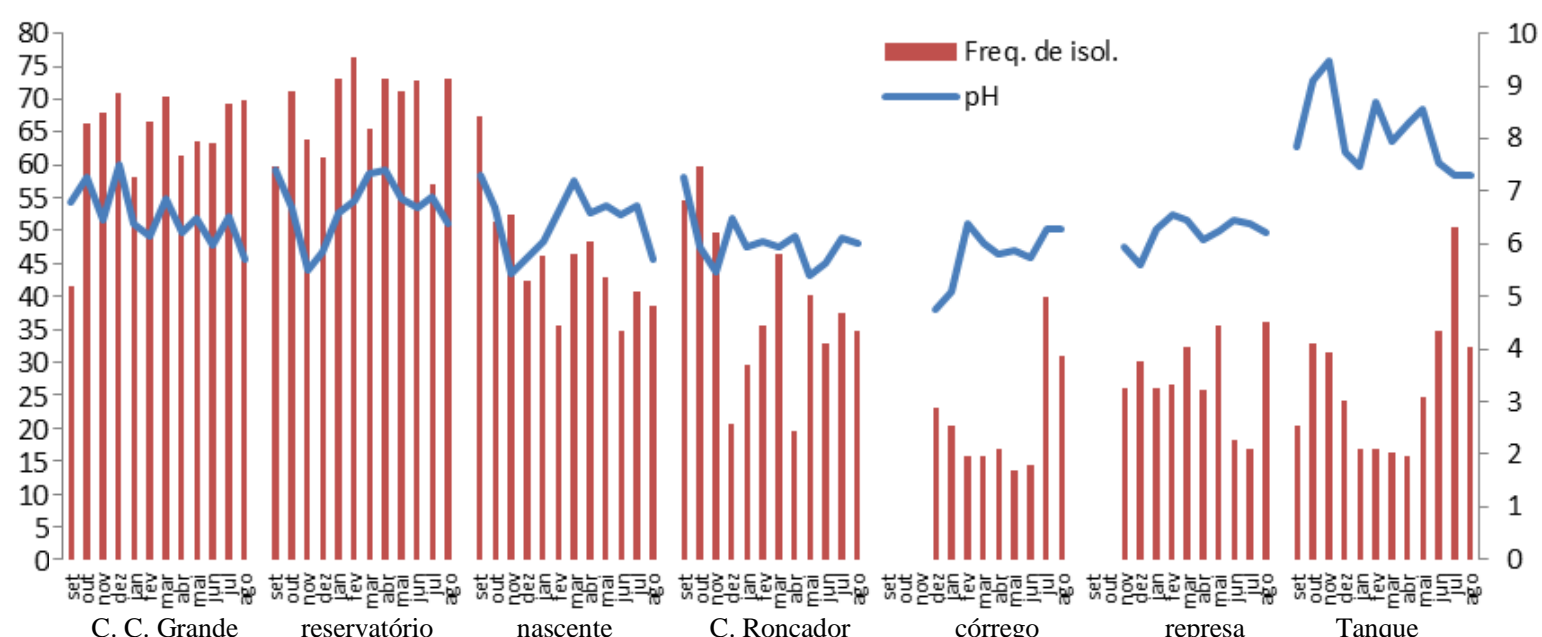
(\%) C St. Cachoeira C. Roncador

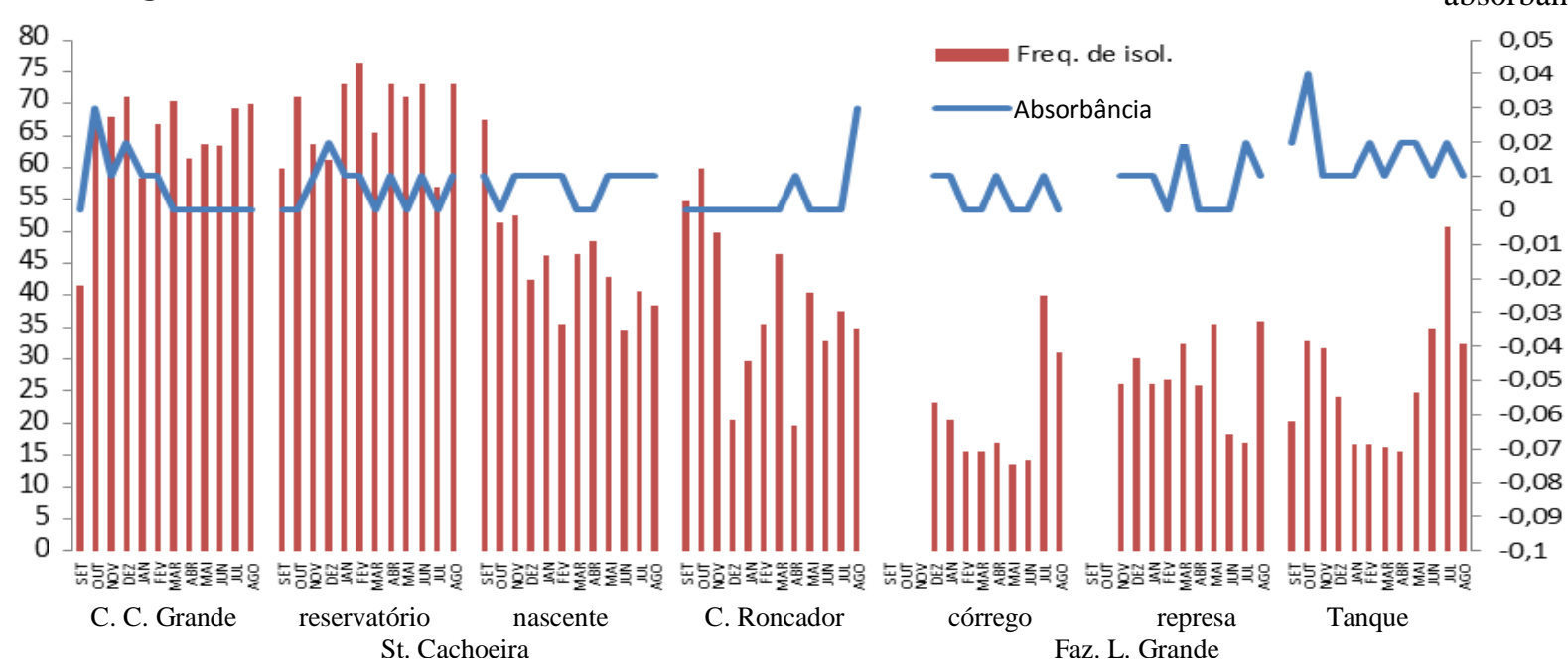

Figura 7. Frequência de isolamento de Phytophthora spp. (\%) no meio BARPN em cada local de coleta e a variação nos fatores abióticos, temperatura (A), pH (B) e absorbância (C) entre os meses de setembro/2013 a agosto/2014. Gráfico de barras representa a frequência de isolamento e o gráfico de linha representa o fator abiótico avaliado. 


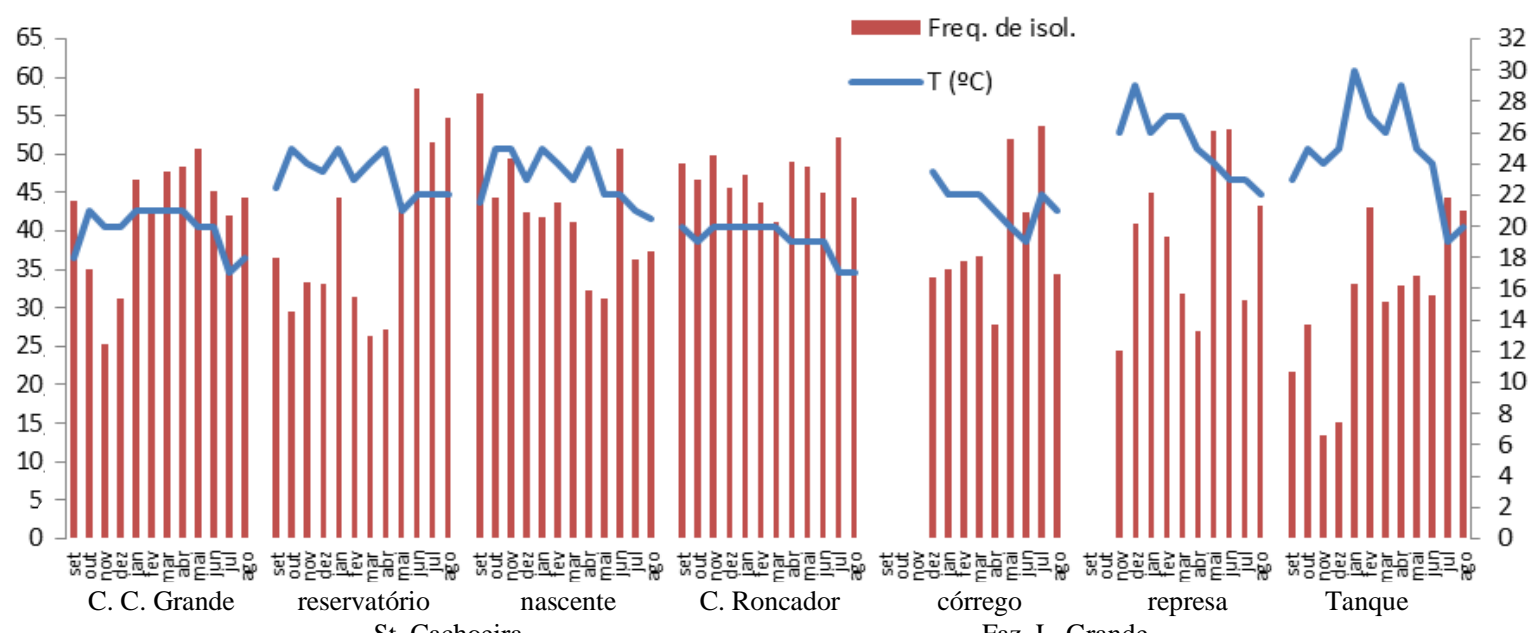

(\%)

B St. Cachoeira Faz. L. Grande
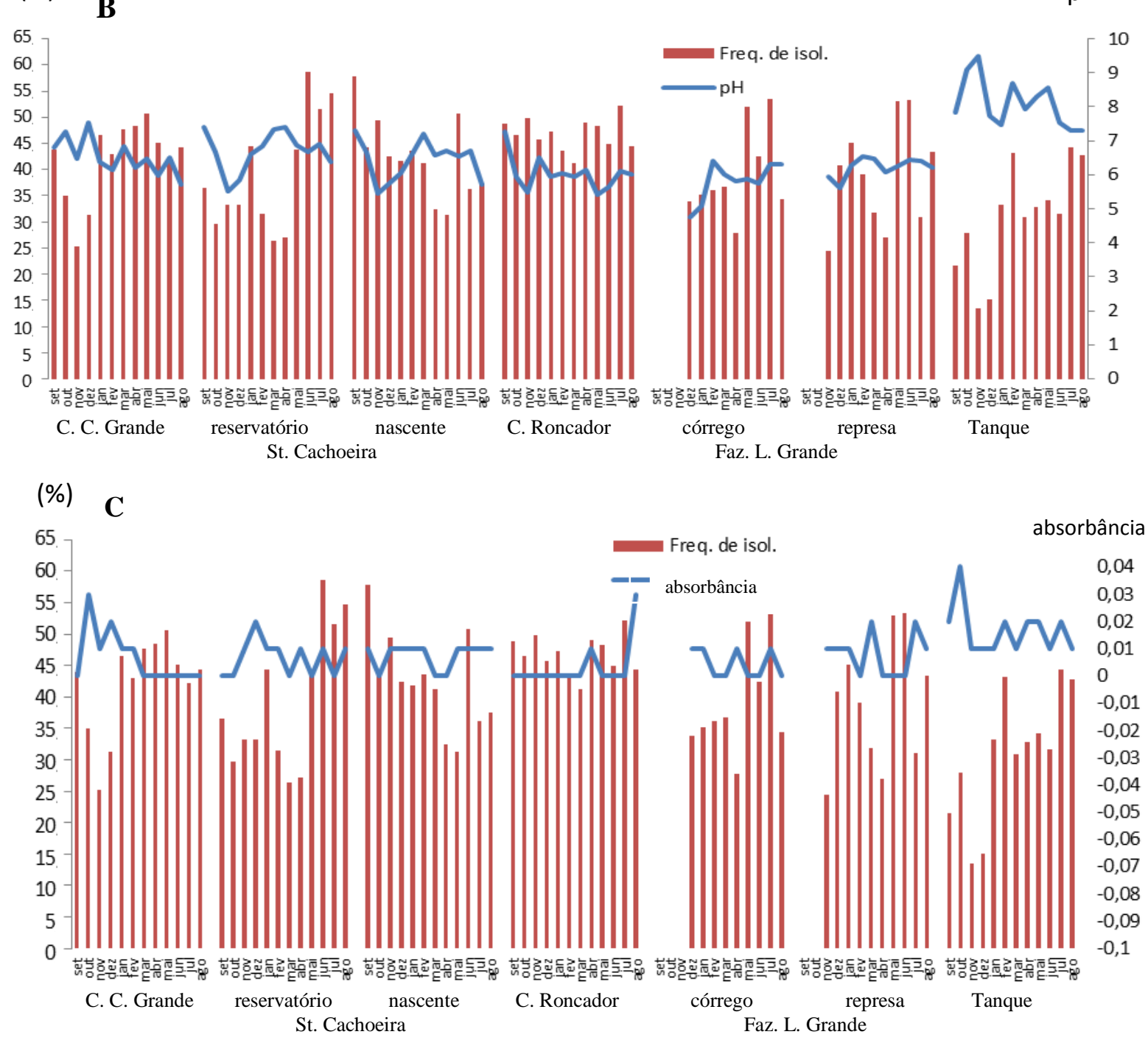

Figura 8. Frequência de isolamento de Pythium spp. (\%) no meio BARPN em cada local de coleta e a variação nos fatores abióticos, temperatura (A), $\mathrm{pH}$ (B) e absorbância (C) entre os meses de setembro/2013 a agosto/2014. Gráfico de barras representa a frequência de isolamento e o gráfico de linha representa o fator abiótico avaliado. 
Todas as iscas foram capazes de detectar Pythium spp. e Phytophthora spp., porém houve variação nas frequências de detecção, confirmando que cada espécie vegetal exerceu níveis de atração diferentes para os oomicetos presentes na água, confirmando dados da literatura (Erwin \& Ribeiro, 1996, Sánchez et al., 2000). Assim, a hipótese de que não existe diferença significativa entre as iscas em cada meio de cultura foi rejeitada $(\mathrm{p}<0,0001)$.

Para os dois meios de cultura, somente as folhas de tomate e capim possibilitaram uma maior recuperação de isolados de Pythium que de Phytophthora, mesmo não havendo diferença estatística entre os gêneros no meio BARPNH para as folhas de capim. As demais espécies vegetais foram melhores para a detecção de Phytophthora tanto no meio BARPN como no meio BARPNH (Tabela 4).

Tabela 4. Frequência de detecção (\%) de Phytophthora spp. e Pythium spp em cada espécie vegetal utilizada como isca.

\begin{tabular}{cccccc}
\hline \multirow{2}{*}{ Iscas } & \multicolumn{2}{c}{ BARPN } & \multicolumn{2}{c}{ BARPNH } & \multirow{2}{*}{ Média } \\
\hline Tomate & $50,49 \mathrm{bA}$ & $66,81 \mathrm{aA}$ & $50,13 \mathrm{bA}$ & $54,27 \mathrm{aA}$ & 55,43 \\
Capim & $41,62 \mathrm{bB}$ & $55,42 \mathrm{aB}$ & $38,10 \mathrm{aC}$ & $41,50 \mathrm{aB}$ & 44,16 \\
Manga & $47,28 \mathrm{aA}$ & $30,21 \mathrm{bC}$ & $48,79 \mathrm{aA}$ & $23,88 \mathrm{bC}$ & 37,54 \\
Palmeira & $40,55 \mathrm{aB}$ & $29,57 \mathrm{bC}$ & $41,61 \mathrm{aB}$ & $22,53 \mathrm{bCD}$ & 33,57 \\
Citros & $39,54 \mathrm{aB}$ & $25,22 \mathrm{bD}$ & $37,15 \mathrm{aC}$ & $20,18 \mathrm{bDE}$ & 30,52 \\
Pinos & $29,05 \mathrm{aC}$ & $17,29 \mathrm{bE}$ & $26,27 \mathrm{aD}$ & $17,45 \mathrm{bE}$ & 22,52 \\
Média & 41,42 & 37,42 & 40,34 & 29,97 & \\
\hline
\end{tabular}

Médias seguidas de letras iguais, maiúsculas na coluna e minúscula na linha para o mesmo meio de cultura, não diferem entre si pelo teste de Tukey a $5 \%$.

Meio de cultura BARPN: meio V8 clarificado com Benomyl, Nistatina, Rifampicina, Ampicilina e Pentacloronitrobenzeno. Meio de cultura BARPNH: meio BARPN + Hymexazol.

Da mesma forma, rejeitamos a hipótese de que não existe diferença estatística entre as iscas em cada local de coleta e em cada mês para um mesmo meio de cultura.

Tanto no meio BARPN como no BARPNH, as folhas de tomate e manga apresentaram as maiores frequências de recuperação de isolados de Phytophthora da água, 
aproximadamente $50 \%$ e $48 \%$, respectivamente, não havendo diferença estatística entre as mesmas (Tabela 4). Nos dois pontos de amostragem da Faz. L. Grande não houve diferença significativa entre as iscas para nenhum dos dois meios de cultura avaliados (Figura 9). No meio BARPNH, o uso de folhas de manga e tomate para a recuperação de Phytophthora da água também foi eficiente. No córrego da Faz. L. Grande e no reservatório do St. Cachoeira, as folhas de palmeira tampém foram consideradas boas iscas para a detecção de Phytophthora, não diferindo estatisticamente de folhas de manga.

Apesar das folhas de citros não diferirem estatisticamente das folhas de capim nos dois meios de cultura e das folhas de palmeira no meio BARPNH, a frequência de recuperação de isolados de Phytophthora em folhas de citros foi baixa comparada às demais espécies vegetais, com exceção das acículas de pinheiro. Dessa forma, mesmo as folhas de citros sendo eficientes na detecção de Phytophthora em amostras de solo (Grimm \& Alexander, 1973), o mesmo resultado não foi observado para as espécies presentes na água dos locais amostrados.

Considerando os meios de cultura testados, tanto para Phytophthora como para Pythium, as acículas de pinus foram as iscas menos atrativas, resultando nas menores taxas de isolamento (Figuras 9 e 10). No trabalho realizado por Sánchez et al. (2000), entre os materiais utilizados como iscas em amostras de água previamente infestadas com espécies de Pythium, foi necessário maior tempo de exposição para que as acículas de pinos fossem capazes de detectar as espécies presentes. Esse resultado corrobora o de Rooney \& McKnight (1972). Esses autores acreditam que as acículas de pinos necessitam de maior tempo na água para que ocorra a decomposição da camada externa das acículas que impede a colonização por espécies aquáticas. Essa espécie vegetal também apresentou como inconvenientes a menor superfície de contato com o meio de cultura e a dificuldade de observação das lesões 
decorrentes da colonização pelos oomicetos. Em razão de todas essas limitações, as acículas de pinos deixaram de ser utilizadas como isca a partir de janeiro de 2014.

\section{BARPN Phytophthora}
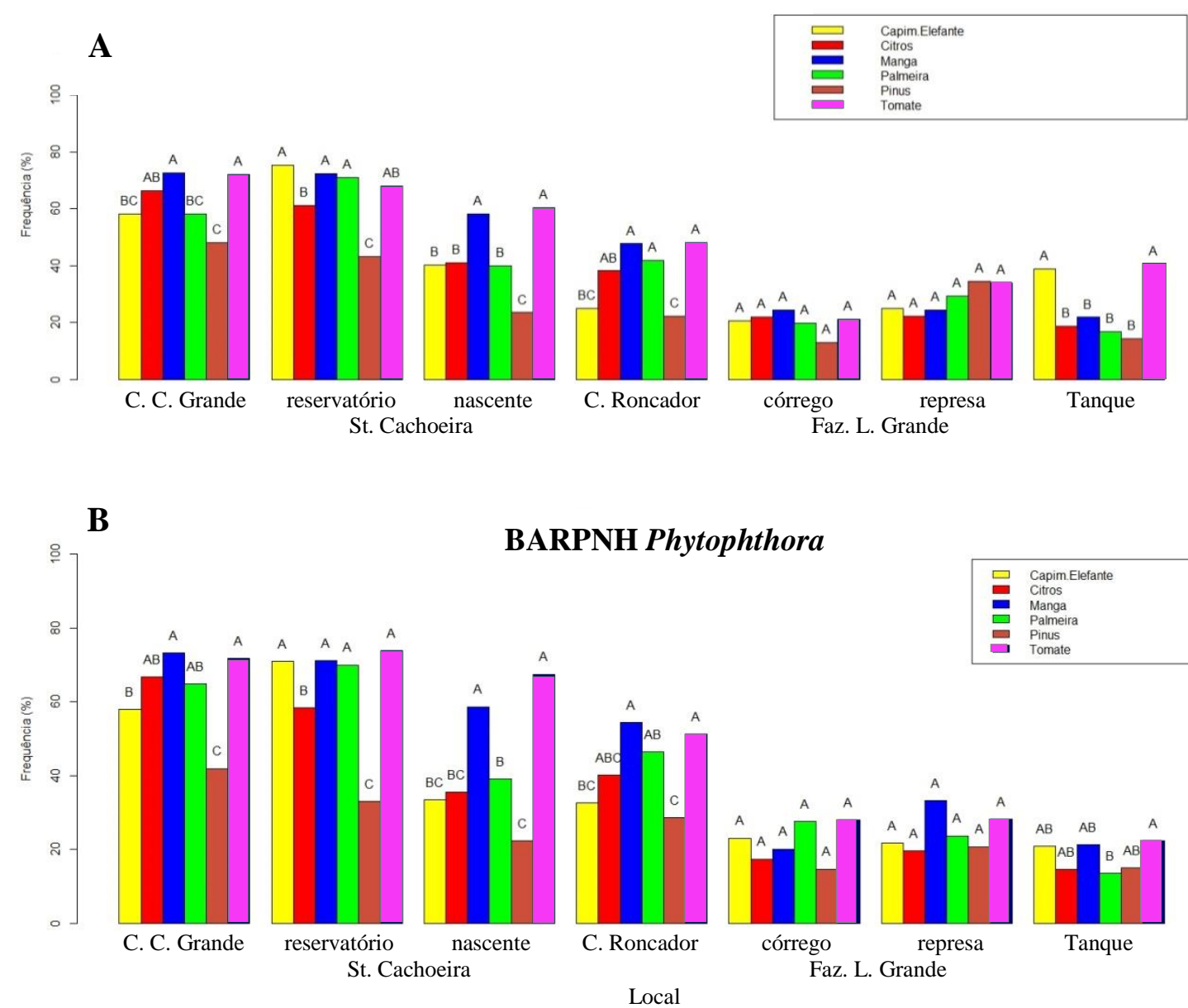

Figura 9. Frequência de isolamento de Phytophthora spp. no meio BARPN (A) e BAPRNH (B) nas espécies vegetais utilizadas como isca em cada local de coleta (Interação: local x isca). Médias seguidas da mesma letra na coluna em cada local de coleta não diferem entre si pelo teste de Tukey a $5 \%$.

Para Pythium, apesar de haver diferença estatística entre a taxa de isolamento de folhas de tomate e capim elefante, estas duas iscas foram significativamente melhores que as demais nos dois meios de cultura ( $\mathrm{p}<0,0001$ ), possibilitando uma frequência de isolamento de $66,8 \%$ e 55,41\% no meio BARPN e 54,2\% e 41,5\% no meio BARPNH, respectivamente (Tabela 4). Esse mesmo resultado foi observado em todos os locais de coleta e durante os doze meses (Figuras 10 e 12). Folhas de capim são comumente utilizadas como isca para o isolamento de 
espécies de Pythium em amostras de solo e de água, auxiliando também a indução de estruturas propagativas para a identificação taxonômica dentro do gênero (van Der PlaatsNiterink, 1981). Além disso, a eficiência do uso de capim na detecção de baixas concentrações de propágulos de espécies de Pythium na água de sistemas hidropônicos e sistemas de irrigação de viveiros também já foi comprovada por Watanabe et al. (2008).

Apesar do isolamento das folhas de tomateiro ser dificultado pela rápida deterioração do limbo foliar, que possivelmente não ocorreria com a redução do tempo de exposição e não afetaria a detecção, essa espécie vegetal destacou-se como uma excelente isca para a detecção de Phytophthora e Pythium, apresentando frequências de isolamento altas, independente do local de coleta e do mês avaliado.

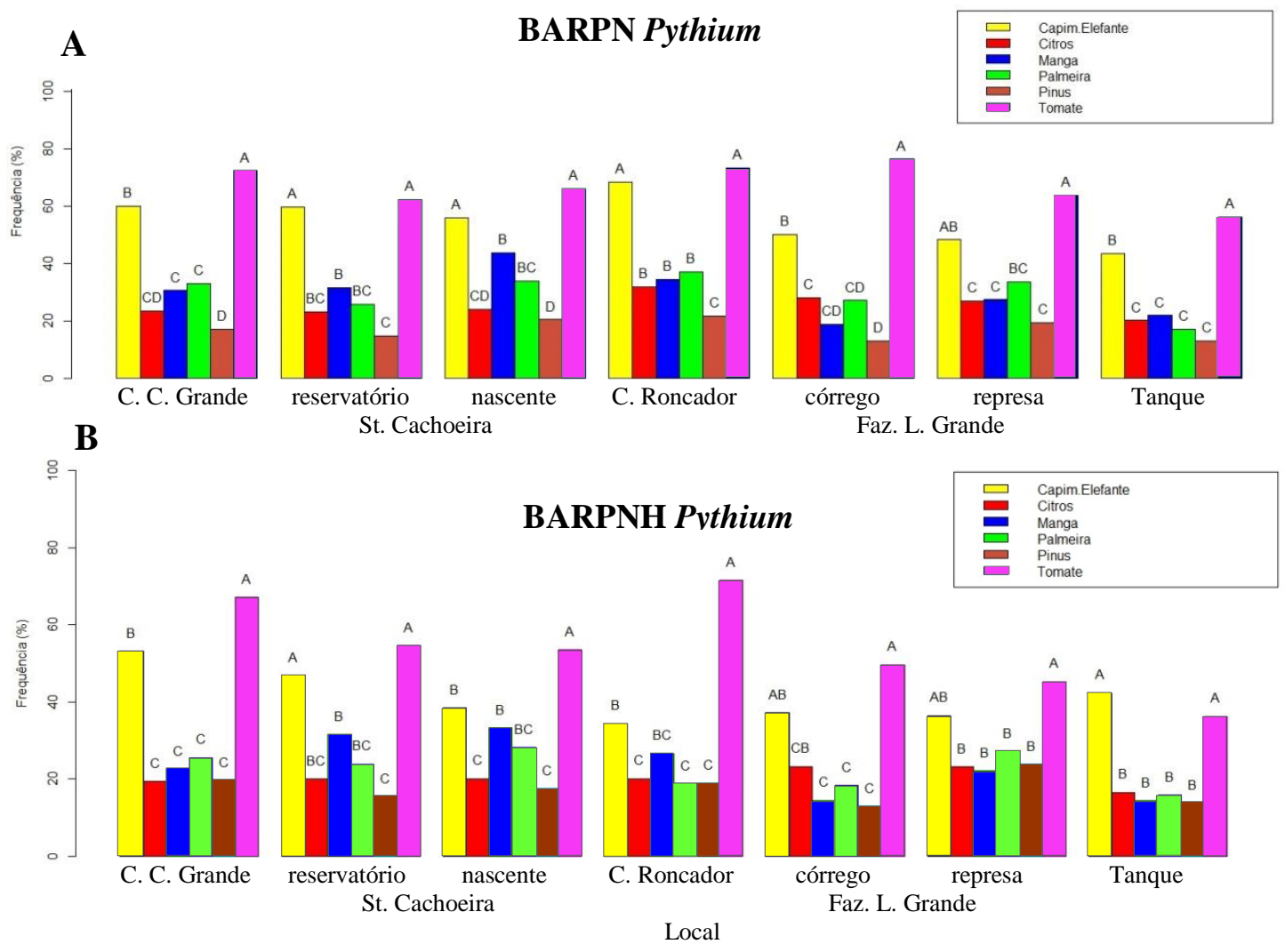

Figura 10. Frequência de isolamento de Pythium spp. no meio BARPN (A) e BAPRNH (B) nas espécies vegetais utilizadas como isca em cada local de coleta (Interação: local x isca). Médias seguidas da mesma letra na coluna em cada local de coleta não diferem entre si pelo teste de Tukey a $5 \%$. 

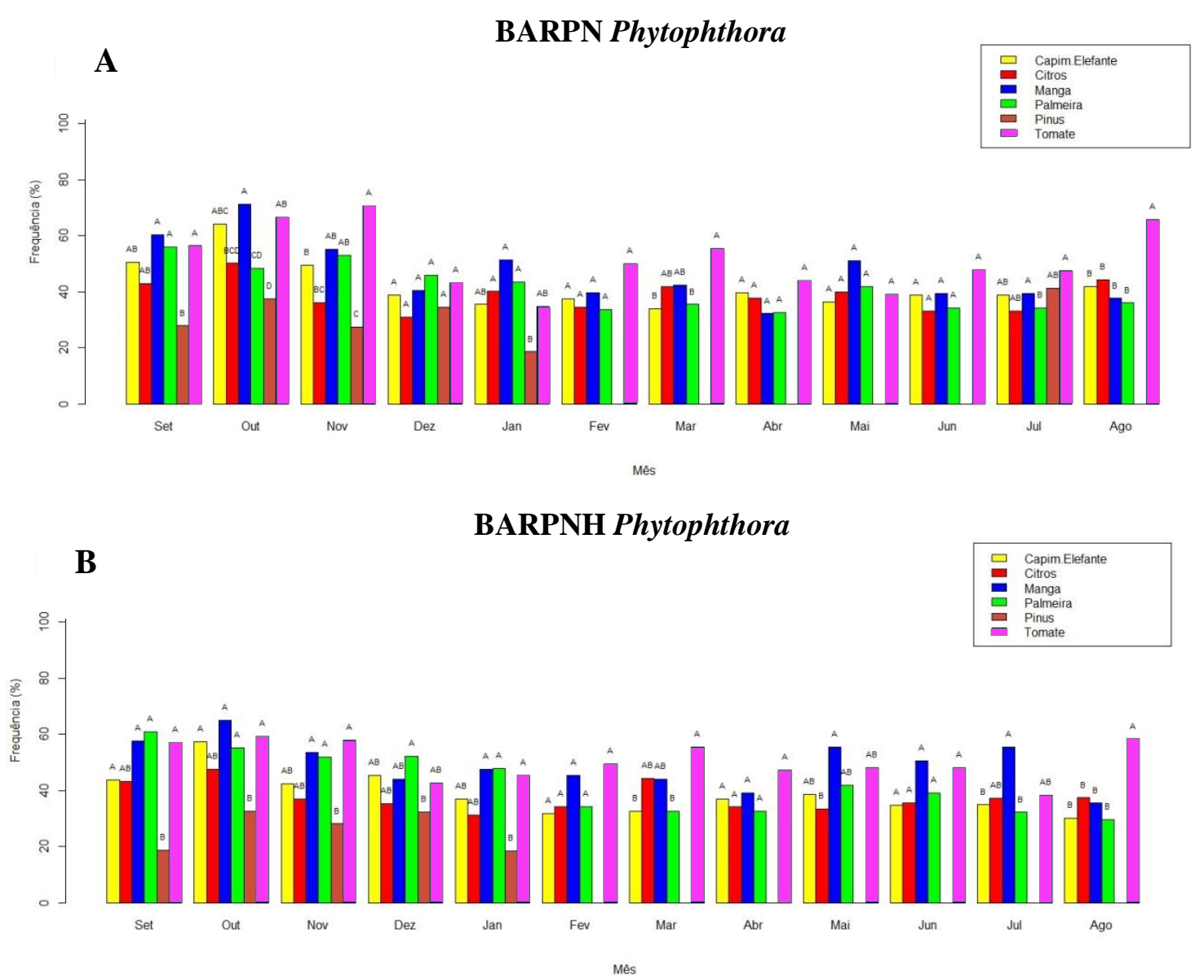

Figura 11. Frequência de isolamento de Phytophthora spp. no meio BARPN (A) e BARPNH (B) nas espécies vegetais utilizadas como isca em cada mês de coleta (Interação: local $\mathrm{x}$ isca). Médias seguidas da mesma letra na coluna em cada mês de coleta não diferem entre si pelo teste de Tukey a 5\%. Meses avaliados: setembro/2013 a agosto/2014. 


\section{BARPN Pythium}

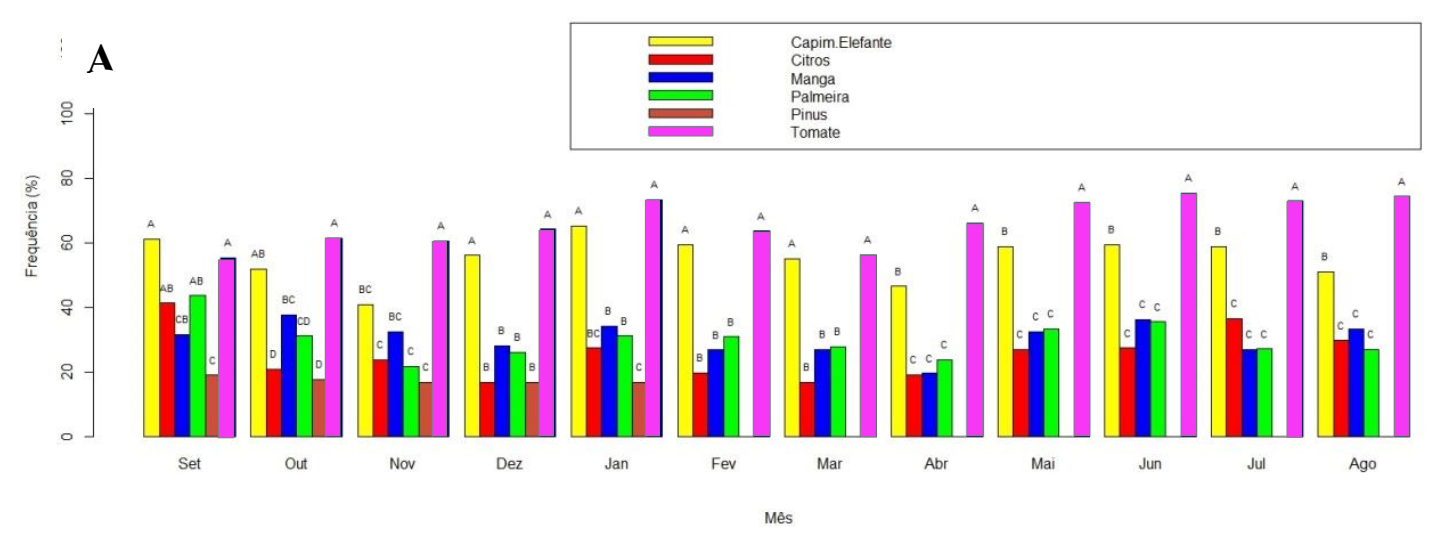

BARPNH Pythium

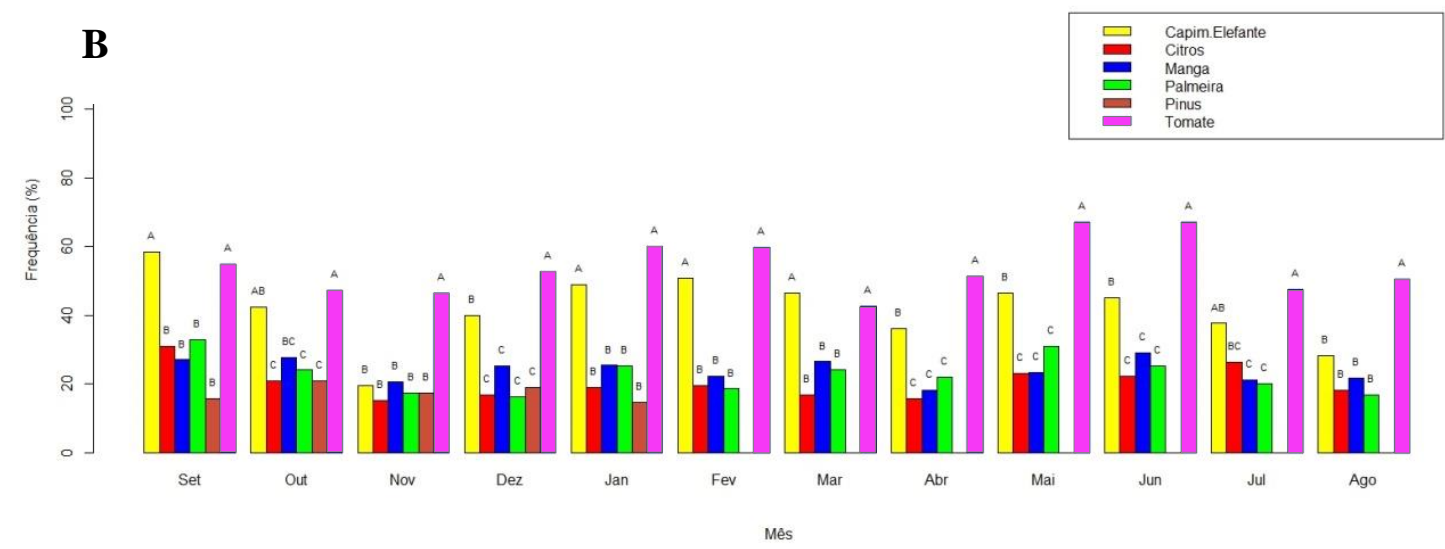

Figura 12. Frequência de isolamento de Pythium spp. no meio BARPN (A) e BARPNH (B) nas espécies vegetais utilizadas como isca em cada mês avaliado (Interação: mês x isca). Médias seguidas da mesma letra na coluna em cada mês de coleta não diferem entre si pelo teste de Tukey a 5\%. Meses avaliados: setembro/2013 a agosto/2014.

Espécies de Phytophthora e Pythium são frequentemente introduzidas em áreas cultivadas a partir de ecossistemas naturais, causando consideráveis perdas econômicas (Nechwatal et al, 2013). O conhecimento da presença desses oomicetos na água de irrigação e dos fatores que favorecem seu estabelecimento podem fornecer subsídios ao desenvolvimento de estratégias de manejo de doenças de plantas (Hong \& Moorman, 2005). Apesar dos fatores abióticos avaliados não serem determinantes na sazonalidade das espécies recuperadas de fontes de água neste estudo, outras características físicas e químicas da água, em conjunto com a temperatura, o pH e a absorbância, podem desempenhar papel relevante na variação 
espacial e temporal desses oomicetos em ecossistemas aquáticos, tornando-se importante avaliar o efeito de outras variáveis climáticas sobre a atividade dos microrganismos em um período maior de tempo.

Outro fator importante é a disponibilidade de métodos de detecção rápidos e sensíveis e que permitam um conhecimento da diversidade existente na água. Nesse sentido, folhas de tomateiro parecem não ser afetadas pela variação nos fatores abióticos e nem pelas diferentes características encontradas em cada local, mostrando-se promissoras como iscas para a detecção de Pythium e Phytophthora na água de irrigação. No entanto, quando se pretende recuperar diferentes espécies da água, o uso de um único tipo de isca pode restringir a taxa de detecção a determinados organismos, já que nem todas as espécies de oomicetos encontradas neste trabalho colonizaram as folhas de tomateiro. Esse fato fornece indícios da necessidade do uso de mais de uma espécie vegetal como isca para uma melhor compreensão da diversidade existente e para o monitoramento de fitopatógenos em fontes de água de irrigação (Ferguson \& Jeffers, 1999). 


\section{CONCLUSÕES DO CAPÍTULO}

- As frequências de isolamento de Pythium e Phytophthora da água de irrigação foram diferentes em cada local de coleta de acordo com o mês avaliado;

- A amplitude de variação observada nos fatores abióticos avaliados não foi determinante na variação da frequência de isolamento observada para cada gênero;

- A recuperação dos isolados de Phytophthora foi praticamente a mesma nos dois meios de cultura, ou seja, a adição de Hymexazol não melhorou a detecção de Phytophthora, enquanto para Pythium spp., a frequência de detecção foi maior no meio BARPN;

- As folhas de tomateiro foram as melhores iscas para a detecção de Phytophthora e Pythium na água;

- Folhas de manga e capim também foram eficientes para a recuperação de Phytophthora e Pythium da água, respectivamente, mas a frequência de isolamento nessas duas iscas variou muito mais de acordo com o mês e o local de coleta;

- As iscas com menor potencial para a detecção de oomicetos em ambientes aquáticos foram as acículas de pinheiro e as folhas de citros. 


\section{REFERÊNCIAS BIBLIOGRÁFICAS}

ALABI, R.O. 1971. Factors affecting seasonal occurrence of Saprolegniaceae in Nigeria. Transactions of the British Mycological Society, 56(2): 289-299.

BUSH, E.A. 2002. Characterization of Phytophthora species in recycled irrigation water at a container nursery in Southwestern Virginia. M. S. Thesis, Virginia Polytechnic Institute and State University, Blacksburg, VA.

BUSH, E.A.; HONG, C. \& STROMBERG, E. 2003. Fluctuations of Phytophthora and Pythium spp. in components of a recycling irrigation system. Plant Disease, 87(12): 15001506.

CHOWDHRY, P.N. \& AGARWAL, G.P. 1980. Studies on distribution of some aquatic fungi in India. Note. Indian Phytopathology, 33: 107-109

CLEMENTE, F.M.V.T. \& BOITEUX, L.S. (eds). 2012. Produção de tomate para processamento industrial. Brasília: Embrapa Hortaliças. 344p.

COOKE, W.B. 1961. Pollution effect on the fungus population of a stream. Journal of Ecology. 42: 1-18.

CZECZUGA, B.; KIZIEWICZ, B.; GODLEWSKA, A. \& ORŁOWSKA, M. 2002. Further studies on aquatic fungi in the river Narew within the Narew National Park. Roczniki Akademii Medycznej w Bialymstoku, 47:58-79.

DICK, M.W. 1976. The ecology of aquatic Phycomycetes. In: GARETH JONES, E. B. (ed.). Recent Advances in Aquatic Mycology. Elek Science, London: 513-542.

ERWIN, D.C. \& RIBEIRO, O.K. 1996. Phytophthora Diseases Worldwide. APS Press, St. Paul, Minnesota.

FAOSTAT. 2012. http://faostat.fao.org/site/339/default.aspx Consultado em: julho/2014.

FERGUSON, A.J. \& JEFFERS, S.N. 1999. Detecting multiple species of Phytophthora in container mixes from ornamental crop nurseries. Plant Disease. 83:1129-1136.

FREITAS, M.A.; NASSER, L.C.B. \& CAFÉ FILHO, A.C. 2001. Água contaminada: fitopatógenos infestam a água. Cultivar $H F$, 8:32-37.

GHIMIRE, S.R.; RICHARDSON, P.A.; MOORMAN, G.W.; LEA-COX, J.D.; ROSS, D.S. \& HONG, C.X. 2009. An in-situ baiting bioassay for detecting Phytophthora species in irrigation runoffcontainment basins. Plant Pathology, 58(3): 577-583.

GLEASON, F.H.; DAYNES, C.N. \& MCGEE, P.A. 2009. Some zoosporic fungi can grow and survive within a wide $\mathrm{pH}$ range. Fungal Ecology, 3(1): 31-37.

GOMEZ, K.A. \& GOMEZ, A.A. 1984. Statistical procedures for agricultural research. 2nd Ed. John wiley, 704p. 
GRIMM, G.R. \& ALEXANDER, A.F. 1973. Citrus leaf pieces as trap for Phytophthora parasitica from soils slurries. Phytopathology 63:540-541.

GUPTA, A.K. \& MEHROTRA, R.S. 1989. Seasonal periodicity of aquatic fungi in tanks at Kurukshetra, India. Hydrobiologia, 173(3):219-229.

HALLETT, I.C. \& DICK, M.W. 1981. Seasonal and diurnal fluctuations of oomycete propagule numbers in the free water of a freshwater lake. The Journal of Ecology, 69(2): 671692.

HOLTJE, R. J. 1943. The biology of sewage sprinkling filters. Sewage Works J. 15:14-29.

HONG, C.X. \& MOORMAN, G.W .2005. Plant pathogens in irrigation water: challenges and opportunities. Critical Rewiews in Plant Sciences 24(3): 189-208.

HONG, C.; RICHARDSON, P.A. \& KONG, P. 2002. Comparison of membrane filters as a tool for isolating Pythiaceous species from irrigation water. Phytopathology 92(6): 610-616.

HONG, C.X.; RICHARDON, P.A. \& KONG, P. 2008. Pathogenicity to ornamental plants of some existing species and new taxa of Phytophthora from irrigation water. Plant Disease, 92(8):1201-1207.

IBGE. 2014. Levantamento sistemático da produção agrícola. ftp://ftp.ibge.gov.br/Producao_Agricola/Levantamento_Sistematico_da_Producao_Agricola _[mensal]/Fasciculo/lspa_201401.pdf. Consultado em: julho/2014.

JEFFERS, S.N. \& MARTIN, S.B. 1986. Comparison of two media selective for Phytophthora and Pythium species. Plant Disease, 70: 1038-1043.

KHULBE, R.D. \& BHARGAVA, K.S. 1977. Distribution and seasonal periodicity of water moulds in some lakes in Nainital hills, India. Hydrobiologia, 54(1): 67-72.

KLICH, M.A. \& TIFFANY, L.H. 1985. Distribution and seasonal occurrence of Aquatic Saprolegniaceae in Northwest Iwoa. Mycologia, 77(33):373-380.

KLICH, M.A. 1980. Taxonomy, distribution, and seasonal occurrence of the Saprolegniaceae in aquatic sites in northwest Iowa. Retrospective Thesis and Dissertations. Iowa State University.

KOEYPUDSA, W.; PHADEE P.; TANGTRONGPIROS J. \& HATAI K. 2005. Influence of $\mathrm{pH}$, temperature and sodium chloride concentration on growth rate of Saprolegnia sp. Journal of Scientific Research at Chulalongkorn University, 30(2): 123-130.

KRAUSS, G.J.; SOLÉ, M.; KRAUSS, G.; SCHLOSSER, D.; WESENBERG, D. \& BÄRLOCHER, F. 2011. Fungi in freshwaters: ecology, physiology and biochemical potential. FEMS microbiology reviews, 35(4): 620-651.

KHULBE, R.D. \& BHARGAVA, K.S. 1977. Distribution and seasonal periodicity of water moulds in some lakes of Nainital Hills, India. Hydrobiologia, 54(1): 67-72.

LAUDERDALE, C.C. \& JONES, R.K. 1997. Monitoring irrigation ponds for Phytophthora sp. Proceedings of SNA Research Conference, 42:225-226. 
LIMA, M.G.C.F. 1995. Hidrografia. p. 165-181. In: Zoneamento ambiental da Bacia do Córrego Taquara - DF. Vol II, Goiânia,. MPO/FIBGE. Diretoria de Geociências do CentroOeste - DIGEO/GO.

MANOHARACHARY, C. \& RAMARAO, P. 1981. Seasonal variation and distribution of fungi in two fresh water ponds of Andhra Pradesh, India. Proceedings: Plant Sciences, 90(3): 237-243.

MARANO, A.V.; BARRERA, M.D.; STECIOW, M.M.; DONADELLI, J.L. \& SAPARRAT, M.C. 2008. Frequency, abundance and distribution of zoosporic organisms from Las Cañas stream (Buenos Aires, Argentina). Mycologia, 100(5), 691-700.

MASAGO, H.; YOSHIKAWA, M.; FUKADA, M. \& NAKANISHI, N. 1977. Selective inhibition of Pythium spp. from soils and plants. Phytopathology 67(3): 425-428.

MILANEZ, A.I. 1970. Contributions to the knowledge of aquatic Phycomycetes of São Paulo State, I: Oomycetes form the west region. Rickia 5: 23-43.

MIRANDA, M.L. \& PIRES-ZOTTARELLI, C.L.A. 2008. O gênero Pythium no Parque Estadual da Serra da Cantareira, estado de São Paulo, Brasil. Hoehnea 35: 281-288.

NASCIMENTO, C.A. \& PIRES-ZOTTARELLI, C.L.A. 2012. Diversidade de fungos zoospóricos da Reserva Biológica de Mogi Guaçu, estado de São Paulo, Brasil. Rodriguésia 63(3): 587-611

NASCIMENTO, C.A. 2010. Avaliação da diversidade de organismos zoospóricos da Reserva Biológica e Estação Experimental de Mogi Guaçu, Estado de São Paulo, Brasil. Tese de Doutorado. Instituto de Botânica da Secretaria de Estado do Meio Ambiente. São Paulo, Brasil.

NASCIMENTO, C.A.; GOMES, E.P.C. \& PIRES-ZOTTARELLI, C.L.A. 2011. Occurrence and distribution of zoosporic organisms in water bodies from Brazilian Cerrado. Mycologia, 103(2): 261-272.

NECHWATAL, J. \& MENDGEN, K. 2006. Pythium litorale sp. nov., a new species from the littoral of Lake Constance, Germany. FEMS Microbiology Letter, 255(1): 96-101.

NECHWATAL, J.; BAKONYI, J.; CACCIOLA, S.O.; COOKE, D.E.L.; JUNG, T.; NAGY, Z.A.; VANNINI, A; VETTRAINO, A.M. \& BRASIER, C. M. 2013. The morphology, behaviour and molecular phylogeny of Phytophthora taxon Salixsoil and its redesignation as Phytophthora lacustris sp. nov. Plant Pathology, 62(2), 355-369.

PALIWAL, P. C. \& SATI, S. C. 2009. Distribution of aquatic fungi in relation to physicochemical factors of Kosi river in Kumaun Himalaya. Nature and Science, 7(3): 70-74.

PARKUNAN, V. \& JI, P. 2013. Isolation of Pythium litorale from irrigation ponds used for vegetable production and its pathogenicity on squash. Canadian Journal of Plant Pathology 35(3): 415-423.

PIRES-ZOTTARELLI, C.L.A. 1990. Levantamento dos fungos zoospóricos da Represa do Lobo ("Broa"), São Carlos, SP, Brasil. Dissertação de Mestrado, Universidade Estadual Paulista, São Paulo, SP. 
PRABHUJI, S.K. 2011. The interdependence of watermoulds occurring in water and soil habitats affecting their population density, distribution and periodicity. Tropical Ecology 52(3): 311-324.

PRASAD, D.R.; HOSKERI, J. \& KRISHNA, V. 2009. Diversity of aquatic fungi in relation to environmental conditions in Tunga River (South India). Researcher, 1(6): 54- 62.

REESER, P.W.; HANSEN, E.M. \& SUTTON, W. 2007. Phytophthora siskiyouensis, a new species from soil, water, myrtle wood (Umbellularia californica) and tanoak (LithocarLithocarpus densiflorus) in southwestern Oregon. Mycologia, 99: 639-643.

REESER, P.W.; SUTTON, W.; HANSEN, E.M.; REMIGI, P. \& ADAMS, G.C. 2011. Phytophthora species in forest streams in Oregon and Alaska. Mycologia, 103(1), 22-35.

RIVERO, V.I.; GIAYETTO, A.; ROSSINI, M.; VERA, M. 2010. Detection of Phytophthora cactorum in the irrigation water in Commercial Orchards of 'Bartlett' Pear in Villa Regina, Río Negro, Argentina. In XI International Pear Symposium, 909: 521-526.

ROCHA, M. 2004. Micota zoospórica da lagos com diferentes trofias do parque Estadual dal Fontes do Ipiranga (PEFI) (Master's dissertation). São Paulo, São Paulo: Instituto de Ciências Biomédicas, USP. 85 p.

ROONEY, H.M. \& MCKNIGHT, K.H. 1972. Aquatic phycomycetes of Lily Lake, Utah. Great Basin Naturalist 32:181-189.

ROTEM, J. \& PALTI, J. 1969. Irrigation and plant diseases. Annual Review of Phytopathology, 7(1): 267-288.

SÁNCHEZ, J.; SÁNCHEZ-CARA, J. \& GALLEGO, E. 2000. Suitability of ten plant baits for the rapid detection of pathogenic Pythium species in hydroponic crops. European Journal of Plant Pathology, 106(3): 209-214.

SCHOENLEIN-CRUSIUS, I. H. \& MILANEZ, A. I. 1996. Diversity of aquatic fungi in Brazilian Ecosystems. In: Bicudo, C. \& Menezes, N. A. (eds.). Biodiversity in Brazil: a first approach. CNPq, São Paulo, pp. 31-48.

SHOKES, F.M. \& MCCARTER, S.M. 1979. Occurrence, dissemination, and survival of plant pathogens in surface irrigation ponds in southern Georgia. Phytopathology 69(5):510-516.

SILVA, H. R.; CARRIJO, O.A.; SILVA, J.B.C.; MAROUELLI, W.A.; GUIRAU, L.A.R.; MARINHO, A.G. 2004. Diagnóstico do sistema de irrigação e estruturas hidraúlicas e civis do setor de campos experimentais do Centro Nacional de Pesquisa de Hortaliças. Brasília DF: Embrapa Hortaliças, 39 p. (Documento 66).

SILVA, M.I.L. 2002. Micobiota de água e solo das margens de Igarape's situados na área de mata do campus da Universidade do Amazonas, Manaus, AM, Brasil (Doctoral Dissertation). São Paulo, SP: Instituto de Biociências, USP, SP. 175 p.

SPARROW, F.K. 1968. Ecology of freshwater fungi. In: AINSWORTH GC, SUSSMAN AS, eds. The Fungi vol. 3. New York: Academic Press. p 41-93. 
SRIVASTAVA, G. C. 1967. Ecological studies on some aquatic fungi of Gorakhpur, India. Hydrobiologia 30(3-4): 385-404.

SUTTON, W.; HANSEN, E.M.; REESER, P.W.; KANASKIE, A. 2009. Stream monitoring for detection of Phytophthora ramorum in Oregon tanoak forests. Plant Disease, 93(11): $1182-1186$.

SUZUKI, S. 1981. Characteristics of the distribution of aquatic Phycomycetes in the bottom muds of Japanese lakes. Environmental Pollution Series A, Ecological and Biological, 25(4): 249-257.

THEMANN, K.; WERRES, S.; DIENER, H.A. \& LÜTTMANN, R. 2002. Comparison of different methods to detect Phytophthora spp. in recycling water from nurseries. Journal of Plant Pathology, 84(1): 41-51.

TSAO, P.H. \& GUY, S.O. 1977. Inhibition of Mortierella and Pythium in a Phytophthoraisolation medium containing hymexazol. Phytopathology, 67:796-801

VAN DER PLAATS-NITERINK, A.J. 1981. Monograph of the genus Pythium. Studies in Mycology. No.21. Centraalbureau voor Schimmelcultures, Baarn. 242 pp.

WATANABE, H.; KAGEYAMA, K.; TAGUCHI, Y.; HORINOUCHI, H. \& HYAKUMACHI, M. 2008. Bait method to detect Pythium species that grow at high temperatures in hydroponic solutions.Journal of General Plant Pathology, 74(6): 417-424.

WILLOUGHBY, L.G. 1962. The occurrence and distribution of reproductive spores of Saprolegniales in fresh water. The Journal of Ecology. Ecol. 50(3): 733-759.

WILSON, S.K.; VON BROEMBSEN, S.L.; SMOLEN, M.D. \& ANDREWS, M.W. 1998. Pathogen management in capture and recycle irrigation systems for nurseries. Pages 1-6 (paper no. 98-7004) in: ASAE annual international meeting. Orlando (pp.12.16).

ZAPPIA, R.E; HÜBERLI, D, HARDY, G.E.ST.J. \& BAYLISS, K.L. 2014. Fungi and oomycetes in open irrigation systems: knowledge gaps and biosecurity implications. Plant Pathology. 12p. 


\section{CAPÍTULO 2}

Caracterização morfológica e molecular dos isolados de Pythium e Phytophthora obtidos em fontes de água de irrigação. 


\section{RESUMO}

Pythium e Phytophthora representam dois grandes gêneros dentro da Classe Oomycetes. Durante muitos anos, a identificação das espécies pertencentes a esses dois gêneros foi realizada apenas com base nas características morfológicas. No entanto, a plasticidade desses caracteres e a semelhança observada entre diferentes espécies tem dificultado a separação de táxons próximos. O advento das técnicas moleculares permitiu uma melhor acurácia na caracterização das espécies de fitopatógenos. Dessa forma, o objetivo deste capítulo foi realizar caracterização morfológica, análise molecular e filogenética dos isolados de oomicetos obtidos de fontes de água de irrigação. O sequenciamento da região ITS e a observação das estruturas morfológicas permitiu a identificação de cinco espécies de Pythium: P. helicoides, P. chamaihyphon, P. catenulatum, P. graminicola e P. myriotylum, e duas espécies de Phytophthora: $P$. quininea e $P$. macrochlamydospora. As árvores filogenéticas revelaram que as espécies de Pythium foram agrupadas segundo a morfologia dos esporângios. Dessa forma, P. helicoides e P. chamaihyphon, que possuem esporângios globosos, permaneceram no mesmo clado, enquanto $P$. catenulatum, $P$. graminicola e $P$. myriotylum agruparam com espécies que apresentam esporângios filamentosos. Todos os isolados de Phytophthora agruparam com espécies pertencentes ao clado 9, que inclui a maioria das espécies de Phytophthora encontradas em ambientes aquáticos. Além disso, as espécies que compõem esse clado apresentam esporângios semipapilados ou não papilados, assim como observado na caracterização morfológica das espécies. No teste de patogenicidade, o isolado de $P$. helicoides causou podridão de frutos em todas as repetições testadas. $P$. chamaihyphon também causou podridão em praticamente todos os frutos de tomate inoculados. Para os demais isolados, a reprodutibilidade dos resultados entre os experimentos conduzidos foi baixa, não permitindo inferências sobre a patogenicidade.

Palavras-chave: morfologia, sequenciamento, região ITS, filogenia 


\section{ABSTRACT}

Pythium and Phytophthora are two major genera within the class Oomycetes. For many years, the identification of species belonging to these two genera was conducted based on morphological characteristics. However, the plasticity of these characters and the similarity found between different species has hindered the separation of close taxa. The advent of molecular technique, mainly the Polymerase Chain Reaction (PCR), allowed a better accuracy in the characterization of the species of plant pathogens. Thus, the aim of this chapter was to perform a morphological and molecular characterization, and phylogenetic analysis of oomycetes isolates from sources of irrigation water. The sequencing of the ITS region and the observation of morphological structures allowed the identification of five species of Pythium: P. helicoides, $P$. chamaihyphon, $P$. catenulatum, $P$. graminicola and P. myriotylum, and two species of Phytophthora, $P$. quinine and $P$. macrochlamydospora. Phylogenetic trees revealed that Pythium species were grouped according to the morphology of the sporangia. Thus, $P$. helicoides e $P$. chmaihyphon, that have globose sporangia, grouped in the same clade, while $P$. catenulatum, $P$. graminicola and $P$. myriotylum grouped with species with filamentous sporangia. All isolates of Phytophthora grouped with species belonging to clade 9, which includes most species of Phytophthora found in aquatic environments. Furthermore, the species that compose this clade exhibit semi-papillate or nonpapillate sporangia, as observed in the morphological characterization of the species. In the pathogenicity test, the strain of $P$. helicoides caused fruit rot symptoms in all replicates tested. $P$. chamaihyphon also caused decay in virtually all evaluated fruit. For all other strains, the reproducibility of results between experiments conducted was low.

Keywords: morphology, sequencing, ITS region, phylogeny. 


\section{INTRODUÇÃO}

Espécies de Pythium e Phytophthora são cosmopolitas, sendo encontradas em uma grande variedade de ambientes. Na maioria dos casos, essas espécies estão associadas a tecidos vegetais infectados ou estão presentes no solo. Representantes do gênero Phytophthora, diferente de Pythium, apresentam pobre capacidade saprofítica, característica que dificulta seu isolamento de tecido necrótico (Erwin \& Ribeiro, 1996; Drenth \& Sendall, 2001). Quando se pretende realizar esse isolamento a partir de amostras de solo ou de água que possuem, na maioria das vezes, uma grande diversidade de microrganismos, o crescimento de fungos saprofíticos e bactérias em meio de cultura pode representar uma limitação. Para Pythium spp., o rápido crescimento em relação aos fungos e a outros oomicetos facilita a separação das colônias, porém para espécies de Phytophthora o desenvolvimento mais lento do micélio pode dificultar seu isolamento. A utilização de antibióticos e fungicidas, que suprimem o crescimento da maioria das bactérias e fungos em meio de cultura, representou um grande avanço no estudo dessas espécies. Além desta técnica, o uso de iscas em amostras de solo ou de água também facilita o isolamento de várias espécies de Pythium e Phytophthora (van Der Plaats Niterink, 1981; Erwin \&Ribeiro, 1996).

Esses dois grandes gêneros, pertencentes à Classe Oomycetes (Index Fungorun, 2014), incluem diversas espécies de fitopatógenos responsáveis por grandes perdas em culturas de interesse econômico. Alguns dos sintomas causados por esses patógenos em plantas são tombamento de mudas, podridão radicular, necrose de tecidos próximos ou em contato com o solo, murcha e redução da biomassa radicular, dificultando a assimilação de nutrientes e água pela planta (Amorim et al., 2011).

Esses sintomas também podem ser decorrentes da ação de outros patógenos ou serem causados por fatores abióticos, como distúrbios hídricos ou nutricionais, dificultando a 
identificação do agente etiológico (Schroeder et al., 2013). Nos últimos anos, A caracterização das espécies de oomicetos baseada em atributos morfológicos, em conjunto com a sintomatologia e gama de hospedeiros, tem contribuído para identificação e taxonomia desses organismos. Vários caracteres são considerados na separação das espécies, principalmente morfologia do oogônio, preenchimento da cavidade oogonial, o tipo de anterídio, entre outros (Waterhouse, 1968, 1970; Stamps et al, 1990). Atenção especial foi dada à morfologia dos esporângios na construção de chaves taxonômicas. A chave proposta por Waterhouse (1963) divide o gênero Phytophthora em seis grupos baseados em três tipos de esporângio (papilados, semi-papilados e não papilados) e dois tipos de anterídio (anfígeno e parágino). De maneira semelhante, van Der Plaats Niterink (1981) separou as espécies de Pythium com base em quatro tipos de esporângio: filamentoso, inflado ou não, e globoso, com ou sem proliferação. Mais tarde, Lévesque \& de Cock (2004) incluíram um quinto tipo: esporângio subgloboso, conectado por segmentos de hifas.

Gallegly \& Hong (2008) separaram as espécies de Phytophthora em homotálicas e heterotálicas, e dentro de cada grupo incluíram o tipo de anterídio, seguido de caracteres morfológicos assexuais como tipo e formato dos esporângios.

No entanto, a plasticidade dos caracteres morfológicos pode dificultar a classificação das espécies, tornando-a ambígua devido às semelhanças entre diferentes espécies e pela influência das condições ambientais na formação das estruturas. Tal problema tem sido contornado com uso de métodos bioquímicos e moleculares (Schroeder et al., 2013).

Dentre as técnicas moleculares que auxiliam a identificação e classificação de Pythium e Phytophthora, a Reação em Cadeia da Polimerase (PCR) tem oferecido maior eficiência, rapidez e precisão na caracterização de microrganismos. Esta técnica permite obter várias cópias de um determinado segmento de DNA. Os fragmentos selecionados são amplificados a partir de iniciadores (primers) que hibridizam na região de interesse. Entre as 
regiões do genoma utilizadas para análises moleculares de Pythium e Phytophthora incluemse os genes que codificam proteínas metabólicas, como citocromo oxidase I (cox I) e citocromo oxidase II (cox II). Estes genes estão envolvidos no transporte de elétrons na cadeia respiratória de organismos eucariotos (Villa et al., 2006). A cox II é um gene encontrado no DNA mitocondrial que acumula mutações, apresentando vantagens na identificação e na filogenia de organismos eucariotos. Outro gene importante é o gene da $\beta$ tubulina que codifica uma das proteínas que constituem os blocos básicos de construção dos microtúbulos. Os microtúbulos são um dos principais componentes do citoesqueleto de células eucarióticas e estão envolvidos em muitos processos essenciais, incluindo a divisão celular, motilidade ciliar e flagelar e transporte intracelular (Mckean et al., 2001; Kammarnjesadakul et al., 2011).

Um dos exemplos de utilização destes genes é o trabalho realizado por Villa et al., (2006). Os autores investigaram as relações filogenéticas de 58 isolados, que correspondiam a 39 espécies de Pythium e 9 de Phytophthora, por meio do sequenciamento de três regiões genômicas, o ITS do rDNA e os genes cox II e $\beta$ tubulina. A análise das três regiões em conjunto revelou que os quatro clados gerados refletiam a morfologia dos esporângios. Utilizando também vários loci presentes no DNA nuclear e mitocondrial, Kroon et al. (2004) realizaram um estudo filogenético utilizando 113 isolados de 48 espécies de Phytophthora. No entanto, os clados gerados não apresentaram consistência com os caracteres morfológicos descritos por Waterhouse (1963).

O grupo de genes que codificam para o RNA ribossômico tem sido utilizado extensivamente para taxonomia e variação genética de Pythium e Phytophthora. Este cluster é composto de três genes (18S, 5.8S e 28S) e duas regiões monogênicas espaçadoras (ITS e IGS) que se repetem centenas de vezes no genoma. A região espaçadora transcrita interna (ITS) revela evolução, permitido diferenciar táxons próximos devido à alta variabilidade 
encontrada em suas sequências nucleotídicas (Hillis \& Dixon, 1991; Fungaro, 2001; Faleiro, 2007). Atualmente existem vários estudos utilizando a região ITS para caracterização e estudo das relações filogenéticas entre espécies de Phytophthora e Pythium (Cooke \& Duncan, 1997; Crawford et al., 1996; Matsumoto et al., 1999; Cooke et al., 2000; Wang et al., 2003; Lévesque \& de Cock, 2004; Scott et al., 2005).

Para a identificação de oomicetos que habitam ecossistemas aquáticos, além da observação das características morfológicas, o sequenciamento da região ITS também tem sido amplamente utilizado. De acordo com Shrestha et al. (2012), o sequenciamento da região ITS permitiu a identificação de 12 espécies de Pythium e Phytophthora encontradas em um levantamento realizado em córregos localizados no Estado de Tennessee, Estados Unidos. Yang \& Hong (2013) descreveram um novo táxon, nomeado como Phytophthora virginiana, descoberto na água de irrigação de viveiros distribuídos no Estado de Virginia (EUA). Para caracterização da espécie foi realizado o sequenciamento da região ITS do rDNA.

Neste capítulo, os isolados de Pyhtium e Phytophthora obtidos em fontes de água de irrigação foram caracterizados a partir da avaliação das estruturas morfológicas e do sequenciamento da região ITS1, ITS2 e 5.8S do rDNA, que subsidiaram a análise filogenética entre as espécies. Por fim, a patogenicidade dos isolados foi testada em frutos de tomate. 


\section{MATERIAL E MÉTODOS}

\subsection{Caracterização molecular}

\subsubsection{Extração de DNA}

Os isolados, obtidos a partir das iscas, foram repicados para meio V8 clarificado. Após o desenvolvimento das colônias, transferiu-se 2 discos ( $5 \mathrm{~mm}$ de diâmetro) contendo micélio para frascos Erlenmeyer contendo $100 \mathrm{~mL}$ de meio líquido BD (Batata + Dextrose). Após quatro dias em agitador automático, o micélio dos isolados que apresentaram crescimento suficiente foi triturado em Ace Homogeneizer (marca Nissei) para auxiliar a lise da célula microbiana no meio líquido. As células foram peletizadas por centrifugação a $13.000 \mathrm{rpm}$ por 5 minutos e o meio líquido descartado. Ao micélio foi adicionado $200 \mu \mathrm{L}$ de

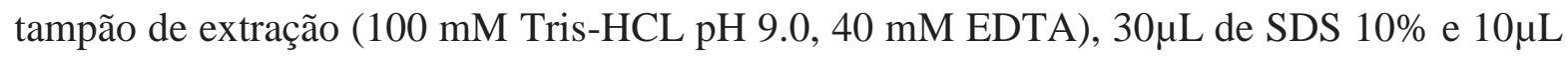
de proteinase $\mathrm{K}$ e agitado vigorosamente em agitador de tubos. Em seguida, a mistura foi incubada a $65^{\circ}$ por 30 minutos e após esse período, adicionou-se $250 \mu \mathrm{L}$ de acetato de amônio $(7,5 \mathrm{M})$, sendo a solução novamente homogeneizada e colocada a $4^{\circ} \mathrm{C}$ por 10 minutos. Posteriormente, foi realizada centrifugação a $13.000 \mathrm{rpm}$ por 20 minutos e o sobrenadante foi transferido para tubos contendo $400 \mu \mathrm{L}$ de isopropanol. As amostras foram incubadas por 1 a 2 horas a $4^{\circ} \mathrm{C}$ e centrifugadas novamente. Por fim, o sobrenadante foi descartado e o precipitado foi lavado cuidadosamente com álcool a 70\%. O DNA foi ressuspendido em $50 \mu \mathrm{L}$ de tampão TE com RNase e armazenado a $-20^{\circ} \mathrm{C}$ (Mahuku, 2004, modificado).

Para utilização na reação de PCR, o DNA foi quantificado em espectrofotômetro NanoDrop $^{\mathrm{TM}}$ (marca Lite) e a qualidade foi checada em gel de agarose (1\%). A concentração final do DNA foi padronizada em 50ng. $\mu 1^{-1}$. 


\subsubsection{Amplificação por PCR da região ITS do rDNA}

A reação de PCR foi realizada utilizando-se os primers universais ITS4 (5', TCCTCCGCTTATTGATATGC 3') e ITS5 (5' GGAAGTAAAAGTCGTAACAAGG 3') que amplificaram as regiões ITS1, ITS2 e 5.8S do DNA ribossômico (White et al., 1990). A PCR foi realizada com o preparo de um Master mix contendo 38,25 $\mu \mathrm{L}$ de água Milli-Q; $5 \mu \mathrm{L}$ de 10x PCR Buffer; $1,5 \mu \mathrm{L}$ de $\mathrm{MgCl}_{2}(50 \mathrm{mM}) ; 1 \mu \mathrm{l}$ de cada primer $(25 \mathrm{mM}) ; 1,0 \mu 1$ de dNTPs $(10 \mathrm{mM}) ; 0,25 \mu \mathrm{l}$ de Taq DNA polimerase $(5 \mathrm{U} / \mu \mathrm{l})$ (Invitrogen) e $2 \mu \mathrm{l}$ de DNA $(50 \mathrm{ng} / \mu \mathrm{l})$ com volume final da reação de $50 \mu 1$ (Caixeta et al., 2013, modificado).

A amplificação do DNA foi realizada em termociclador My Cycler (Bio-Rad Laboratories, Inc.) e ocorreu nas seguintes condições: desnaturação inicial a $94^{\circ} \mathrm{C}$ por cinco minutos; 35 ciclos de desnaturação à $94^{\circ} \mathrm{C}$ por 30 segundos, anelamento a $52{ }^{\circ} \mathrm{C}$ por 45 segundos e extensão a $72^{\circ} \mathrm{C}$ por 2 minutos, e por fim, um ciclo de extensão final a $72^{\circ} \mathrm{C}$ por 7 minutos.

Os produtos da reação de PCR foram visualizados em gel de agarose após eletroforese em tampão TBE (Tris-Ácido Bórico-EDTA) a 0,5\%, realizada a $100 \mathrm{~V}$ por 2 horas. Em seguida o gel foi corado em brometo de etídio e registrado em fotodocumentador L-Pix ST (Loccus Biotecnologia).

O produto da PCR foi purificado utilizando-se o Kit de Purificação PureLink ${ }^{\mathrm{TM}}$ (Invitrogen) e enviado à Macrogen, Inc. (Seul, Coréia do Sul) para sequenciamento. As sequiências de nucleotídeos da região ITS do rDNA de Phytophthora e Pythium foram comparadas utilizando o algoritmo BLASTn disponível on line para confirmar a identidade com base na similaridade com outras sequências depositadas no GenBank e no Banco de Dados de Phytophthora (http://www.Phytophthoradb.org) (Park et al., 2008). 


\subsubsection{Análise Filogenética}

A qualidade das sequências foi observada a partir do programa BioEdit 7.2.5 (Hall, 1999). O alinhamento das sequências e a construção das árvores filogenéticas foram realizados no programa Geneious Pro v.7.1.7 (Biomatters Ltda, Auckland, New Zeland) utilizando o método Neighbor-Joining (Saitou \& Nei, 1987). Os limites de confiança para construção das árvores filogenéticas foram estimados com análise de bootstrap para 10000 repetições.

\subsection{Caracterização morfológica}

Os isolados selecionados foram cultivados em meio de cultura V8 clarificado. Após o desenvolvimento das colônias, discos foram destacados da margem da cultura e foram transferidos para placas de Petri contendo extrato de solo a $10 \%$ e água de córrego autoclavados e não autoclavados (Erwin \& Ribeiro, 1996). As placas foram incubadas em temperatura ambiente de 24 a 72 horas para indução da produção de esporângio. As estruturas assexuais e sexuais foram observadas e fotografadas em microscópio estereoscópio (modelo eclipse E 200, marca Nikon). Para cada isolado, foram escolhidos aleatoriamente de 30 a 50 esporângios e oogônios que foram medidos por meio do programa NIS-Element AR 3.2 (Nikon, Düsseldorf, Germany). O tipo de anterídio, número de anterídios por oogônio, a presença de clamidósporos e espessamento de hifas também foram observados. As características analisadas foram comparadas com as descrições das chaves taxonômicas de Waterhouse (1963, 1970), Stamps et al., (1990) e Gallegly \& Hong (2008) para o gênero Phytophthora e Waterhouse (1968) e van Der Plaats Niterink (1981) para o gênero Pythium. 


\subsection{Teste de patogenicidade em frutos}

Para o teste de patogenicidade, frutos de tomate verdes foram coletados no campo experimental da Embrapa Hortaliças e levados ao laboratório para lavagem e desinfestação. Um isolado representativo de cada espécie de Pythium e Phytophthora obtidos de fontes de água de irrigação foi selecionado. A inoculação foi realizada mediante o contato de um disco de meio de cultura, contendo micélio em crescimento ativo, em ferimento provocado com palito de dente esterilizado no fruto. Foram utilizados quatro frutos para cada isolado, sendo utilizados dois discos que foram colocados em lados opostos de cada fruto de tomate. Em seguida, os frutos foram colocados em câmara úmida a temperatura ambiente. A avaliação foi realizada do segundo ao quarto dia, e consitiu na observação da incidência de podridão de frutos, encontrada por meio da proporção entre o número de frutos com sintomas de podridão e o número total de repetições (quatro) para cada isolado. $\mathrm{O}$ experimento foi repetido duas vezes. 


\section{RESULTADOS E DISCUSSÃO}

\section{Caracterização molecular}

Um total de 157 isolados recuperados das fontes de água entre 2013 e 2014 foram identificados a partir da análise das sequências da região ITS e 5.8S do rDNA. O produto da PCR resultou em uma única banda no gel de agarose que correspondia a fragmentos de 850 a 1000 pares de bases (Figura 13).

O tamanho dos amplicons gerados para os isolados de Phytophthora variou de 821 (Oom102) a 965 pares de bases (pb) (Oom302). Para os isolados de Pythium, os fragmentos gerados possuíam entre $816 \mathrm{pb}(\mathrm{Omm} 010)$ a aproximadamente $1 \mathrm{~Kb}(\mathrm{Omm} 297)$.

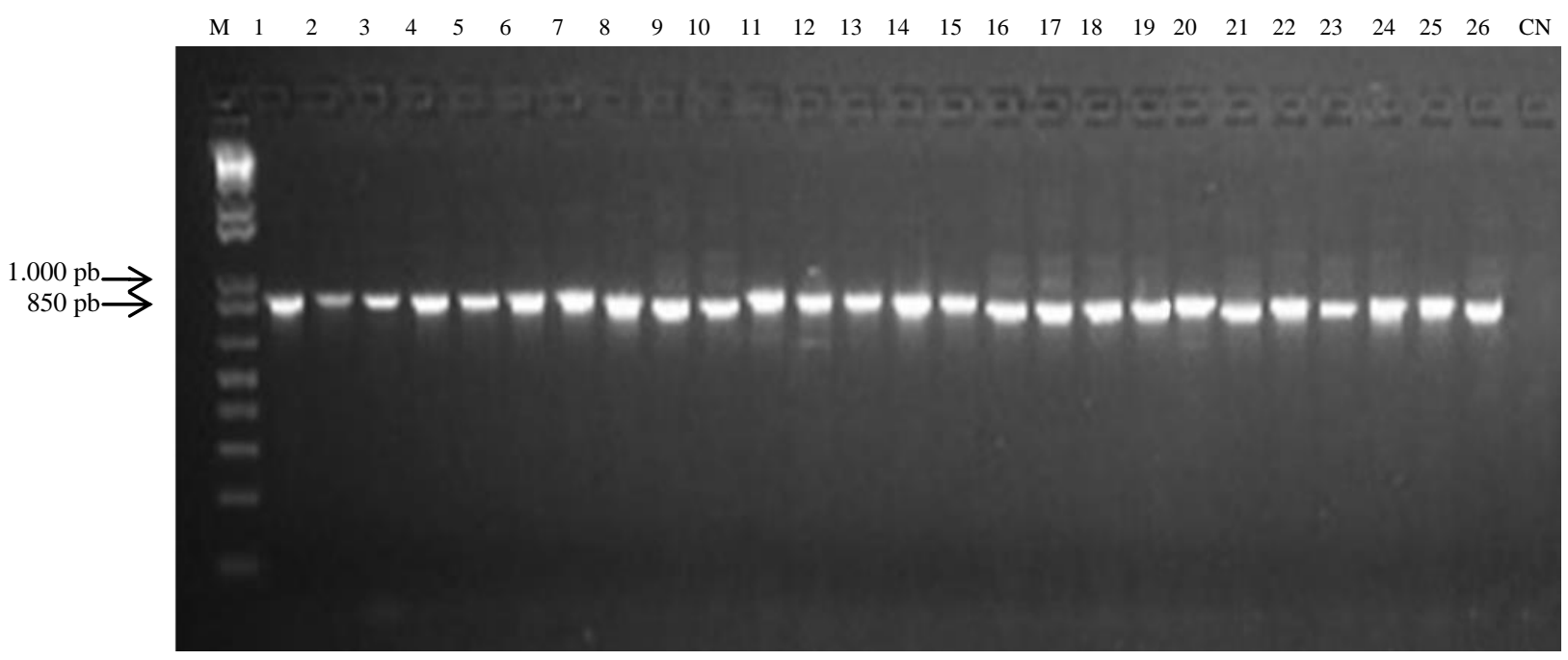

Figura 13. Amplicação da região ITS e 5.8S do rDNA dos isolados de Pythium spp. e Phytophthora spp. utilizando os primers ITS4 e ITS5. M: marcador 1Kb Ladder Plus; 1 a 8: isolados de Pythium sp.; 9 e 10: isolados de Pythium chamaihyphon; 11: Pythium sp.; 12: Pythium catenulatum; 13 e 14: Pythium sp.; 15: Phytophthora sp.; 16 a 20: Pythium helicoides; 21 e 24: Phytophthora sp.; 25: isolado de Pythium graminicola; 26: isolado de Phytophthora sp.; CN: Controle Negativo. 
A comparação das sequências dos isolados com as sequencias depositadas no GenBank revelou uma alta similaridade, demonstrando que 115 isolados pertenciam ao gênero Pythium (Tabela 5), sendo 17 isolados identificados como $P$. helicoides, 13 como $P$. chamaihyphon, 10 como P. catenulatum, 4 como P. myriotylum, 2 como P. graminicola e 69 isolados identificados apenas até o nível de gênero.

Em razão da proposta de reclassificação taxonômica das espécies de Pythium pertencentes ao clado $\mathrm{K}$, as espécies $P$. helicoides e $P$. chamaihyphon, que apresentam esporângios globosos (Lévesque \& de Cock, 2004) deveriam ser nomeadas dentro do gênero Phytopythium por compartilham características morfológicas tanto com Pythium (tubo de descarga dos zoósporos) como com Phytophthora (morfologia do esporângio) (Vila et al., 2008; Bala et al., 2010; Uzuhashi et al., 2010; Marano et al., 2014). No entanto, para facilitar a a interpretação dos dados, os isolados de $P$. helicoides e $P$. chamaihyphon foram colocadas na mesma árvore filogenética dos demais isolados do gênero Pythium obtidos neste estudo.

Tabela 5. Identificação, local e mês de coleta e espécie vegetal utilizada como isca para a detecção dos isolados de Pythium spp. recuperados das fontes de água entre 2013 e 2014.

\begin{tabular}{|c|c|c|c|c|c|c|}
\hline Espécies & $\begin{array}{l}\text { Código dos } \\
\text { isolados }\end{array}$ & Local de coleta & Isca & $\begin{array}{c}\text { Mês/Ano De } \\
\text { Coleta }\end{array}$ & $\begin{array}{l}N^{\circ} \text { de Acesso } \\
\text { do GenBank }\end{array}$ & $\begin{array}{c}\text { Identidade de } \\
\text { pares de base no } \\
\text { banco de dados do } \\
\text { NCBI }(\%) \\
\end{array}$ \\
\hline Pythium helicoides & Oom006 & $\begin{array}{l}\text { Sítio Cachoeira } \\
\text { (nascente) }\end{array}$ & Tomate & Setembro/13 & AB217659 & 99,7 \\
\hline Pythium helicoides & Oom008 & $\begin{array}{c}\text { Sítio Cachoeira } \\
\text { (nascente) }\end{array}$ & Pinos & Outubro/13 & HQ643383 & 98.5 \\
\hline Pythium helicoides & Oom010 & $\begin{array}{l}\text { Sítio Cachoeira } \\
\text { (nascente) }\end{array}$ & Manga & Outubro/13 & AB108034 & 99.6 \\
\hline Pythium helicoides & Oom036 & $\begin{array}{l}\text { Sítio Cachoeira } \\
\text { (reservatório) }\end{array}$ & Tomate & Setembro/13 & HQ643383 & 97.3 \\
\hline Pythium helicoides & Oom071 & $\begin{array}{l}\text { Sítio Cachoeira } \\
\text { (nascente) }\end{array}$ & Palmeira & Novembro/13 & AB108057 & 99.9 \\
\hline Pythium helicoides & Oom072 & $\begin{array}{l}\text { Sítio Cachoeira } \\
\text { (nascente) }\end{array}$ & Pinos & Novembro/13 & AB108057 & 99.9 \\
\hline Pythium helicoides & Oom112 & $\begin{array}{l}\text { Sítio Cachoeira } \\
\text { (nascente) }\end{array}$ & Pinos & Dezembro/13 & AB108057 & 99.9 \\
\hline Pythium helicoides & Oom 157 & $\begin{array}{l}\text { Sítio Cachoeira } \\
\text { (nascente) }\end{array}$ & Citros & Janeiro/14 & AB108057 & 99.7 \\
\hline
\end{tabular}




\begin{tabular}{|c|c|c|c|c|c|c|}
\hline Espécies & $\begin{array}{l}\text { Código dos } \\
\text { isolados }\end{array}$ & Local de coleta & Isca & $\begin{array}{l}\text { Mês/Ano De } \\
\text { Coleta }\end{array}$ & $\begin{array}{r}\mathbf{N}^{\circ} \text { de Acesso } \\
\text { do GenBank }\end{array}$ & $\begin{array}{c}\text { Identidade de } \\
\text { pares de base no } \\
\text { banco de dados do } \\
\text { NCBI }(\%) \\
\end{array}$ \\
\hline Pythium helicoides & Oom124 & $\begin{array}{l}\text { Fazenda Larga Grande } \\
\text { (represa) }\end{array}$ & Pinos & Dezembro/13 & HQ643383 & 99.4 \\
\hline Pythium helicoides & Oom179 & $\begin{array}{l}\text { Sítio Cachoeira } \\
\text { (nascente) }\end{array}$ & Manga & Fevereiro/14 & AY598665 & 99.9 \\
\hline Pythium helicoides & Oom 180 & $\begin{array}{l}\text { Sítio Cachoeira } \\
\text { (nascente) }\end{array}$ & Tomate & Fevereiro/14 & AY598665 & 99.7 \\
\hline Pythium helicoides & Oom183 & $\begin{array}{l}\text { Fazenda Larga Grande } \\
\text { (represa) }\end{array}$ & Citros & Fevereiro/14 & HQ643383 & 99.4 \\
\hline Pythium helicoides & Oom 210 & $\begin{array}{l}\text { Embrapa Hortaliças } \\
\text { (C. Capoeira Grande) }\end{array}$ & Citros & Abril/14 & AY598665 & 91.2 \\
\hline Pythium helicoides & Oom 202 & $\begin{array}{l}\text { Sítio Cachoeira } \\
\text { (nascente) }\end{array}$ & Manga & Março/14 & AY598665 & 99.7 \\
\hline Pythium helicoides & Oom 225 & $\begin{array}{l}\text { Sítio Cachoeira } \\
\text { (reservatório) }\end{array}$ & Citros & Maio/14 & FJ415972 & 94.1 \\
\hline Pythium helicoides & Oom 250 & $\begin{array}{l}\text { Fazenda Larga Grande } \\
\text { (represa) }\end{array}$ & Citros & Junho/14 & HQ643383 & 99.5 \\
\hline Pythium helicoides & Oom 251 & $\begin{array}{l}\text { Fazenda Larga Grande } \\
\text { (represa) }\end{array}$ & Palmeira & Junho/14 & AB108043 & 96.9 \\
\hline $\begin{array}{c}\text { Pythium } \\
\text { chamaihyphon }\end{array}$ & Omm099 & $\begin{array}{l}\text { Embrapa Hortaliças } \\
\text { (C. Capoeira Grande) }\end{array}$ & Manga & Dezembro/13 & FJ415975 & 99.6 \\
\hline $\begin{array}{c}\text { Pythium } \\
\text { chamaihyphon }\end{array}$ & Oom 100 & $\begin{array}{l}\text { Embrapa Hortaliças } \\
\text { (C. Capoeira Grande) }\end{array}$ & Tomate & Dezembro/13 & FJ415975 & 97.9 \\
\hline $\begin{array}{c}\text { Pythium } \\
\text { chamaihyphon }\end{array}$ & Oom 147 & $\begin{array}{l}\text { Embrapa Hortaliças } \\
\text { (C. Capoeira Grande) }\end{array}$ & Pinos & Janeiro/14 & GU266220 & 99.3 \\
\hline $\begin{array}{c}\text { Pythium } \\
\text { chamaihyphon }\end{array}$ & Oom 148 & $\begin{array}{l}\text { Embrapa Hortaliças } \\
\text { (C. Capoeira Grande) }\end{array}$ & Citros & Janeiro/14 & GU266220 & 99.0 \\
\hline $\begin{array}{c}\text { Pythium } \\
\text { chamaihyphon }\end{array}$ & Oom 177 & $\begin{array}{l}\text { Embrapa Hortaliças } \\
\text { (C. Capoeira Grande) }\end{array}$ & Palmeira & Fevereiro/14 & AY598666 & 97.1 \\
\hline $\begin{array}{c}\text { Pythium } \\
\text { chamaihyphon }\end{array}$ & Oom 178 & $\begin{array}{l}\text { Sítio Cachoeira } \\
\text { (reservatório) }\end{array}$ & Palmeira & Fevereiro/14 & HQ643374 & 99.3 \\
\hline $\begin{array}{c}\text { Pythium } \\
\text { chamaihyphon }\end{array}$ & Oom197 & $\begin{array}{l}\text { Embrapa Hortaliças } \\
\text { (C. Capoeira Grande) }\end{array}$ & Capim & Março/14 & AY598666 & 97,5 \\
\hline $\begin{array}{c}\text { Pythium } \\
\text { chamaihyphon }\end{array}$ & Oom199 & $\begin{array}{l}\text { Embrapa Hortaliças } \\
\text { (C. Capoeira Grande) }\end{array}$ & Palmeira & Março/14 & AY598666 & 99 \\
\hline $\begin{array}{c}\text { Pythium } \\
\text { chamaihyphon }\end{array}$ & Oom 221 & $\begin{array}{l}\text { Embrapa Hortaliças } \\
\text { (C. Capoeira Grande) }\end{array}$ & Palmeira & Maio/14 & AY598666 & 98.9 \\
\hline $\begin{array}{c}\text { Pythium } \\
\text { chamaihyphon }\end{array}$ & Oom 222 & $\begin{array}{l}\text { Embrapa Hortaliças } \\
\text { (C. Capoeira Grande) }\end{array}$ & Citros & Maio/14 & AY598666 & 98.0 \\
\hline $\begin{array}{c}\text { Pythium } \\
\text { chamaihyphon }\end{array}$ & Oom 223 & $\begin{array}{l}\text { Embrapa Hortaliças } \\
\text { (C. Capoeira Grande) }\end{array}$ & Tomate & Maio/14 & HQ643374 & 98.9 \\
\hline $\begin{array}{c}\text { Pythium } \\
\text { chamaihyphon }\end{array}$ & Oom 247 & $\begin{array}{l}\text { Embrapa Hortaliças } \\
\text { (C. Capoeira Grande) }\end{array}$ & Manga & Junho/14 & HQ643374 & 98.6 \\
\hline $\begin{array}{c}\text { Pythium } \\
\text { chamaihyphon }\end{array}$ & Oom 271 & $\begin{array}{l}\text { Embrapa Hortaliças } \\
\text { (C. Capoeira Grande) }\end{array}$ & Capim & Julho/14 & AY598666 & 98.9 \\
\hline Pythium myriotylum & Oom044 & $\begin{array}{l}\text { Sítio Cachoeira } \\
\text { (nascente) }\end{array}$ & Capim & Outubro/13 & KJ162354 & 99.5 \\
\hline
\end{tabular}




\begin{tabular}{|c|c|c|c|c|c|c|}
\hline Espécies & $\begin{array}{l}\text { Código dos } \\
\text { isolados }\end{array}$ & Local de coleta & Isca & $\begin{array}{l}\text { Mês/Ano De } \\
\text { Coleta }\end{array}$ & $\begin{array}{r}\mathbf{N}^{\circ} \text { de Acesso } \\
\text { do GenBank }\end{array}$ & $\begin{array}{c}\text { Identidade de } \\
\text { pares de base no } \\
\text { banco de dados do } \\
\text { NCBI }(\%) \\
\end{array}$ \\
\hline Pythium myriotylum & Oom058 & $\begin{array}{l}\text { Sítio Cachoeira } \\
\text { (nascente) }\end{array}$ & Palmeira & Outubro/13 & HQ237488 & 100.0 \\
\hline Pythium myriotylum & Oom070 & $\begin{array}{l}\text { Sítio Cachoeira } \\
\text { (reservatório) }\end{array}$ & Tomate & Novembro/13 & HQ237488 & 99.6 \\
\hline Pythium myriotylum & Oom 278 & $\begin{array}{l}\text { Sítio Cachoeira } \\
\text { (nascente) }\end{array}$ & Capim & Julho/14 & HQ237488 & 99.9 \\
\hline $\begin{array}{l}\text { Pythium } \\
\text { graminicola }\end{array}$ & Oom 166 & $\begin{array}{l}\text { Sítio Cachoeira } \\
\text { (nascente) }\end{array}$ & Capim & Janeiro/14 & HQ877863 & 96.6 \\
\hline $\begin{array}{c}\text { Pythium } \\
\text { graminicola }\end{array}$ & Oom201 & $\begin{array}{l}\text { Sítio Cachoeira } \\
\text { (nascente) }\end{array}$ & Capim & Março/14 & AY598625 & 99.8 \\
\hline $\begin{array}{c}\text { Pythium } \\
\text { catenulatum }\end{array}$ & Oom013 & $\begin{array}{l}\text { Embrapa Hortaliças } \\
\text { (tanque) }\end{array}$ & Tomate & Setembro/13 & HQ237487 & 99.0 \\
\hline $\begin{array}{c}\text { Pythium } \\
\text { catenulatum }\end{array}$ & Oom055 & $\begin{array}{l}\text { Embrapa Hortaliças } \\
\text { (tanque) }\end{array}$ & Tomate & Outubro/13 & HQ237487 & 99.5 \\
\hline $\begin{array}{l}\text { Pythium } \\
\text { catenulatum }\end{array}$ & Oom089 & $\begin{array}{l}\text { Embrapa Hortaliças } \\
\text { (tanque) }\end{array}$ & Capim & Dezembro/13 & GU233294 & 99.8 \\
\hline $\begin{array}{l}\text { Pythium } \\
\text { catenulatum }\end{array}$ & Oom090 & $\begin{array}{l}\text { Embrapa Hortaliças } \\
\text { (tanque) }\end{array}$ & Citros & Dezembro/13 & AY598675 & 99.5 \\
\hline $\begin{array}{l}\text { Pythium } \\
\text { catenulatum }\end{array}$ & Oom092 & $\begin{array}{l}\text { Embrapa Hortaliças } \\
\text { (tanque) }\end{array}$ & Palmeira & Dezembro/13 & GU233294 & 99.6 \\
\hline $\begin{array}{c}\text { Pythium } \\
\text { catenulatum }\end{array}$ & Oom109 & $\begin{array}{l}\text { Embrapa Hortaliças } \\
\text { (tanque) }\end{array}$ & Tomate & Dezembro/13 & GU233294 & 99.6 \\
\hline $\begin{array}{l}\text { Pythium } \\
\text { catenulatum }\end{array}$ & Oom168 & $\begin{array}{l}\text { Embrapa Hortaliças } \\
\text { (tanque) }\end{array}$ & Capim & Fevereiro/14 & GU233294 & 99.8 \\
\hline $\begin{array}{l}\text { Pythium } \\
\text { catenulatum }\end{array}$ & Oom169 & $\begin{array}{l}\text { Embrapa Hortaliças } \\
\text { (tanque) }\end{array}$ & Citros & Fevereiro/14 & GU233294 & 99.6 \\
\hline $\begin{array}{l}\text { Pythium } \\
\text { catenulatum }\end{array}$ & Oom 176 & $\begin{array}{l}\text { Embrapa Hortaliças } \\
\text { (tanque) }\end{array}$ & Manga & Fevereiro/14 & GU233294 & 99.8 \\
\hline $\begin{array}{c}\text { Pythium } \\
\text { catenulatum }\end{array}$ & Oom 184 & $\begin{array}{l}\text { Embrapa Hortaliças } \\
\text { (tanque) }\end{array}$ & Citros & Fevereiro/14 & GU233294 & 99.6 \\
\hline Pythium sp. & Oom022 & $\begin{array}{l}\text { Embrapa Hortaliças } \\
\text { (C. Capoeira Grande) }\end{array}$ & Capim & Setembro/13 & GU259496 & 99.4 \\
\hline Pythium sp. & Oom026 & $\begin{array}{l}\text { Sítio Cachoeira } \\
\text { (reservatório) }\end{array}$ & Capim & Setembro/13 & HQ261734 & 100.0 \\
\hline Pythium sp. & Oom035 & $\begin{array}{c}\text { RECOR } \\
\text { (Córrego do Roncador) }\end{array}$ & Citros & Setembro/13 & GU594783 & 99.6 \\
\hline Pythium sp. & Oom039 & $\begin{array}{l}\text { Embrapa Hortaliças } \\
\text { (C. Capoeira Grande) }\end{array}$ & Capim & Outubro/13 & HQ643814 & 99.5 \\
\hline Pythium sp. & Oom040 & $\begin{array}{l}\text { Embrapa Hortaliças } \\
\text { (C. Capoeira Grande) }\end{array}$ & Capim & Outubro/13 & GU259496 & 99.9 \\
\hline Pythium sp. & Oom045 & $\begin{array}{c}\text { RECOR } \\
\text { (Córrego do Roncador) }\end{array}$ & Capim & Outubro/13 & GU594783 & 99.6 \\
\hline Pythium sp. & Oom046 & $\begin{array}{c}\text { RECOR } \\
\text { (Córrego do Roncador) }\end{array}$ & Citros & Outubro/13 & GU594783 & 99.6 \\
\hline Pythium sp. & Oom047 & $\begin{array}{c}\text { RECOR } \\
\text { (Córrego do Roncador) }\end{array}$ & Palmeira & Outubro/13 & GU594783 & 99.6 \\
\hline
\end{tabular}




\begin{tabular}{|c|c|c|c|c|c|c|}
\hline Espécies & $\begin{array}{l}\text { Código dos } \\
\text { isolados }\end{array}$ & Local de coleta & Isca & $\begin{array}{l}\text { Mês/Ano De } \\
\text { Coleta }\end{array}$ & $\begin{array}{r}\mathbf{N}^{\circ} \text { de Acesso } \\
\text { do GenBank }\end{array}$ & $\begin{array}{c}\text { Identidade de } \\
\text { pares de base no } \\
\text { banco de dados do } \\
\text { NCBI }(\%) \\
\end{array}$ \\
\hline Pythium sp. & Oom048 & $\begin{array}{c}\text { RECOR } \\
\text { (Córrego do Roncador) }\end{array}$ & Manga & Outubro/13 & GU594783 & 99.4 \\
\hline Pythium sp. & Oom049 & $\begin{array}{c}\text { RECOR } \\
\text { (Córrego do Roncador) }\end{array}$ & Tomate & Outubro/13 & GU594783 & 99.7 \\
\hline Pythium sp. & Oom056 & $\begin{array}{l}\text { Sítio Cachoeira } \\
\text { (reservatório) }\end{array}$ & Tomate & Outubro/13 & GQ980050 & 97.7 \\
\hline Pythium sp. & Oom065 & $\begin{array}{l}\text { Embrapa Hortaliças } \\
\text { (C. Capoeira Grande) }\end{array}$ & Tomate & Novembro/13 & HQ643814 & 99.6 \\
\hline Pythium sp. & Oom074 & $\begin{array}{l}\text { Fazenda Larga Grande } \\
\text { (represa) }\end{array}$ & Capim & Novembro/13 & GQ980050 & 97.3 \\
\hline Pythium sp. & Oom084 & $\begin{array}{l}\text { Fazenda Larga Grande } \\
\text { (represa) }\end{array}$ & Capim & Novembro/13 & GQ980050 & 96.6 \\
\hline Pythium sp. & Oom101 & $\begin{array}{l}\text { Sítio Cachoeira } \\
\text { (reservatório) }\end{array}$ & Capim & Dezembro/13 & EU544193 & 99.3 \\
\hline Pythium sp. & Oom105 & $\begin{array}{l}\text { Embrapa Hortaliças } \\
\text { (C. Capoeira Grande) }\end{array}$ & Capim & Dezembro/13 & EU544193 & 99.8 \\
\hline Pythium sp. & Oom 120 & $\begin{array}{l}\text { Fazenda Larga Grande } \\
\text { (córrego) }\end{array}$ & Capim & Dezembro/13 & GU594783 & 99.7 \\
\hline Pythium sp. & Oom134 & $\begin{array}{c}\text { RECOR } \\
\text { (Córrego do Roncador) }\end{array}$ & Manga & Dezembro/13 & GU594783 & 99.6 \\
\hline Pythium sp. & Oom135 & $\begin{array}{c}\text { RECOR } \\
\text { (Córrego do Roncador) }\end{array}$ & Manga & Dezembro/13 & HQ261736 & 99.4 \\
\hline Pythium sp. & Oom137 & $\begin{array}{c}\text { RECOR } \\
\text { (Córrego do Roncador) }\end{array}$ & Capim & Janeiro/14 & GU594783 & 99.6 \\
\hline Pythium sp. & Oom138 & $\begin{array}{c}\text { RECOR } \\
\text { (Córrego do Roncador) }\end{array}$ & Capim & Janeiro/14 & GU594783 & 99.7 \\
\hline Pythium sp. & Oom139 & $\begin{array}{c}\text { RECOR } \\
\text { (Córrego do Roncador) }\end{array}$ & Citros & Janeiro/14 & GU594783 & 99.6 \\
\hline Pythium sp. & Oom 140 & $\begin{array}{c}\text { RECOR } \\
\text { (Córrego do Roncador) }\end{array}$ & Palmeira & Janeiro/14 & GU594783 & 99.5 \\
\hline Pythium sp. & Oom141 & $\begin{array}{c}\text { RECOR } \\
\text { (Córrego do Roncador) }\end{array}$ & Manga & Janeiro/14 & GU258620 & 99.4 \\
\hline Pythium sp. & Oom 142 & $\begin{array}{c}\text { RECOR } \\
\text { (Córrego do Roncador) }\end{array}$ & Manga & Janeiro/14 & GU594783 & 99.3 \\
\hline Pythium sp. & Oom143 & $\begin{array}{c}\text { RECOR } \\
\text { (Córrego do Roncador) }\end{array}$ & Tomate & Janeiro/14 & HQ261736 & 99.0 \\
\hline Pythium sp. & Oom144 & $\begin{array}{l}\text { Fazenda Larga Grande } \\
\text { (córrego) }\end{array}$ & Capim & Janeiro/14 & GQ980050 & 97.0 \\
\hline Pythium sp. & Oom 146 & $\begin{array}{l}\text { Fazenda Larga Grande } \\
\text { (córrego) }\end{array}$ & Manga & Janeiro/14 & GU594783 & 99.7 \\
\hline Pythium sp. & Oom149 & $\begin{array}{l}\text { Embrapa Hortaliças } \\
\text { (C. Capoeira Grande) }\end{array}$ & Tomate & Janeiro/14 & EU544193 & 99.6 \\
\hline Pythium sp & Oom151 & $\begin{array}{l}\text { Sítio Cachoeira } \\
\text { (reservatório) }\end{array}$ & Capim & Janeiro/14 & GQ980050 & 97.5 \\
\hline Pythium sp & Oom152 & $\begin{array}{l}\text { Sítio Cachoeira } \\
\text { (reservatório) }\end{array}$ & Palmeira & Janeiro/14 & GQ980050 & 97.8 \\
\hline
\end{tabular}




\begin{tabular}{|c|c|c|c|c|c|c|}
\hline Espécies & $\begin{array}{l}\text { Código dos } \\
\text { isolados }\end{array}$ & Local de coleta & Isca & $\begin{array}{l}\text { Mês/Ano De } \\
\text { Coleta }\end{array}$ & $\begin{array}{r}N^{\circ} \text { de Acesso } \\
\text { do GenBank }\end{array}$ & $\begin{array}{c}\text { Identidade de } \\
\text { pares de base no } \\
\text { banco de dados do } \\
\text { NCBI }(\%) \\
\end{array}$ \\
\hline Pythium sp. & Oom 153 & $\begin{array}{l}\text { Sítio Cachoeira } \\
\text { (reservatório) }\end{array}$ & Tomate & Janeiro/14 & HQ261734 & 100.0 \\
\hline Pythium sp. & Oom 154 & $\begin{array}{l}\text { Sítio Cachoeira } \\
\text { (reservatório) }\end{array}$ & Tomate & Janeiro/14 & HQ261734 & 100.0 \\
\hline Pythium sp. & Oom 159 & $\begin{array}{l}\text { Fazenda Larga Grande } \\
\text { (represa) }\end{array}$ & Pinos & Janeiro/14 & GQ980050 & 97.3 \\
\hline Pythium sp. & Oom161 & $\begin{array}{l}\text { Fazenda Larga Grande } \\
\text { (represa) }\end{array}$ & Citros & Janeiro/14 & GQ980050 & 97.3 \\
\hline Pythium sp. & Oom 172 & $\begin{array}{l}\text { Embrapa Hortaliças } \\
\text { (C. Capoeira Grande) }\end{array}$ & Manga & Fevereiro/14 & EU544193 & 99.6 \\
\hline Pythium sp. & Oom173 & $\begin{array}{l}\text { Fazenda Larga Grande } \\
\text { (córrego) }\end{array}$ & Citros & Fevereiro/14 & GU594783 & 99.7 \\
\hline Pythium sp. & Oom 174 & $\begin{array}{l}\text { Fazenda Larga Grande } \\
\text { (córrego) }\end{array}$ & Palmeira & Fevereiro/14 & GU594783 & 100.0 \\
\hline Pythium sp. & Oom181 & $\begin{array}{l}\text { Fazenda Larga Grande } \\
\text { (represa) }\end{array}$ & Capim & Fevereiro/14 & GQ980050 & 97.3 \\
\hline Pythium sp. & Oom192 & $\begin{array}{c}\text { RECOR } \\
\text { (Córrego do Roncador) }\end{array}$ & Citros & Fevereiro/14 & GU594783 & 99.7 \\
\hline Pythium sp. & Oom193 & $\begin{array}{c}\text { RECOR } \\
\text { (Córrego do Roncador) }\end{array}$ & Palmeira & Fevereiro/14 & GU594783 & 99.7 \\
\hline Pythium sp. & Oom195 & $\begin{array}{l}\text { Fazenda Larga Grande } \\
\text { (córrego) }\end{array}$ & Citros & Fevereiro/14 & GU594783 & 99.7 \\
\hline Pythium sp. & Oom196 & $\begin{array}{c}\text { Embrapa Hortaliças } \\
\text { (tanque) }\end{array}$ & Tomate & Março/14 & EU136622 & 98.1 \\
\hline Pythium sp. & Oom 203 & $\begin{array}{l}\text { Sítio Cachoeira } \\
\text { (nascente) }\end{array}$ & Tomate & Março/14 & GQ980050 & 92,4 \\
\hline Pythium sp. & Oom 214 & $\begin{array}{l}\text { Sítio Cachoeira } \\
\text { (nascente) }\end{array}$ & Citros & Abril/14 & HQ261734 & 100.0 \\
\hline Pythium sp. & Oom 215 & $\begin{array}{l}\text { Sítio Cachoeira } \\
\text { (nascente) }\end{array}$ & Manga & Abril/14 & HQ261734 & 100.0 \\
\hline Pythium sp. & Oom 216 & $\begin{array}{c}\text { RECOR } \\
\text { (Córrego do Roncador) }\end{array}$ & Capim & Abril/14 & HQ643814 & 96.3 \\
\hline Pythium sp. & Oom231 & $\begin{array}{c}\text { RECOR } \\
\text { (Córrego do Roncador) }\end{array}$ & Capim & Maio/14 & HQ261736 & 99.0 \\
\hline Pythium sp. & Oom 232 & $\begin{array}{c}\text { RECOR } \\
\text { (Córrego do Roncador) }\end{array}$ & Citros & Maio/14 & GU594783 & 99.7 \\
\hline Pythium sp. & Oom 233 & $\begin{array}{c}\text { RECOR } \\
\text { (Córrego do Roncador) }\end{array}$ & Palmeira & Maio/14 & HQ261736 & 99.1 \\
\hline Pythium sp. & Oom234 & $\begin{array}{c}\text { RECOR } \\
\text { (Córrego do Roncador) }\end{array}$ & Palmeira & Maio/14 & GU594783 & 99.9 \\
\hline Pythium sp. & Oom 237 & $\begin{array}{l}\text { Fazenda Larga Grande } \\
\text { (córrego) }\end{array}$ & Capim & Março/14 & GU594783 & 99.7 \\
\hline Pythium sp. & Oom 242 & $\begin{array}{l}\text { Fazenda Larga Grande } \\
\text { (córrego) }\end{array}$ & Capim & Maio/14 & GU594783 & 99.7 \\
\hline Pythium sp. & Oom249 & $\begin{array}{c}\text { Fazenda Larga Grande } \\
\text { (córrego) }\end{array}$ & Citros & Junho/14 & GU594783 & 99.7 \\
\hline
\end{tabular}




\begin{tabular}{|c|c|c|c|c|c|c|}
\hline Espécies & $\begin{array}{l}\text { Código dos } \\
\text { isolados }\end{array}$ & Local de coleta & Isca & $\begin{array}{l}\text { Mês/Ano De } \\
\text { Coleta }\end{array}$ & $\begin{array}{r}\mathbf{N}^{\circ} \text { de Acesso } \\
\text { do GenBank }\end{array}$ & $\begin{array}{c}\text { Identidade de } \\
\text { pares de base no } \\
\text { banco de dados do } \\
\text { NCBI }(\%) \\
\end{array}$ \\
\hline Pythium sp. & Oom 252 & $\begin{array}{c}\text { Embrapa Hortaliças } \\
\text { (tanque) }\end{array}$ & Palmeira & Junho/14 & EU136622 & 99.2 \\
\hline Pythium sp. & Oom 259 & $\begin{array}{l}\text { Fazenda Larga Grande } \\
\text { (córrego) }\end{array}$ & Manga & Junho/14 & HQ261736 & 99.9 \\
\hline Pythium sp. & Oom 262 & $\begin{array}{c}\text { RECOR } \\
\text { (Córrego do Roncador) }\end{array}$ & Capim & Junho/14 & GU594783 & 99.9 \\
\hline Pythium sp. & Oom 263 & $\begin{array}{l}\text { Fazenda Larga Grande } \\
\text { (córrego) }\end{array}$ & Capim & Fevereiro/14 & GU594783 & 100.0 \\
\hline Pythium sp. & Oom 266 & $\begin{array}{c}\text { Embrapa Hortaliças } \\
\text { (tanque) }\end{array}$ & Manga & Abril/14 & EU544193 & 99.9 \\
\hline Pythium sp. & Oom 268 & $\begin{array}{l}\text { Fazenda Larga Grande } \\
\text { (córrego) }\end{array}$ & Tomate & Abril/14 & GU594783 & 99.9 \\
\hline Pythium sp. & Oom 269 & $\begin{array}{c}\text { Embrapa Hortaliças } \\
\text { (tanque) }\end{array}$ & Citros & Julho/14 & EU544193 & 98,6 \\
\hline Pythium sp. & Oom 270 & $\begin{array}{c}\text { Embrapa Hortaliças } \\
\text { (tanque) }\end{array}$ & Palmeira & Julho/14 & HQ261734 & 100.0 \\
\hline Pythium sp & Oom 284 & $\begin{array}{c}\text { Embrapa Hortaliças } \\
\text { (tanque) }\end{array}$ & Tomate & Agosto/14 & EU544193 & 100.0 \\
\hline Pythium sp & Oom 285 & $\begin{array}{c}\text { Embrapa Hortaliças } \\
\text { (tanque) }\end{array}$ & Citros & Agosto/14 & EU095416 & 99.8 \\
\hline Pythium sp. & Oom 288 & $\begin{array}{l}\text { Sítio Cachoeira } \\
\text { (nascente) }\end{array}$ & Tomate & Agosto/14 & GU594783 & 99.1 \\
\hline Pythium sp. & Oom 289 & $\begin{array}{c}\text { Embrapa Hortaliças } \\
\text { (tanque) }\end{array}$ & Capim & Agosto/14 & EU544193 & 99.9 \\
\hline Pythium sp. & Oom 297 & $\begin{array}{c}\text { RECOR } \\
\text { (Córrego do Roncador) }\end{array}$ & Citros & Agosto/14 & GU594783 & 98.9 \\
\hline Pythium sp. & Oom 298 & $\begin{array}{c}\text { RECOR } \\
\text { (Córrego do Roncador) }\end{array}$ & Palmeira & Agosto/14 & GU594783 & 100.0 \\
\hline Pythium sp. & Oom304 & $\begin{array}{c}\text { Fazenda Larga Grande } \\
\text { (represa) }\end{array}$ & Tomate & Agosto/14 & HQ261732 & 99.2 \\
\hline
\end{tabular}

Quarenta e três isolados apresentaram maior identidade da sequência nucleotídica com espécies pertencentes ao gênero Phytophthora (Tabela 6), resultando em 2 isolados de $P$. quininea e 2 isolados de $P$. macrochlamydospora. Trinta e nove isolados não foram identificados a nível subgenérico. 
Tabela 6. Identificação, local e mês de coleta e espécie vegetal utilizada como isca para a detecção dos isolados de Phythophthora spp. recuperados das fontes de água entre 2013 e 2014.

\begin{tabular}{|c|c|c|c|c|c|c|}
\hline Espécies & $\begin{array}{c}\text { Código } \\
\text { dos } \\
\text { isolados }\end{array}$ & Local de coleta & Isca & $\begin{array}{l}\text { Mês/Ano de } \\
\text { Coleta }\end{array}$ & $\begin{array}{c}\text { No Acesso em } \\
\text { Phytophthoradb.org }\end{array}$ & $\begin{array}{c}\text { Identidade de } \\
\text { pares de bases } \\
(\%)\end{array}$ \\
\hline Phytophthora quininea & Oom067 & $\begin{array}{c}\text { RECOR } \\
\text { (Córrego do Roncador) }\end{array}$ & Pinos & Outubro/13 & PD02107 & 99,62 \\
\hline Phytophthora quininea & Oom217 & $\begin{array}{l}\text { Fazenda Larga Grande } \\
\text { (córrego) }\end{array}$ & Manga & Abril/14 & PD02107 & 99,87 \\
\hline $\begin{array}{c}\text { Phytophthora } \\
\text { macrochlamydospora }\end{array}$ & Oom205 & $\begin{array}{c}\text { RECOR } \\
\text { (Córrego do Roncador) }\end{array}$ & Palmeira & Março/14 & PD00006 & 95,73 \\
\hline $\begin{array}{c}\text { Phytophthora } \\
\text { macrochlamydospora }\end{array}$ & Oom 258 & $\begin{array}{c}\text { RECOR } \\
\text { (Córrego do Roncador) }\end{array}$ & Palmeira & Junho/14 & PD01248 & 99,87 \\
\hline Phytophthora sp. & Oom052 & $\begin{array}{l}\text { Embrapa Hortaliças } \\
\text { (C. Capoeira Grande) }\end{array}$ & Pinos & Outubro/13 & PD01851 & 99,06 \\
\hline Phytophthora sp. & Oom053 & $\begin{array}{l}\text { Sítio Cachoeira } \\
\text { (reservatório) }\end{array}$ & Pinos & Outubro/13 & PD01851 & 98,65 \\
\hline Phytophthora sp. & Oom057 & $\begin{array}{l}\text { Sítio Cachoeira } \\
\text { (nascente) }\end{array}$ & Palmeira & Outubro/13 & PD01851 & 98,39 \\
\hline Phytophthora sp. & Oom078 & $\begin{array}{l}\text { Sítio Cachoeira } \\
\text { (nascente) }\end{array}$ & Pinos & Novembro/13 & PD01851 & 98,79 \\
\hline Phytophthora sp. & Oom079 & $\begin{array}{l}\text { Sítio Cachoeira } \\
\text { (nascente) }\end{array}$ & Citros & Novembro/13 & PD01851 & 98,92 \\
\hline Phytophthora sp. & Oom081 & $\begin{array}{l}\text { Sítio Cachoeira } \\
\text { (nascente) }\end{array}$ & Manga & Novembro/13 & PD01851 & 99.19 \\
\hline Phytophthora sp. & Oom093 & $\begin{array}{l}\text { Embrapa Hortaliças } \\
\text { (C. Capoeira Grande) }\end{array}$ & Pinos & Dezembro/13 & PD01851 & 98,46 \\
\hline Phytophthora sp. & Oom098 & $\begin{array}{l}\text { Embrapa Hortaliças } \\
\text { (C. Capoeira Grande) }\end{array}$ & Manga & Dezembro/13 & PD01851 & 99,04 \\
\hline Phytophthora sp. & Oom102 & $\begin{array}{l}\text { Sítio Cachoeira } \\
\text { (reservatório) }\end{array}$ & Pinos & Dezembro/13 & PD01851 & 98,79 \\
\hline Phytophthora sp. & Oom103 & $\begin{array}{l}\text { Sítio Cachoeira } \\
\text { (reservatório) }\end{array}$ & Palmeira & Dezembro/13 & PD01851 & 98,73 \\
\hline Phytophthora sp. & Oom107 & $\begin{array}{l}\text { Embrapa Hortaliças } \\
\text { (C. Capoeira Grande) }\end{array}$ & Capim & Dezembro/13 & PD01851 & 98,11 \\
\hline Phytophthora sp. & Oom113 & $\begin{array}{l}\text { Sítio Cachoeira } \\
\text { (nascente) }\end{array}$ & Capim & Dezembro/13 & PD01851 & 99,06 \\
\hline Phytophthora sp. & Oom125 & $\begin{array}{l}\text { Fazenda Larga Grande } \\
\text { (represa) }\end{array}$ & Citros & Dezembro/13 & PD01851 & 98,65 \\
\hline Phytophthora sp. & Oom155 & $\begin{array}{l}\text { Sítio Cachoeira } \\
\text { (nascente) }\end{array}$ & Pinos & Janeiro/14 & PD01851 & 99,06 \\
\hline Phytophthora sp. & Oom156 & $\begin{array}{l}\text { Sítio Cachoeira } \\
\text { (nascente) }\end{array}$ & Citros & Janeiro/14 & PD01851 & 98,92 \\
\hline Phytophthora sp. & Oom164 & $\begin{array}{l}\text { Sítio Cachoeira } \\
\text { (reservatório) }\end{array}$ & Citros & Janeiro/14 & PD01851 & 98,65 \\
\hline Phytophthora sp. & Oom167 & $\begin{array}{l}\text { Sítio Cachoeira } \\
\text { (nascente) }\end{array}$ & Palmeira & Janeiro/14 & PD01851 & 98,92 \\
\hline
\end{tabular}




\begin{tabular}{|c|c|c|c|c|c|c|}
\hline Espécies & $\begin{array}{c}\text { Código } \\
\text { dos } \\
\text { isolados } \\
\end{array}$ & Local de coleta & Isca & $\begin{array}{l}\text { Mês/Ano de } \\
\text { Coleta }\end{array}$ & $\begin{array}{c}\text { No Acesso em } \\
\text { Phytophthoradb.org }\end{array}$ & $\begin{array}{c}\text { Identidade de } \\
\text { pares de bases } \\
(\%)\end{array}$ \\
\hline Phytophthora sp. & Oom171 & $\begin{array}{l}\text { Embrapa Hortaliças } \\
\text { (C. Capoeira Grande) }\end{array}$ & Manga & Fevereiro/14 & PD01851 & 99,05 \\
\hline Phytophthora sp. & Oom 186 & $\begin{array}{l}\text { Embrapa Hortaliças } \\
\text { (C. Capoeira Grande) }\end{array}$ & Tomate & Fevereiro/14 & PD01851 & 97,85 \\
\hline Phytophthora sp. & Oom189 & $\begin{array}{l}\text { Sítio Cachoeira } \\
\text { (reservatório) }\end{array}$ & Tomate & Fevereiro/14 & PD01851 & 98,65 \\
\hline Phytophthora sp. & Oom198 & $\begin{array}{l}\text { Embrapa Hortaliças } \\
\text { (C. Capoeira Grande) }\end{array}$ & Manga & Março/14 & PD01851 & 98,92 \\
\hline Phytophthora sp. & Oom204 & $\begin{array}{l}\text { Sítio Cachoeira } \\
\text { (nascente) }\end{array}$ & Palmeira & Março/14 & PD01851 & 98,92 \\
\hline Phytophthora sp. & Oom206 & $\begin{array}{l}\text { Fazenda Larga Grande } \\
\text { (represa) }\end{array}$ & Capim & Março/14 & PD01851 & 98,79 \\
\hline Phytophthora sp. & Oom 207 & $\begin{array}{l}\text { Embrapa Hortaliças } \\
\text { (C. Capoeira Grande) }\end{array}$ & Citros & Março/14 & PD01851 & 98,65 \\
\hline Phytophthora sp. & Oom 220 & $\begin{array}{l}\text { Embrapa Hortaliças } \\
\text { (C. Capoeira Grande) }\end{array}$ & Palmeira & Maio/14 & PD01851 & 98,38 \\
\hline Phytophthora sp. & Oom 227 & $\begin{array}{l}\text { Sítio Cachoeira } \\
\text { (nascente) }\end{array}$ & Capim & Maio/14 & PD01851 & 98,57 \\
\hline Phytophthora sp. & Oom 238 & $\begin{array}{l}\text { Fazenda Larga Grande } \\
\text { (represa) }\end{array}$ & Palmeira & Março/14 & PD01853 & 95,87 \\
\hline Phytophthora sp. & Oom 245 & $\begin{array}{l}\text { Fazenda Larga Grande } \\
\text { (represa) }\end{array}$ & Capim & Maio/14 & PD01851 & 99,05 \\
\hline Phytophthora sp. & Oom 246 & $\begin{array}{l}\text { Fazenda Larga Grande } \\
\text { (represa) }\end{array}$ & Manga & Maio/14 & PD01851 & 98,92 \\
\hline Phytophthora sp. & Oom 253 & $\begin{array}{c}\text { Embrapa Hortaliças } \\
\text { (tanque) }\end{array}$ & Manga & Junho/14 & PD01851 & 98,53 \\
\hline Phytophthora sp. & Oom 254 & $\begin{array}{c}\text { Embrapa Hortaliças } \\
\text { (tanque) }\end{array}$ & Tomate & Junho/14 & PD01851 & 98,25 \\
\hline Phytophthora sp. & Oom 256 & $\begin{array}{l}\text { Sítio Cachoeira } \\
\text { (reservatório) }\end{array}$ & Manga & Junho/14 & PD01851 & 99,06 \\
\hline Phytophthora sp. & Oom 260 & $\begin{array}{l}\text { Embrapa Hortaliças } \\
\text { (C. Capoeira Grande) }\end{array}$ & Citros & Junho/14 & PD01851 & 98,61 \\
\hline Phytophthora sp. & Oom 261 & $\begin{array}{l}\text { Sítio Cachoeira } \\
\text { (nascente) }\end{array}$ & Palmeira & Junho/14 & PD01851 & 98 \\
\hline Phytophthora sp. & Oom 292 & $\begin{array}{l}\text { Embrapa Hortaliças } \\
\text { (C. Capoeira Grande) }\end{array}$ & Tomate & Agosto/14 & PD01851 & 98,01 \\
\hline Phytophthora sp. & Oom294 & $\begin{array}{l}\text { Sítio Cachoeira } \\
\text { (reservatório) }\end{array}$ & Palmeira & Agosto/14 & PD01851 & 97,77 \\
\hline Phytophthora sp. & Oom302 & $\begin{array}{l}\text { Fazenda Larga Grande } \\
\text { (represa) }\end{array}$ & Palmeira & Agosto/14 & PD01853 & 95,18 \\
\hline Phytophthora sp. & Oom303 & $\begin{array}{c}\text { Fazenda Larga Grande } \\
\text { (represa) }\end{array}$ & Manga & Agosto/14 & PD01853 & 95,68 \\
\hline
\end{tabular}


Todas as espécies de Pythium encontradas neste estudo já foram relatadas anteriormente em fontes de água em outros locais (Gill, 1970; Shrestha et al., 2013).

A espécie $P$. myriotylum foi detectada somente nos meses de Outubro, Novembro e Julho, enquanto $P$. graminicola foi encontrada nos meses de Janeiro e Março, ambas no Sítio Cachoeira. Da mesma forma, Phytophthora quininea foi encontrada no córrego do Roncador e no córrego localizado na Fazenda Larga Grande, nos meses de Outubro/2013 e Abril/2014, respectivamente. A espécie Phytophthora macrochlamydospora foi encontrada somente no córrego do Roncador nos meses de Março e Junho de 2014.

As espécies de Pythium encontradas com maior frequência neste estudo foram $P$. helicoides e $P$. chamaihyphon, que representaram aproximadamente $13 \%$ e $11 \%$ do total de isolados de Pythium caracterizados, respectivamente.

\section{Análise Filogenética}

As árvores filogenéticas são apresentadas nas Figuras 14 e 15. Houve uma maior distância genética entre os isolados pertencentes ao gênero Pythium que entre os isolados de Phytophthora, evidenciando a origem polifilética desse gênero (Briard et al., 1995; Uzuhashi et al., 2010). Diferente do que foi observado na árvore filogenética de Phytophthora, diversos isolados da mesma espécie de Pythium foram recuperados no mesmo local de amostragem, porém essa mesma relação não foi observada para o tipo de isca utilizada.

As espécies de Pythium encontradas neste trabalho foram agrupadas com espécies pertencentes aos clados B e K (Lévesque \& De Cock, 2004) de acordo com a morfologia dos esporângios. Assim, os isolados identificados como P. helicoides (Oom006, Oom008, Oom010, Oom036, Oom071, Oom072, Oom112, Oom124, Oom157, Oom179, Oom180, Oom183, Oom202, Oom210, Oom225, Oom250 e Oom251) e como P. chamaihyphon (Oom099, Oom100, Oom147, Oom148, Oom177, Oom197, Oom199, Oom221, Oom222, 
Oom223, Oom247 e Oom271) permaneceram agrupados no clado K, que engloba espécies com esporângios globosos a subglobosos, com suporte de bootstrap de 99,95\%. Os isolados classificados como P. catenulatum (Oom013, Oom055, Oom089, Oom090, Oom092, Oom109, Oom168, Oom169, Oom176, Oom184), P. myriotylum (Oom044, Oom058, Oom070 e Oom278) e P. graminicola (Oom166 e Oom201), que apresentam esporângios filamentosos, foram incluídas no mesmo clado, com suporte de bootstrap que variou de 50,79 a $100 \%$ nos subclados. Da mesma forma, o trabalho realizado por Matsumoto et al. (1999) dividiu o gênero em dois grupos, o primeiro reunindo espécies que apresentam esporângios esféricos ("grupo S") e o segundo, as espécies com esporângios filamentosos ("grupo F”). A importância da morfologia do esporângio na definição da relação evolutiva entre as espécies também foi comprovada por Villa et al. (2006).

Os isolados Oom022, Oom039, Oom 040, Oom065, Oom 101, Oom105, Oom149, Oom 153, Oom 154, Oom 172, Oom 214, Oom215, Oom266 e Oom270 não agruparam com nehuma espécie descrita de Pythium, formando um subclado com o isolado de referência Pythium sp. (EU544193), com valores de bootstrap moderados (entre 54,09\% a 76\%). Da mesma forma, os isolados Oom035, Oom045, Oom046, Oom047, Oom048, Oom049, Oom120, Oom146, Oom173, Oom174, Oom192, Oom193, Oom195, Oom231, Oom232, Oom233, Oom234, Oom237, Oom242, Oom262, Oom263 e Oom268 agruparam com outro táxon desconhecido de Pythium sp. (GU594783) (Figura 14).

Os isolados identificados como P. catenulatum (Oom013, Oom055, Oom089, Oom090, Oom092, Oom109, Oom168, Oom169, Oom176, Oom184) devido à maior similaridade da sequência nucleotídica da região ITS com essa espécie, formaram um dos sub-clados menos conclusivos dentro do gênero devido à alta similaridade obtida também com as espécies P. pyrilobum (JQ898473), P. rhizo-orizae (AY207379) e P. torulosum (JQ898476). Igualmente, os isolados Oom196 e Oom252 formaram um subclado com as 
espécies $P$. porphyrae (AB043506) e P. chondricola (HQ643498), parasitas de algas marinhas (Takahashi et al., 1977), com suporte de bootstrap de 100\%. Segundo Robideau et al. (2011) não existe variação suficiente nas sequências da região ITS entre algumas espécies de Pythium e Phytophthora que permitam a identificação de determinados isolados, sendo necessário a avaliação das características morfológicas ou o sequenciamento de outros genes em alguns casos. No caso de $P$. catenulatum, a classificação dos isolados foi suportada por meio da caracterização morfológica (Tabela 7), em que foi observada a formação de espessamento de hifas em cadeia, característica encontrada apenas em $P$. catenulatum segundo van Der Plaats Niterink (1981). Da mesma forma, os isolados Oom201 e Oom166 foram identificados como $P$. graminicola devido ao tamanho dos oogônios e oósporos que foram maiores do que os descritos para P. periilum (Waterhouse, 1968). Para os isolados Oom196 e Oom252, a dificuldade observada na formação de estruturas assexuais e sexuais fez com que esses isolados não fossem identificados a nível de espécie. 


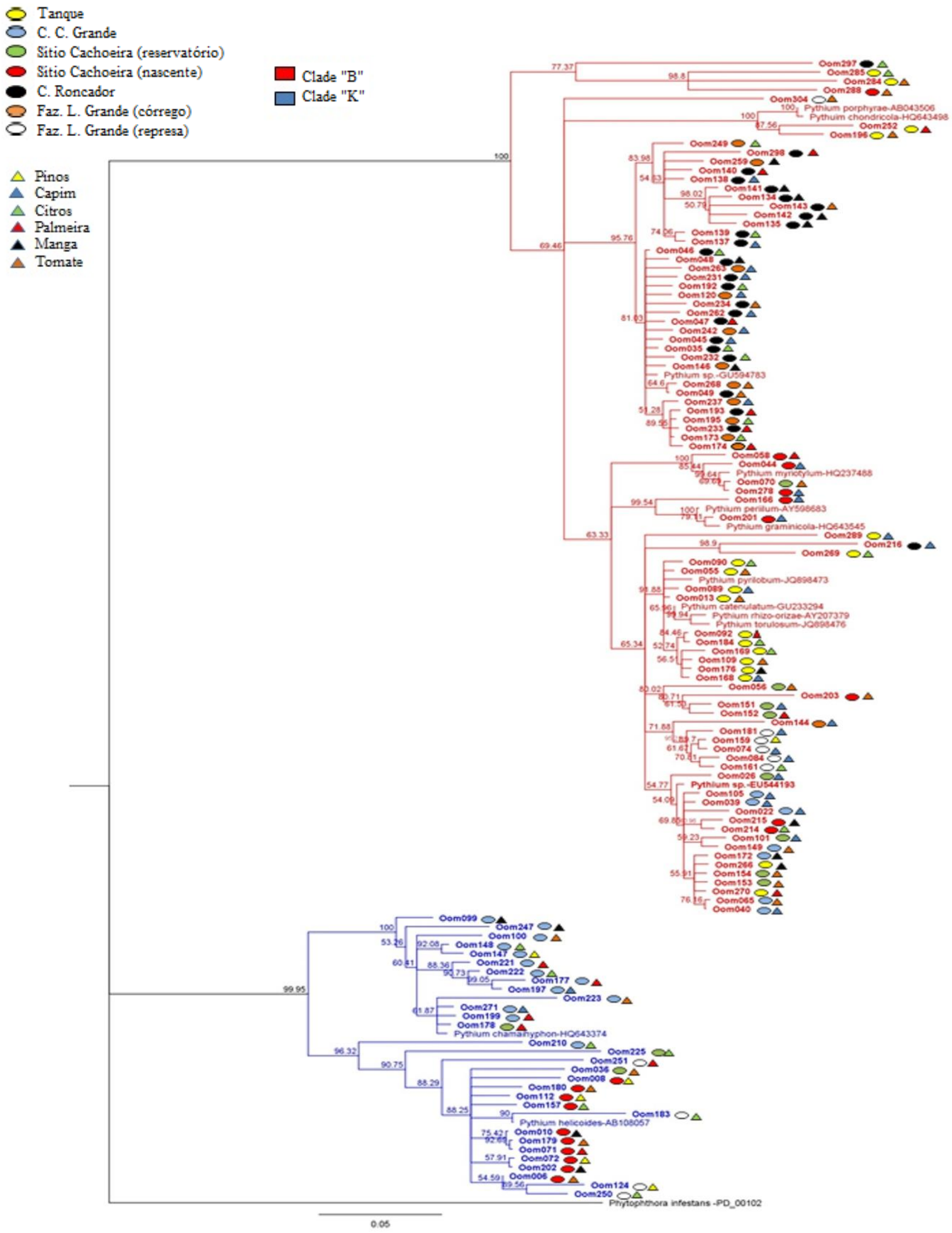

Figura 14. Árvore filogenética, construída com sequências dos isolados de Pythium spp., baseada na análise da região ITS1, 5.8S e ITS2 do rDNA obtida pelo método Neighborjoining. O número nas ramificações representa o valor de "bootstrap". O isolado de Phytophthora infestans foi utilizado como grupo externo. Classificação dos clados de acordo Com Lévesque \& de Cock (2004), sendo o clado em cor vermelha definido como "Clado B" e o clado em cor azul definido como "Clado K". 
Todas as espécies de Phytophthora encontradas neste estudo foram agrupadas dentro do clado 9 de acordo com a classificação realizada por Blair et al. (2008), com valores de bootstrap entre 50,15 a 100\% (Figura 15). Uma a duas sequências de espécies de referências que pertencem aos clados 1 a 8 foram utilizadas para ilustrar a distância dos isolados obtidos com as demais espécies de Phytophthora. O clado 9 foi adicionado por meio da análise de vários locus gênicos (Blair et al., 2008) aos oito clados observados por Cooke et al. (2000) a partir da análise das sequências da região ITS do rDNA. A separação dos clados 1 a 8 é praticamente a mesma nos dois trabalhos. O clado 9 inclui espécies descritas incialmente em água de irrigação como $P$. hydropathica, $P$. irrigata e $P$. virginiana (Hong et al., 2008; Hong et al., 2010; Yang et al., 2014)

Os isolados Oom067 e Oom217 identificados como P. quininea (PD_02107) (Tabela 6) agruparam com essa espécie em um subclado com suporte de bootstrap de $86,81 \%$ (Figura 15). Os isolados Oom 205 e Oom 258 formaram um subclado com $P$. richardiae (PD_ 00119) e P. macrochlamydospora ( $\mathrm{PD}_{-}$00006) com bootstrap de 72,11\%. P. richardiae e $P$. macrochlamydospora possuem a sequência de pares de bases da região ITS quase idênticas, justificando o agrupamento dessas duas espécies no mesmo sub-clado. No entanto, a espécie P. richardiae não forma clamidósporos de acordo com Erwin \& Ribeiro (1996), estrutura que foi observada no isolado Oom205, confirmando a identidade do isolado como $P$. macrochlamydospora.

Os subclados formados com os isolados em que apenas o gênero foi identificado foram menos conclusivos. Como exemplo, os isolados Oom292, Oom294, Oom302 e Oom303 não agruparam com nenhuma espécie de Phytophthora conhecida, assim como o subclado formado com os isolados Oom 057, Oom079, Oom081, Oom 093, Oom102, Oom125, Oom164, Oom167, Oom186, Oom187, Oom189, Oom204, Oom206, Oom207, Oom 220, Oom245, Oom246, Oom254 e Oom256 que agruparam próximos às espécies $P$. sp. 
lagoariana (PD_01299), P. hydropathica (PD_00495) e à um táxon não identificado, Phytophthora sp. (PD_01851) (Figura 15).

Yang et al. (2014) concluíram que espécies encontradas nos mesmos subclados ou clados são mais adaptadas a ecossistemas específicos. Brasier (1983) também observou a separação de dois grupos segundo o habitat ocupado pelas espécies, sendo um composto por espécies com dispersão aérea, como $P$. palmivora e $P$. infestans, e o segundo formado por patógenos de solo, como Phytophthora cinnamomi e P. cambivora. Cooke et al. (2000) também observaram a mesma separação de Brasier (1983), com as espécies que possuem dispersão aérea pertencendo aos clados 1 a 5, enquanto as espécies que são habitantes de solo estão incluídos nos clados de 6 e 8, havendo exceções dentro dos dois grupos. Da mesma forma, espécies pertencentes ao clado $6 \mathrm{~b}$ e as espécies do clado 9 são associadas a ambientes aquáticos, como reservatórios de água de irrigação, rios e córregos (Brasier et al., 2003; Hong et al., 2008; Jung et al., 2011; Yang \& Hong, 2013). Esse agrupamento das espécies segundo o modo de dispersão não foi considerado por Blair et al. (2008) devido à grande quantidade de exceções, observando que espécies com modos de dispersão distintos são encontradas no mesmo clado.

Segundo Cooke et al. (2000), esporângios papilados e não papilados nunca são encontrados no mesmo clado e as espécies com esporângios semi-papilados estão incluídas em ambos os grupos. Apesar desses autores não encontrarem associação da separação dos clados com os grupos morfológicos descritos por Waterhouse (1963) assim como em outros estudos (Crawford et al., 1996; Foster et al., 2000; Martin \& Tooley, 2003), Blair et al. (2008) notaram que existe uma sobreposição de diversas características morfológicas dentro dos clados. Dessa forma, o clado 9, que compreendeu todas os isolados encontrados neste trabalho, é representado por espécies dos grupos V e VI, que possuem esporângios semipapilados ou não papilados. 
Os isolados pertencentes à subclados formados sem isolados de referência, ou seja, apenas com os isolados obtidos durante as coletas, assim como aqueles em que não foi possível uma identificação a nível de espécie, foram preservados para uma melhor investigação a respeito de sua identidade por meio do sequenciamento de outras regiões genômicas e o emprego de outras metodologias para indução da formação de estrutras morfológicas, e observação de características fisiológicas e culturais. 

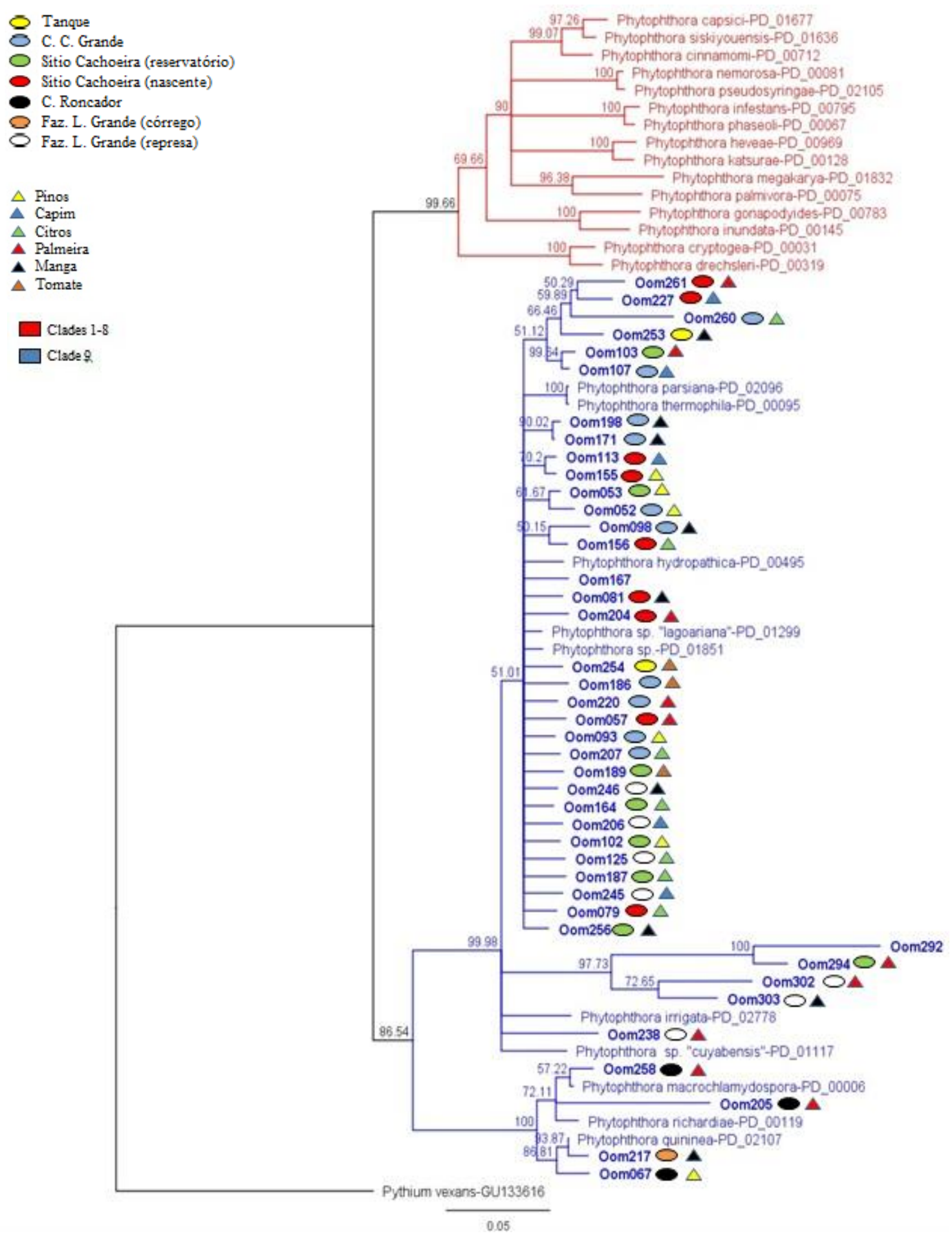

Figura 15. Árvore filogenética, construída com sequências dos isolados de Phytophthora spp., baseada na análise da região ITS1, 5.8S e ITS2 do rDNA obtida pelo método Neighborjoining. O número nas ramificações representa o valor de "bootstrap". O isolado de Pythium vexans foi utilizado como grupo externo. Classificação dos clados de acordo com Blair et al. (2008), sendo o clado em cor vermelha formado por espécies classificadas dentro dos clados de 1-8 e todos os isolados obtidos nesse estudo agrupados no clado em cor azul, junto com espécies classificadas dentro do clado 9. 
A dificuldade observada na indução da formação das estruturas sexuais e assexuais dos isolados e a semelhança dos caracteres morfológicos entre espécies diferentes confirmam a praticidade do uso de técnicas moleculares na identificação e caracterização de Pythium e Phytophthora. No entanto, alguns isolados foram classificados apenas até o nível de gênero por meio do sequenciamento da região ITS. Em muitos casos, isso foi consequência da alta similaridade das sequências da região ITS com espécies muito próximas. Além disso, a interpretação da árvore filogenética baseada apenas nas sequências da região ITS pode gerar informações equivocadas já que em muitos casos os ramos dos clados apresentaram suporte de bootstrap fraco, como já foi observado por Cooke et al. (2000). Outro fator é a redução da qualidade do alinhamento de múltiplas sequências desta região quando a distância evolutiva entre os isolados avaliados é grande (Feliner \& Rossello, 2007). Desta forma, tornou-se evidente a necessidade de utilização de outros genes na caracterização das espécies, principalmente para a compreensão da relação evolutiva entre os isolados encontrados (Villa et al., 2006; Blair et al, 2008). 


\section{Caracterização morfológica}

Após o sequenciamento da região ITS de 157 isolados, um isolado representativo de cada espécie encontrada em fontes de água foi selecionado para a caracterização morfológica. O tamanho das estruturas observadas é apresentado na Tabela 7. A morfologia de cada característica avaliada segue abaixo (Figuras 16 e 17).

Tabela 7. Características morfológicas dos isolados encontrados em fontes de água entre 2013 e 2014.

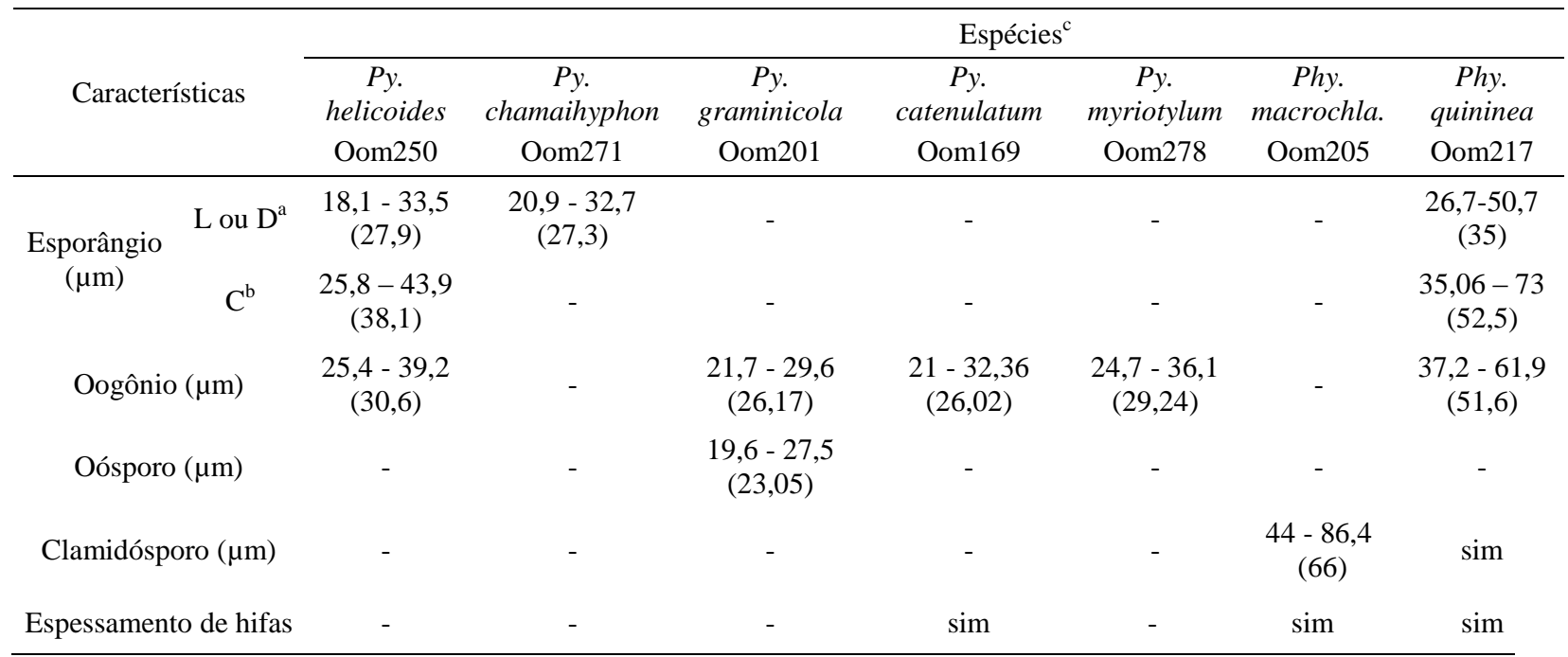

Amplitude da variação das medidas de cada estrutura seguida da média entre parênteses.

${ }_{b}^{\mathrm{a}} \mathrm{L}$ e $\mathrm{D}=$ Largura e diâmetro dos esporângios

${ }^{\mathrm{C}} \mathrm{C}=$ Comprimento dos esporângios

c Oom250: Pythium helicoides; Oom271: Pythium chamaihyphon; Oom201: Pythium graminicola; Oom169: Pythium catenulatum;

Oom278: Pythium myriotylum; Oom217: Phytophthora quininea; Oom205: Phytophthora macrochlamydospora.

- : estrutura não observada. "sim": estruturas encontradas.

\section{Pythium helicoides Drechesler}

A espécie foi capaz de produzir oogônios abundantemente em extrato de solo autoclavado. Os oogônios são terminais, laterais ou intercalados, globosos, apresentando parede lisa. Os anterídios são díclinos e alongados, em alguns casos foram encontrados mais de um anterídio por oogônio (Figura 16. A e B). Os esporângios são terminais com proliferação, subglobosos e pseudo-papilados (Figura 16. C e D). 


\section{Pythium chamaihyphon Sideris}

Esporângio subgloboso a oblongo (Figura 16. E), com diâmetro mínimo dentro do limite inferior proposto por van Der Plaats Niterink (1981), porém divergindo no limite superior que ficou mais próximo da descrição realizada por Waterhouse (1968). As estruturas sexuais não foram observadas.

\section{Pythium catenulatum Matthews}

Esporângios filamentosos, consistindo de partes do micélio dilatadas (Figura 16. H). Espessamento de hifas em cadeias de 3-8, 10-20 mm de diâmetro (Figura 16. G). Oogônio terminal e intercalar, às vezes produzidos em culturas individuais, esférica, com parede lisa (Figura 16. F). Oósporos principalmente plerótico, em alguns casos aplerótico.

Pythium graminicola Subramaniam

Os esporângios são filamentosos, podendo ser terminais ou intercalados (Figura 16. L). Oogônios são terminais e intercalados, possuindo paredes lisas e formato globoso (Figura 16. J e K). Oósporo plerótico (Figura 16. I), com variação de diâmetro similar a observada por van Der Plats Niterink (1981). O anterídio geralmente é monóclino.

\section{Pythium myriotylum Drechsler}

Esporângios filamentosos, consistindo de elementos inflados com formato digitado ou lobulado (Figura 16. O e P). Oogônios globosos a subglobosos, terminais ou intercalados, com medidas dentro da amplitude considerada pela chave de van Der Plats Niterink (1981), apresentando mais de um anterídio em cada oogônio (Figura 16. M e N). 


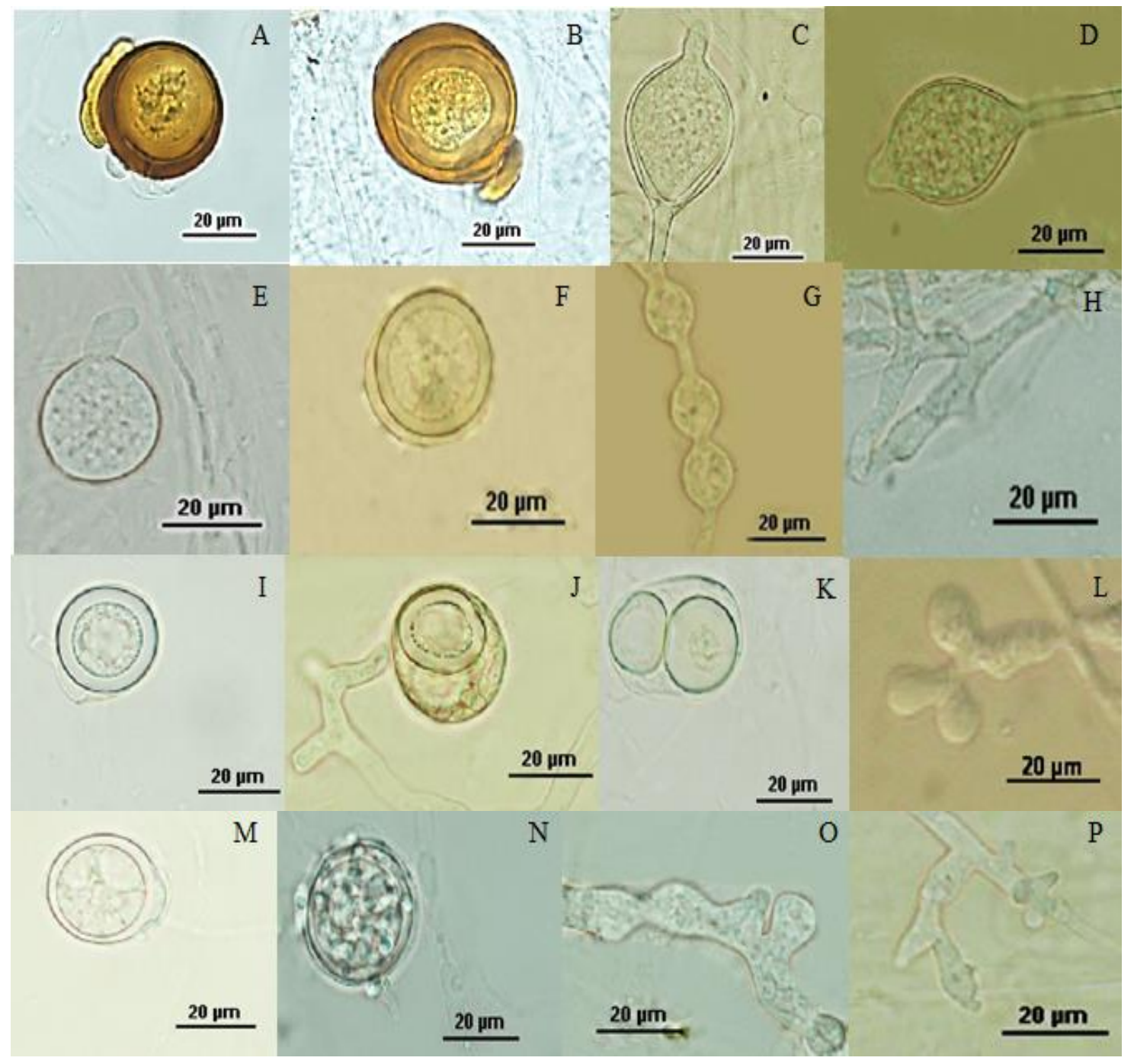

Figura 16. Estruturas morfológicas de Pythium spp. Oogônio com anterídio (A) (B) e esporângios papilados (C) (D) de P. helicoides; esporângios (E) de P. chamaihyphon; oogônio (F), espessamento de hifas em cadeia $(\mathrm{G})$ e esporângios filamentos $(\mathrm{H})$ de P. catenulatum; oósporo (I), oogônios (J) (K) e esporângios filamentosos (L) de P. graminicola; oogônios (M) (N) e esporângios (O) (P) de P. myriotylum. 


\section{Phytophthora sp.}

Espécies de Phytophthora não identidficada a nível de espécie, porém foi possível a observação de esporângios (Figura 17. A, B e C).

\section{Phytophthora macrochlamydospora Irwin}

Segundo a classificação taxonômica de Stamps et al. (1990), a espécie é classificada no grupo III ou IV devido à produção de esporângios semipapilados. A espécie produz clamidósporos grandes e esféricos que são terminais ou intercalados (Figura 17. D e E). A presença de espessamentos de hifas esféricos a elipsóides também foi observada (Figura 17. F).

Phytophthora quininea Crand

Classificada no grupo $\mathrm{V}$, produzindo esporângios ovalados a obpiriformes, mais amplos na base, e não papilados (Figura17. G e J) (Waterhouse,1963, 1970; Stamps, 1990). O anterídio é parágino e os oogônios são subesféricos a esféricos (Figura 17. K e L). A espécie forma ainda clamidósporos e espessamento de hifas (Figura 17. M e N). 


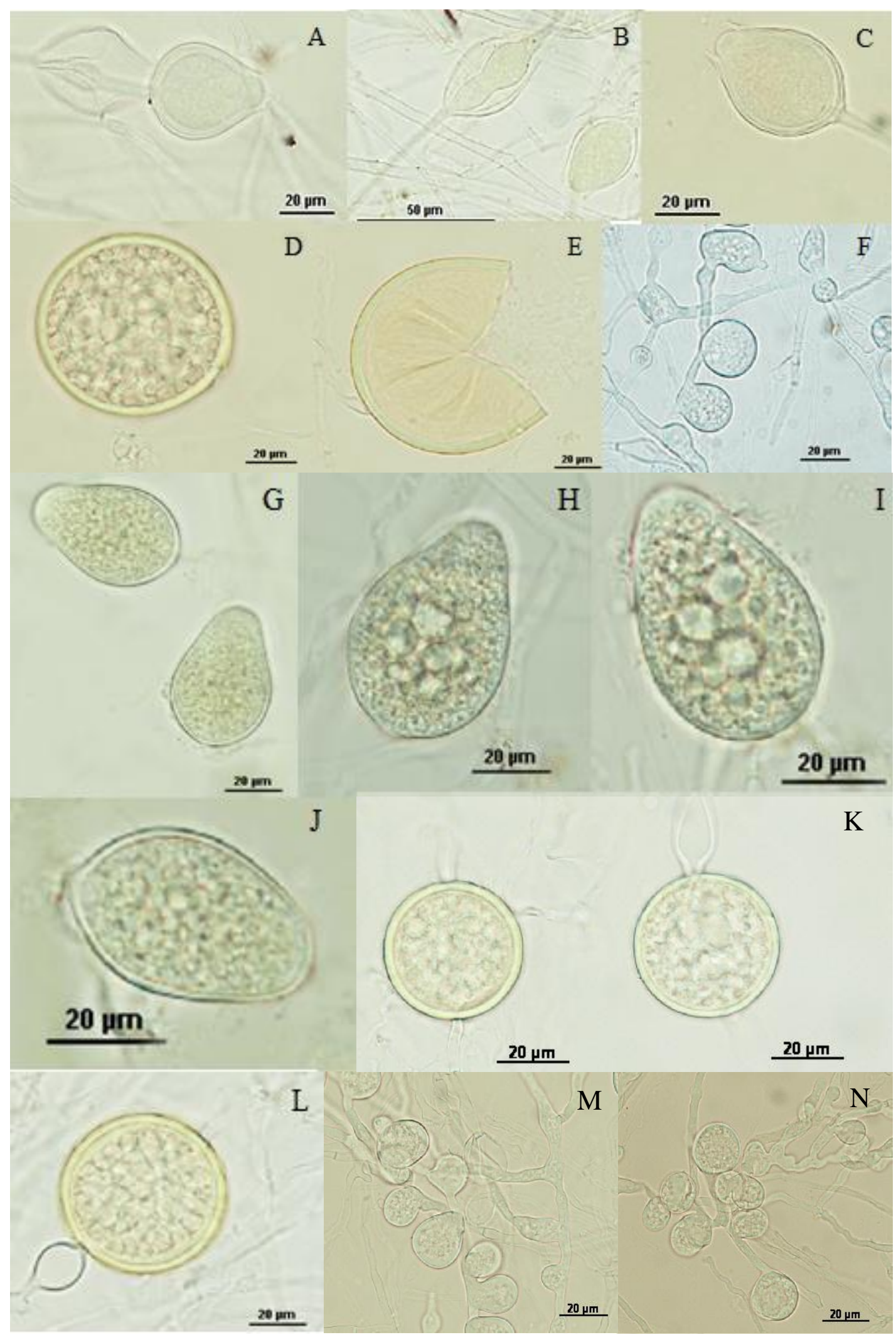

Figura 17. Estrutras morfológicas de Phytophthora spp. Esporângios de Phytophthora sp. (A) (B) (C); clamidósporos (D) (E) e espessamento de hifas (F) de P. macrochlamydospora; Esporângios não papilados $(\mathrm{G})(\mathrm{H})(\mathrm{I})(\mathrm{J})$, oogônios $(\mathrm{K})(\mathrm{L})$ e espessamento de hifas $(\mathrm{M})(\mathrm{N})$ de $P$. quininea. 


\section{Teste de patogenicidade em frutos}

Sintomas de podridão de frutos não foram observados para todos os isolados testados (Tabela 8). O isolado de $P$. helicoides (Oom250) foi constantemente patogênico, sendo que 100\% das repetições inoculadas com esse isolado apresentaram sintomas no segundo dia após a inoculação (DAI). Esse isolado foi também o mais agressivo, causando podridão em todo o diâmetro do fruto ao terceiro dia após a inoculação. De maneira semelhante, o isolado de $P$. chamaihyphon (Oom271) causou podridão de frutos em 100\% das repetições na primeira vez em que o experimento foi conduzido, porém em uma das repetições a podridão de frutos só foi observada após o $3^{\circ}$ DAI. Já no segundo experimento, 75\% das repetições apresentaram sintoma durante os dias de avaliação.

O isolado que representa a espécie $P$. myriotylum, causou sintoma em $25 \%$ dos frutos após o $3^{\circ} \mathrm{DAI}$ no primeiro experimento, enquanto no segundo experimento, a incidência foi de 25,75 e $100 \%$, no $2^{\circ}, 3^{\circ}$ e $4^{\circ}$ DAI, respectivamente. Os isolados Oom 135 e Oom 285 não causaram podridão de frutos durante a segunda repetição do experimento. Ao contrário, os isolados Oom289 e Oom304 não causaram sintomas no primeiro experimento, mas na segunda tentativa, $25 \%$ das repetição para cada isolado apresentaram sintomas no $3^{\circ}$ DAI. $P$. graminicola (Oom201) causou podridão apenas em uma das repetições (25\%) nos dois experimentos.

Em nenhum dos experimentos foi observado sintoma de podridão de frutos causado pelo isolado Oom303, que corresponde a uma espécie não identificada de Phytophthora. O isolado Oom 227 causou podridão de frutos em apenas $25 \%$ dos frutos no $4^{\circ}$ DAI no segundo experimento, enquanto o isolado Oom 256 causou sintomas em $50 \%$ dos frutos no primeiro experimento e em 75\%, segundo experimento. O isolado de Phytophthora quininea (Oom217) causou podridão em $25 \%$ dos frutos nos dois experimentos. Já para o isolado de 
P. macrochlamydospora (Oom205), 50\% das repetições apresentaram sintomas de podridão em cada experimento.

Tabela 8. Incidência da doença (\%) em frutos de tomate observada em 2, 3 e 4 dias após a inoculação (DAI) em dois experimentos.

\begin{tabular}{|c|c|c|c|c|c|c|c|}
\hline \multicolumn{5}{|c|}{ Experimento 1} & \multicolumn{3}{|c|}{ Experimento 2} \\
\hline \multirow{2}{*}{ Isolados } & \multicolumn{3}{|c|}{ DAI } & \multirow{2}{*}{ Isolados } & \multicolumn{3}{|c|}{ DAI } \\
\hline & 2 & 3 & 4 & & 2 & 3 & 4 \\
\hline Oom250 & 100 & 100 & 100 & Oom250 & 100 & 100 & 100 \\
\hline Oom304 & 0 & 0 & 0 & Oom304 & 0 & 25 & 25 \\
\hline Oom289 & 0 & 0 & 0 & Oom289 & 0 & 25 & 25 \\
\hline Oom201 & 25 & 25 & 25 & Oom201 & 0 & 0 & 25 \\
\hline Oom135 & 0 & 0 & 50 & Oom135 & 0 & 0 & 0 \\
\hline Oom285 & 25 & 50 & 100 & Oom285 & 0 & 0 & 0 \\
\hline Oom278 & 0 & 25 & 25 & Oom278 & 25 & 75 & 100 \\
\hline Oom271 & 75 & 100 & 100 & Oom271 & 25 & 75 & 75 \\
\hline Oom113 & 0 & 0 & 50 & Oom113 & 0 & 25 & 75 \\
\hline Oom205 & 25 & 25 & 50 & Oom205 & 50 & 50 & 50 \\
\hline Oom217 & 25 & 25 & 25 & Oom217 & 0 & 0 & 25 \\
\hline Oom256 & 0 & 25 & 50 & Oom256 & 25 & 75 & 75 \\
\hline Oom227 & 0 & 0 & 0 & Oom227 & 0 & 0 & 25 \\
\hline Oom303 & 0 & 0 & 0 & Oom303 & 0 & 0 & 0 \\
\hline
\end{tabular}

\section{Patogenicidade das espécies encontradas}

Pythium helicoides foi inicialmente isolado em Dahlia em 1930. Posteriormente foi descrita como agente causal de podridão radicular e tombamento de mudas em diversas espécies vegetais, como melancia (Citrullus vulgaris L.), cana-de-açúcar (Saccharum officinarum L.), ervilha (Pisum sativum L.), soja (Glycine max), pimenta do reino (Piper 
nigrum L.), Hibiscus sp., morangueiro (Fragaria x ananassa Duch.), entre outras (Middleton, 1943; Liu, 1977; van Der Plaats-Niterink, 1981; Watanabe et al., 2005).

. Em estudos de patogenicidade em plantas de tomateiro, P. helicoides foi capaz de causar podridão radicular e reduzir o peso das plantas testadas (Chellemi, 2000). Podridão radicular observada em plantas ornamentais produzidas em viveiro também já foi associada à presença de $P$. helicoides em sistemas hidropônicos e sistemas de reciclagem de água da irrigação (Kageyama et al., 2002; Teixeira et al., 2006). Em 2013, Shrestha et al. (2013) detectaram a espécie em córregos localizados no Estado de Tennessee, EUA, confirmando a capacidade da espécie em sobreviver em ambientes aquáticos naturais.

P. myriotylum foi descrito inicialmente em plantas de tomateiro nos EUA e tem se mostrado mais agressivo sob temperaturas altas. Em testes de patogenicidade em tomateiro, a espécie foi capaz de causar podridão radicular e reduzir o tamanho das plantas (Chellemi, 2000). Em campos comerciais da Flórida (EUA), a espécie também foi isolada de lesões aquosas em folhas, pecíolos e hastes de plantas de tomateiro (Roberts et al., 1999). Atualmente o patógeno está distribuído em todo o mundo e possui uma gama de hospedeiros muito ampla, incluindo os gêneros Antirrhinum, Aponogeton, Arachis, Caladium, Citrullus, Coronilla, Cucumis, Glycine, Ligustrum, Lolium, Peperomia, Phaseolus, Robinia, Solanum e Triticum (van Der Plaats Niterink, 1981; Farr et al., 2014). No Brasil, já foi relatado em diversas culturas, como amendoim (Arachis hypogea L.), soja (Glycine max (L.) Merr.), tomate (Solanum lycopersicum L.), berinjela (Solanum melongena L.), jiló (Solanum gilo Raddi), cenoura (Daucus carota L.), batata (Solanum tuberosum L.), feijão (Phaseolus vulgaris L.) e abóbora (Cucurbita pepo L.) (Carvalho, 1965; van Der Plaats Niterink, 1981; Mendes et al, 1998). Em ambientes aquáticos, P. myriotylum foi encontrado em sistemas hidropônicos e reservatórios de água de irrigação de hortaliças (Gill, 1970; Jenkins \& Averre, 1983). 
Pythium graminicola foi encontrado pela primeira vez em raízes de trigo na Índia. No Brasil já foi encontrado em milho (Zea mays L.), cana de açúcar (Saccharum officinarum L.) e abacaxi (Ananas comosus L.) (Mendes et al. 1998; Farr, 2014). A espécie possui uma ampla gama de hospedeiros, principalmente gramíneas. Na água, a espécie foi reportada em reservatórios de água de irrigação de viveiros (Thinggaard \& Middelboe, 1989).

Pythium catenulatum é uma espécie cosmopolita e causa morte de plântulas e podridão radicular em diferentes hospedeiros, como pepino (Cucumis sativus L.), cenoura (Daucus carota L.), alface (Lactuca sativa L.), arroz (Oryza sativa L.), feijão (Phaseolus vulgaris L.), cana-de-açúcar (Saccharum officinarum L.), berinjela (Solanum melongena L.), pimentão (Cpsiacum annuum L.) e tomate (Solanum lycopersicum L.) entre outras (Frezzi, 1956; Farr, 2014). A espécie foi encontrada na água de irrigação de viveiros de plantas ornamentais e olerícolas, em reservatórios de água e canais de irrigação (Matthews, 1931; Middleton, 1943; Shokes \& McCarter, 1979; Sánchez \& Gallego, 2000)

Phytophthora macrochlamydospora foi descrita a partir de isolados encontrados em 1974 causando podridão em raízes e hastes de soja (Glycine max L. cv. Hampton) na Austrália. Atualmente a espécie é encontrada na Austrália e nos EUA (Irwin, 1991; Erwin \& Ribeiro, 1996; http://www.phytophthoradb.org/). Phytophthora quininea foi descrita originalmente no Peru como agente causal de podridão do colo e de raízes em árvores de Cinchona officinalis (Crandall, 1947). As plantas podem ser afetadas em qualquer estágio de desenvolvimento. As folhas de plantas doentes tornam-se verde pálidas e gradualmente assumem uma coloração avermelhada antes da murcha, podendo ocorrer a queda das folhas. A espécie possui distribuição geográfica limitada, sendo encontrada na Guatemala, Porto Rico, Bolívia e Peru (Erwin \& Ribeiro, 1996; http://www.phytophthoradb.org/species). 


\section{CONCLUSÕES DO CAPÍTULO}

- O sequenciamento da região ITS e a observação dos caracteres morfológicos permitiram a identificação de cinco espécies de Pythium e duas espécies de Phytophthora;

- Um total de 108 isolados não foram identificados ao nível subgenérico, demonstrando a necessidade de inclusão de outras características morfológicas e fenotípicas para cada isolado e o sequenciamento de outras regiões genômicas;

- A análise filogenética permitiu o agrupamento dos isolados de acordo com a morfologia do esporângio dentro do gênero Pythium;

- Já os isolados de Phytophthora foram agrupados com outras espécies descritas incialmente na água e que apresentam esporângios semi-papilados a não-papilados, como observado em alguns isolados;

- Apenas o isolado de Pythium helicoides causou podridão de frutos em todas as repetições testadas durante os dois experimentos. Para os demais isolados, são necessários outros testes para comprovar a patogenicidade. 


\section{REFERÊNCIAS BIBLIOGRÁFICAS}

AMORIM, L.; RESENDE, J.A.M.; BERGAMIN FILHO, A. (eds). 2011. Manual de Fitopatologia: Princípios e Conceitos. 4. ed. Volume 1 Piracicaba, SP: Ceres, 704p.

BALA, K.; ROBIDEAU, G.P.; LÉVESQUE, C.A., DE COCK, A.W.A.M; ABAD, Z.G.; LODHI, A.M.; SHAHZAD, S.; GHAFFAR, A.; COFFEY, M.D. 2010. Phytopythium Abad, de Cock, Bala, Robideau, Lodhi \& Lévesque, gen. nov. and Phytopythium sindhum Lodhi, Shahzad \& Lévesque, sp. nov. Persoonia 24, 136-137.

BLAIR, J.E.; COFFEY, M.D.; PARK, S.Y.; GEISER, D.M. \& KANG, S. 2008. A multilocus phylogeny for Phytophthora utilizing markers derived from complete genome sequences. Fungal Genetics and Biology, 45(3): 266-277.

BRASIER, C. M. 1983. Problems and prospects in Phytophthora research. In: ERWIN, D.C; BARTNICKI-GARCIA, S. \& TSAO, P.H. (Eds.). Phytophthora: Its Biology, Taxonomy, Ecology and Pathology. pp. 351-364.

BRASIER, C.M.; COOKE, D.E.L.; DUNCAN, J.M.; HANSEN, E.M. 2003. Multiple new phenotypic taxa from trees and riparian ecosystems in Phytophthora gonapodyides- $P$. megasperma ITS Clade 6, which tend to be high-temperature tolerant and either inbreeding or sterile. Mycol Res 107: 277-290.

BRIARD, M.; DUTERTRE, M.; ROUXEL, F. \& BRYGOO, Y. 1995. Ribosomal RNA sequence divergence within the Pythiaceae. Mycological Research. 99(9): 1119-1127.

CAIXETA, M. P.; CARVALHO NUNES, W. M.; SANTOS, A. F.; TESSMANN, D. J. \& VIDA, J. B. 2013. Espécies de Phytophthora associadas à gomose em pomares de citros no Estado do Paraná, Brasil. Summa Phytopathologica, 39(4): 242-247.

CARVALHO, P.D.E.C.T. DE, 1965. Occurrence in Brazil of some species of Pythium of interest to olericulture. Rickia 2: 89-106.

CHELLEMI, D.O.; MITCHELL, D.J.; KANNWISCHER-MITCHELL, M.E.; RAYSIDE, P.A. \& ROSSKOPF, E.M. 2000. Pythium spp. associated with bell pepper production in Florida. Plant Disease 84(12): 1271-1274.

COOKE, D.E.L. \& DUNCAN, J.M. 1997. Phylogenetic analysis of Phytophthora species based on ITS 1 e 2 sequences of the rDNA gene repeat. Mycological Resources, 101(6): 667677.

COOKE, D.E.L.; DRENTH, A.; DUNCAN, J.M.; WAGELS, G., \& BRASIER, C.M. 2000. A molecular phylogeny of Phytophthora and related Oomycetes. Fungal Genetics and Biology 30(1): 17-32.

CRANDALL, B.S. 1947. A new Phytophthora causing root and collar rot of cinchona in Peru. Mycologia, 218-223. 
CRAWFORD, A.R.; BASSAM, B.J.; DRENTH, A.; MACLEAN D.J. \& IRWIN, J.A.G. 1996. Evolutionary relationships among Phytophthora species deduced from rDNA sequence analysis. Mycological Research, 100(4): 437-443.

DRENTH, A. \& SENDALL, B. 2001. Practical guide to detection and identification of Phytophthora. CRC for Tropical Plant Protection, Brisbane, Australia.

ERWIN, D.C. \& RIBEIRO, O.K. 1996. Phytophthora Diseases Worldwide. APS Press, St. Paul, Minnesota.

FALEIRO, F.G. 2007. Marcadores genético-moleculares aplicados a programas de conservação e uso de recursos genéticos. Planaltina, DF: Embrapa Cerrados, 102p.

FARR, D.F., ROSSMAN, A.Y., PALM, M.E., \& MCCRAY, E.B. (n.d.) Fungal Databases, Systematic Botany \& Mycology Laboratory, ARS, USDA. http://nt.arsgrin.gov/fungaldatabases/. Consultado em: Setembro/2014.

FELINER, G.N. \& ROSSELLO, J.A., 2007. Better the devil you know? Guidelines for insightful utilization of nrDNA ITS in species-level evolutionary studies in plants. Molecular Phylogenetics and Evolution, 44(2): 911-919.

FORSTER, H.; CUMMINGS, M.P. \& COFFEY, M.D. 2000. Phylogenetic relationships of Phytophthora species based on ribosomal ITS 1 DNA sequence analysis with emphasis on Waterhouse groups V and VI. Mycological Resources, 104(9):1055-1061

FREZZI, M.J. 1956. Especies de Pythium fitopatógenas identificadas en la República Argentina. Revta Invest. agric. Buenos Aires 10: 113-241.

FUNGARO, M.H.P. 2001. PCR na Micologia: Diagnóstico e Análise de Variabilidade. Biotecnologia Ciência \& Desenvolvimento, 14: 12-16.

GAlLEGLY, M.E.; CHUANXUE, H. \& HONG, C. 2008. Phytophthora: identifying species by morphology and DNA fingerprints. American Phytopathological Society (APS Press).

GILL, D.L. 1970. Pathogenic Pythium from irrigation ponds. Plant Disease Reporter 54, 1077-1079.

HALL, T.A. 1999. BioEdit: a user-friendly biological sequence alignment editor and analysis program for Windows 95/98/NT. In: Nucleic acids symposium series. 41: 95-98.

HILLIS, D.M. \& DIXON, M.T. 1991. Ribossomal DNA: molecular evolution and phylogenetic inference. Quartely Review of Biology, 66(4): 411-453.

HONG, C.; GALLEGLY, M.E.; RICHARDSON, P.A.; KONG, P. \& MOORMAN, G.W. 2008. Phytophthora irrigata, a new species isolated from irrigation reservoirs and rivers in Eastern United States of America. FEMS microbiology letters, 285(2): 203-211.

HONG, C.X.; GALLEGLY, M.E.; RICHARDSON, P.A; KONG, P.; MOORMAN, G.W.; LEA-COX, J.D. \& ROSS, D.S. 2010. Phytophthora hydropathica, a new pathogen identified from irrigation water, Rhododendron catawbiense and Kalmia latifolia. Plant pathology, 59(5): 913-921. 
INDEX FUNGORUM. 2014. http://www.indexfungorum.org/names/names.asp. Consultado em: agosto/2014.

IRWIN, J.A.G. 1991. Phytophthora macrochlamydospora, a new species from Australia. Mycologia, 517-519.

JENKINS, S.F., \& AVERRE, C.W. 1983. Root diseases of vegetables in hydroponic culture systems in North Carolina greenhouses. Plant Disease. 67(6): 968-970.

JUNG, T.; STUKELY, M.J.C.; HARDY, G.E.S.J.; WHITE, D.; PAAP, T.; DUNSTAN, W.A. \& BURGESS, T.I. 2011 Multiple new Phytophthora species from ITS Clade 6 associated with natural ecosystems in Australia: evolutionary and ecological implications. Persoonia 26: 13-39.

KAGEYAMA, K.; AOYAGI, T.; SUNOUCHI, R. \& FUKUI, H. 2002. Root rot of miniature roses caused by Pythium helicoides. Journal of General Plant Pathology, 68(1): 15-20.

KAMMARNJESADAKUL, P.; PALAGA, T.; SRITUNYALUCKSANA, K.; MENDOZA, L.; KRAJAEJUN, T.; VANITTANAKOM, N.; TONGCHUSAK, $\quad$ S.; DENDUANGBORIPANT, J. \& CHINDAMPORN, A. 2011. Phylogenetic analysis of Pythium insidiosum Thai strains using cytochrome oxidase II (COX II) DNA coding sequences and internal transcribed spacer regions (ITS). Medical Mycology, 49(3): 289-295.

KONG, P.; HONG, C.; RICHARDSON, P.A. \& GALLEGLY, M.E. 2003. Single-strandconformational polymorphisms of ribosomal DNA for rapid species differentiation in genus Phytophthora. Fungal Genetetics Biology, 39(3): 238-249.

LÉVESQUE, C.A. \& de COCK, A.W.A.M. 2004. Molecular phylogeny and taxonomy of the genus Pythium. Mycological Research, 108(12): 1363-1383.

LIU, P.S.W. 1977. Diseases caused by Phytophthora and Pythium recorded in Sabah, Malaysia. Tech. Bull. Dep. Agric., Sabah, Malaysia. 3: 48 pp.

MAHUKU, G.S. 2004. A simple extraction method suitable for PCR-based analysis of plant, fungal, and bacterial DNA. Plant Molecular Biology Reporter, 22(1): 71-81.

MARANO, A.V.; JESUS, A.L.; DE SOUZA, J.I.; LEAÑO, E.M.; JAMES, T.Y.; JERÔNIMO, G.H.; DE COCK A.W.A.M. \& PIRES-ZOTTARELLI, C. L. A. 2014. A new combination in Phytopythium: P. kandeliae (Oomycetes, Straminipila). Mycosphere, 5(4): 510-522.

MARTIN, F.N. \& TOOLEY, P.W. 2003. Phylogenetic relationships among Phytophthora species inferred from sequence analysis of mitochondrially encoded cytochrome oxidase I and II genes. Mycologia 95(2): 269-284.

MATSUMOTO, C.; KAGEYAMA, K.; SUGA, H. \& HYAKUMACHI, M. 1999. Phylogenetic relationships of Pythium species based on ITS and 5.8S sequences of the ribosomal DNA. Mycoscience, 40(4): 321-331.

MATSUSHITA Y \& KAGEYAMA K. 2007. Root and stem rot of chrysanthemum caused by five Pythium species in Japan. J Gen Plant Pathol 73: 293-296. 
MATTHEWS, V.D. 1931. Studies on the genus Pythium. Univ. N. Carol. Press, Chapel Hill, $136 \mathrm{pp}$.

MCCARTER, S.M. \& LITTRELL, R.H. 1970. Comparative pathogenicity of Pythium aphanidermatum and Pythium myriotylum to twelve plant species and intraspecific variation in virulence. Phytopathology 60:264-268.

MCKEAN, P.G., VAUGHAN, S. \& GULL, K. 2001. The extended tubulin superfamily. Journal of cell Science, 114(15): 2723-2733.

MENDES, M.A.S.; SILVA, V.L.; DIANESE, J.C. 1998. Fungos em Plantas no Brasil. Embrapa-SPI/Embrapa-Cenargen, Brasilia, pp. 555.

MIDDLETON, J. T. 1943. The taxonomy, host range and geographic distribution of the genus Pythium. Mem. Torrey bot. Club 20: 1-171

PARK, J.; PARK, B.; VEERARAGHAVAN, N.; JUNG, K.; LEE, Y.-H.; BLAIR, J.E.; GEISER, D.M.; ISARD, S.; MANSFIELD, M.A.; NIKOLAEVA, E.; PARK, S.-Y.; RUSSO, J.; KIM, S.H.; GREENE, M.; IVORS, K.L.; BALCI, Y.; PEIMAN, M.; ERWIN, D.C.; COFFEY, M.D.; ROSSMAN, A.; FARR, D.; CLINE, E.; RÜNWALD, N.J.; LUSTER, D.G.; SCHRANDT, J.; MARTIN, F.; RIBEIRO, O.K.; MAKALOWSKA, I. \& KANG, S. 2008. Phytophthora database: a forensic database supporting the identification and monitoring of Phytophthora. Plant Disease, 92(6): 966-972.

ROBERTS, P.D. \& URS, R. 1999. First report of aerial blight caused by Pythium myriotylum on tomato in Florida. Plant Disease. 83(3):301-301.

ROBIDEAU, G.P.; DE COCK, A.W.A.M, A.; COFFEY, M.D.; VOGLMAYR, H.; BROUWER, H.; BALA, K.; CHITTY, D.W.; DÉSAULNIERS, N.; EGGERTSON, Q.A.; GACHON, C.M.M.; HU, C.; KÜPPER, F.C.; RINTOUL, T.L.; SARHAN, E.; VERSTAPPEN, E.C.P.; ZHANG, Y.; BONANTS, P.J.M.; RISTAINO, J.B. \& LÉVESQUE, C.A. 2011. DNA barcoding of oomycetes with cytochrome c oxidase subunit I and internal transcribed spacer. Molecular ecology resources, 11(6): 1002-1011.

SAITOU, N. \& NEI, M. 1987. The neighbor-joining: a new method for reconstruction phylogenetic trees. Molecular biology and evolution, 4(4):406-425.

SÁNCHEZ, J. \& GALLEGO, E. 2000. Pythium spp. present in irrigation water in the Poniente region of Almeria (south-eastern Spain). Mycopathologia 150:29-38.

SCHROEDER, K.L.; MARTIN, F.N.; DE COCK, A.W.; LÉVÉSQUE, C.A; SPIES, C.F.; OKUBARA, P.A. \& PAULITZ, T.C. 2013. Molecular detection and quantification of Pythium species: evolving taxonomy, new tools, and challenges. Plant Disease, 97(1): 4-20.

SCOTT, P.T.; MARTIN, H.L.; BOREEL, S.M.; WEARING, A.H. \& MACLEAN, D.J. 2005. Molecular characterisation, pathogenesis and fungicide sensitivity of Pythium spp. from table beet (Beta vulgaris var. vulgaris) grown in the Lockyer Valley, Queensland. Australas. Plant Pathology. 34(3): 361-368.

SHOKES, F.F. \& MCCARTER, S.M. 1979. Occurrence, dissemination, and survival of plant pathogens in surface irrigation ponds in southern Georgia. Phytopathology 69: 510-516. 
SHRESTHA, S.K. 2012. Investigation of Phytophthora species: Phytophthora colocasiae on Taro and Phytophthora Recovered from Streams in Eastern Tennessee. Thesis of master. University of Tennessee, Knoxville. Tennessee, EUA.

SHRESTHA, S.K.; ZHOU, Y., LAMOUR, K.H. 2013. Oomycetes baited from streams in Tennessee 2010-2012. Mycologia 105(6): 1516-23

STAMPS, D. J.; WATERHOUSE, G. M.; NEWHOOK, F. J. \& HALL, G. S. 1990. Revised tabular key to the species of Phytophthora. No. Ed. 2. Wallingford CAB International.

TAKAHASHI, M; ICHITANI, T. \& SASAKI, M. 1977. Pythium porphyrae Takahashi et Sasaki, sp. nov. causing red rot of marine red algae Porphyra spp. Trans Mycol Soc Jpn 18:279-285

TEIXEIRA, L.D.D.; PIRES-ZOTTARELLI, C.L.A.P. \& KIMATI, H. 2006. Efeito da temperatura no crescimento micelial e patogenicidade de Pythium spp. que ocorrem em alface hidropônica. Summa Phytopathologica, 32, 221-226.

THINGGAARD, K. \& MIDDELBOE, A.L. 1989. Phytophthora and Pythium in pot plant cultures grown on ebb and flow bench with recirculating nutrient solution. Journal of Phytopathology 125(4): 343-352.

UZUHASHI, S.; TOJO, M. \& KAKISHIMA, M. 2010. Phylogeny of the genus Pythium and description of new genera. Mycoscience, 51(5): 337-365.

VAN DER PLAATS-NITERINK, A.J. 1981. Monograph of the genus Pythium. Studies in Mycology. No.21. Centraalbureau voor Schimmelcultures, Baarn. 242 pp.

VILLA, N.O.; KAGEYAMA, K.; ASANO, T.; SUGA, H.; 2006. Phylogenetic relationships of Pythium and Phytophthora species based on ITS rDNA, cytochrome oxidase II and betatubulin sequences. Mycologia 98, 410-422.

WANG, P.H.; WANG, Y.T. \& WHITE, J.G. 2003. Species-specific PCR primers for Pythium developed from ribosomal ITS1 region. Lett. Appl. Microbiol. 37:127-132.

WATANABE, H.; HORINOUCHI, H.; TANAHASHI, I. \& KAGEYAMA, K. 2005. Occurrence of root rot of strawberry caused by Pythium helicoides, and pathogenicity to several crop (abstract in Japanese). Jpn J Phytopathol 71: 209-210.

WATERHOUSE, G. M. 1963. Key to the species of Phytophthora de Bary. Mycology Paper No. 92, 22 pp. CMI Kew, UK.

WATERHOUSE, G.M. 1968. The genus Pythium Pringsheim. Mycol. Pap. 110:1-71.

WATERHOUSE, G.M. 1970. The genus Phytophthora de Bary. Diagnoses (or descriptions) and figures from the original papers. Kew Commonweath Mycological Institute. Mycological Papers 122.

WHITE, T.J.; BRUNS, T.; LEE, S. \& Taylor, J.. 1990. Amplification and direcr sequencing of fungal ribossomal RNA genes for phylogenetics. In: INNIS, M.A.; GELFAND, D.H.; SNINSKY, J.J.; WHITE, T.J. eds. PCR Protocols: a guide to methods and applications. San Diego: Academic Press. p.315-322. 
YANG, X. \& HONG, C. 2013. Phytophthora virginiana sp. nov., a high-temperature tolerant species from irrigation water in Virginia. Mycotaxon, 126(1), 167-176.

YANG, X., RICHARDSON, P. A. \& HONG, C. 2014. Phytophthorax stagnum nothosp. nov., a New Hybrid from Irrigation Reservoirs at Ornamental Plant Nurseries in Virginia. PloS one, 9(7): e103450 


\section{CONSIDERAÇÕES FINAIS}

Este estudo traz uma contribuição para o conhecimento das espécies de Pythium e Phytophthora que ocorrem em ambientes aquáticos naturais e em agroecossistemas do Centro-Oeste do Brasil e apresenta relevância na compreensão dos fatores que afetam a distribuição de oomicetos na água. Além disso, comprova que o uso de folhas que são facilmente encontradas pode ser uma ferramenta útil e prática no monitoramento destes fitopatógenos em corpos d'água.

Apesar de vários trabalhos terem comprovado a existência de oomicetos em fontes de água de irrigação, ainda se sabe pouco sobre a sobrevivência e a reprodução destes microrganismos em ecossistemas aquáticos. A capacidade de disseminação através da irrigação e a patogenicidade dos isolados encontrados também tem sido pouco estudada ao longo dos anos. Desta forma, levantamentos da diversidade em diferentes fontes de água sob diferentes condições se constituem no passo inicial para o entendimento dos fatores que influenciam a dinâmica populacional e podem auxiliar estudos futuros que objetivem elucidar os mecanismos de persistência e dispersão de propágulos de fitopátogenos na água, a capacidade dessas espécies em tolerar ambientes terrestres e compreender a epidemiologia de doenças causadas por oomicetos aquáticos.

Assim, outros estudos visando complementar o conhecimento sobre a ocorrência de espécies fitopatogênicas em fontes de água de irrigação, seu potencial como agentes causais de doenças de plantas e o impacto econômico que essas espécies podem gerar na agricultura devem ser consuzidos. 